\title{
Regioselective Acylation of Diols and Triols: The Cyanide Effect
}

\author{
Peng Peng, Michael Linseis, Rainer Winter, Richard R. Schmidt* \\ Department of Chemistry, University of Konstanz, D-78457 Konstanz, Germany \\ E-mail: Richard.schmidt@,uni-konstanz.de
}

\section{Table of Contents}

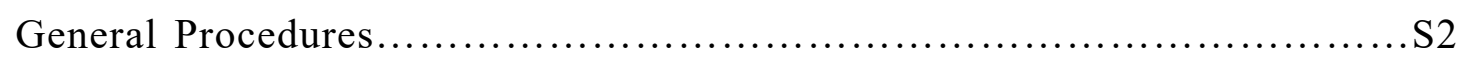

Procedures for DMAP catalyzed cyanide-mediated regioselective benzoylation of diols S2-S9

Procedures for DMAP catalyzed regioselectively benzoylation with $\mathrm{Bz}_{2} \mathrm{O}$ or $\mathrm{BzF}$ as reagent. S9-S10

Procedure for TBACN promoted cyanide-mediated selectively benzoylation with $\mathrm{Bz}_{2} \mathrm{O}$ or $\mathrm{BzF}$ as reagent.

Procedures for DMAP catalyzed cyanide-mediated regioselective acetylation of diols. S10-S14

Procedures for DMAP catalyzed cyanide-mediated regioselective benzoylation of triols. . . S14-S16

Figure RW-1: IRC-scans for the incremental decrease of the respective $\mathrm{H}-\mathrm{X} / \mathrm{Y}$ coordinate.

Figure RW-2: IRC-scans for the incremental decrease of the respective $\mathrm{H}$-C-coordinate for the $\mathbf{2}_{\text {ax }}, \mathbf{3}_{\text {eq }}-\mathbf{N}$ to $\mathbf{2}_{\text {ax }}, \mathbf{3}_{\text {eq }}-\mathbf{C}$ conversion over a $\mathbf{2}_{\text {ax }}-\mathbf{C} / \mathbf{3}_{\text {eq }}-\mathbf{N}$ transition state..... S18

Coordinates of computationally optimized structures S19-S29

Copies of NMR Spectra for the new compounds S30-S98 


\section{Experimental Section}

\section{General Procedures}

All reagents and solvents were dried prior to use according to standard methods. Commercial reagents were used without further purification, unless otherwise stated. ${ }^{1} \mathrm{H}$ NMR spectra were recorded on an Advance DRX Bruker-400 MHz spectrometer at $25^{\circ} \mathrm{C}$. High-resolution mass spectrometry was performed on a Bruker APEX IV. All reactions were performed in flame-dried modified Schlenk (Kjeldahl shape) flasks fitted with a glass stopper or rubber septa under a positive pressure of argon and away from light. Analytical TLC was performed on silica gel 60-F254 precoated on aluminum plates (E. Merck), with detection by fluorescence and/or by staining with acidic ceric ammonium molybdate. Column chromatograp-hy was performed employing Silica Gel 230-400 mesh.

\section{Procedures for DMAP catalyzed cyanide-mediated regioselective benzoylation} of diols:

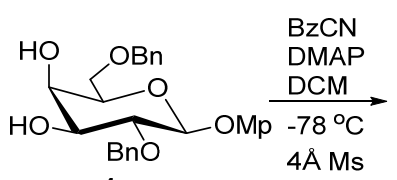

1 a

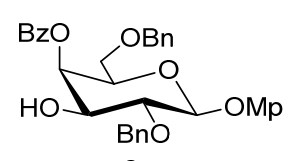

2a

\section{4-Methoxyphenyl 4-O-benzoyl-2,6-di-O-benzyl- $\beta$-D-galactopyranoside (2a)}

To a solution of compound $\mathbf{1 a}(33 \mathrm{mg}, 70.8 \mu \mathrm{mol})$ and $4 \AA$ molecular sieves in $3 \mathrm{~mL}$ of dry DCM was added benzoyl cyanide $(10.0 \mathrm{mg}, 76.3 \mu \mathrm{mol})$ at room temperature under nitrogen atmosphere. After cooling down the reaction mixture to $-78{ }^{\circ} \mathrm{C}$, 4dimethylaminopyridine (DMAP) $(1 \mathrm{mg}, 7.1 \mu \mathrm{mol})$ was added. The reaction was further stirred for $4 \mathrm{~h}$ at this temperature. After the TLC analysis showed the reaction was complete, the reaction was quenched by addition of $\mathrm{NH}_{4} \mathrm{Cl}(\mathrm{aq})$ and $100 \mu \mathrm{L} \mathrm{MeOH}$. Then the mixture was diluted with $100 \mathrm{~mL}$ of DCM and the precipitate was filtered off through a pad of Celite. The organic layer was washed with $\mathrm{NH}_{4} \mathrm{Cl}$ (aq) and $\mathrm{Na}_{2} \mathrm{~S}_{2} \mathrm{O}_{3}$ (aq), dried over $\mathrm{Na}_{2} \mathrm{SO}_{4}$, filtered, and concentrated. The residue was purified by column chromatography (hexane/ethyl acetate $=3: 1$ ) on silica gel to afford compound $\mathbf{2 a}^{\mathbf{1}}$ (36.2 $\mathrm{mg}, 90 \%$ ) as white solid.

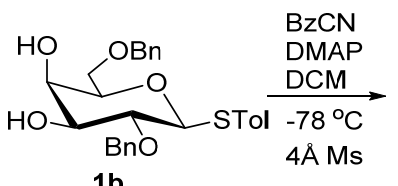

$1 \mathrm{~b}$

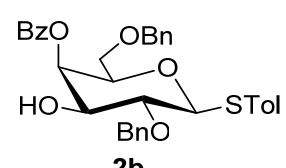

2b

4-Methylphenyl 4-O-benzoyl-2,6-di-O-benzyl-1-thio- $\beta$-D-galactopyranoside (2b) 
To a solution of compound $\mathbf{1 b}(50 \mathrm{mg}, 107.3 \mu \mathrm{mol})$ and $4 \AA$ molecular sieves in $3 \mathrm{~mL}$ of dry DCM was added benzoyl cyanide $(15.0 \mathrm{mg}, 114.5 \mu \mathrm{mol})$ at room temperature under nitrogen atmosphere. After cooling down the reaction mixture to $-78{ }^{\circ} \mathrm{C}$, 4dimethylaminopyridine (DMAP) $(1.3 \mathrm{mg}, 11.1 \mu \mathrm{mol})$ was added. The reaction was further stirred for $4 \mathrm{~h}$ at this temperature. After the TLC analysis showed the reaction was complete, the reaction was quenched by addition of $\mathrm{NH}_{4} \mathrm{Cl}(\mathrm{aq})$ and $100 \mu \mathrm{L} \mathrm{MeOH}$. Then the mixture was diluted with $100 \mathrm{~mL}$ of DCM and the precipitate was filtered off through a pad of Celite. The organic layer was washed with $\mathrm{NH}_{4} \mathrm{Cl}$ (aq) and $\mathrm{Na}_{2} \mathrm{~S}_{2} \mathrm{O}_{3}$ (aq), dried over $\mathrm{Na}_{2} \mathrm{SO}_{4}$, filtered, and concentrated. The residue was purified by column chromatography (hexane/ethyl acetate $=3: 1)$ on silica gel to afford compound $\mathbf{2 b}(53.8$ mg, $88 \%$ ) as white solid. ${ }^{1} \mathrm{H}$ NMR (400 MHz, $\left.\mathrm{CDCl}_{3}\right) \delta=7.87-7.96(\mathrm{~m}, 2 \mathrm{H}, \mathrm{ArH})$, 7.50-7.56 (m, 1H, ArH), 7.47 (d, 2H, J=7.9 Hz, ArH), 7.33-7.40 (m, 2H, ArH), 7.287.34 (m, 2H, ArH), 7.09-7.27 (m, 8H, ArH), 7.03 (d, 2H, J=7.9 Hz, ArH), 5.56 (d, 1H, $\mathrm{J}=3.2 \mathrm{~Hz}, 4-\mathrm{H}), 4.84$ (d, 1H, J=10.8 Hz, $\mathrm{PhCH}_{2}$ ), 4.60 (d, 1H, J=10.8 Hz, $\mathrm{PhCH}_{2}$ ), 4.57 (d, 1H, $J=10.0 \mathrm{~Hz}, 1-\mathrm{H}), 4.42$ (d, 1H, $\left.J=11.8 \mathrm{~Hz}, \mathrm{PhCH}_{2}\right), 4.34$ (d, 1H, $J=11.8$ $\mathrm{Hz}, \mathrm{PhCH}_{2}$ ), 3.84-3.94 (m, 1H, 5-H), 3.75-3.94 (m, 2H, 3-H, 5-H), 3.42-3.69 (m, 3H, 2-H, 6a-H, 6b-H), 2.36 (1H, bs, OH), 2.28 (s, 3H, PhMe). ${ }^{13} \mathrm{C} \mathrm{NMR}\left(101 \mathrm{MHz}, \mathrm{CDCl}_{3}\right)$ $\delta=166.46,138.04,137.78,137.68,133.29,132.87,130.02,129.67,129.53,129.40$, $128.49,128.35,128.31,128.18,127.97,127.77,127.66,87.36,77.81,77.08,76.39$, $75.35,74.35,73.60,70.88,68.42,21.19$. HRMS (ESI) Calcd for $\mathrm{C}_{34} \mathrm{H}_{38} \mathrm{NO}_{6} \mathrm{~S}[\mathrm{M}+$ $\left.\mathrm{NH}_{4}\right]^{+}:$588.2414, found: 588.2416 .

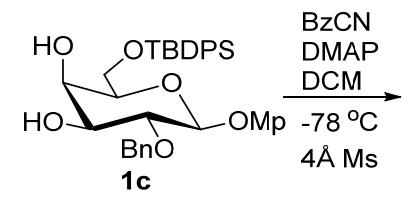

\section{4-Methoxyphenyl}

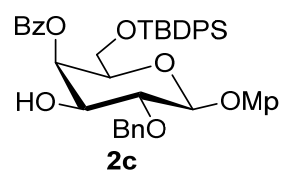

4-O-benzoyl-2-O-benzyl-6-O-tert-butyldiphenylsilyl- $\beta$-Dgalactopyranoside (2c)

To a solution of compound $1 \mathrm{c}(60 \mathrm{mg}, 97.7 \mu \mathrm{mol})$ and $4 \AA$ molecular sieves in $3 \mathrm{~mL}$ of dry DCM was added benzoyl cyanide $(14.0 \mathrm{mg}, 107.5 \mu \mathrm{mol})$ at room temperature under nitrogen atmosphere. After cooling down the reaction mixture to $-78{ }^{\circ} \mathrm{C}$, 4dimethylaminopyridine (DMAP) $(1.2 \mathrm{mg}, 10.0 \mu \mathrm{mol})$ was added. The reaction was further stirred for $4 \mathrm{~h}$ at this temperature. After the TLC analysis showed the reaction was complete, the reaction was quenched by addition of $\mathrm{NH}_{4} \mathrm{Cl}$ (aq) and $100 \mu \mathrm{L} \mathrm{MeOH}$. Then the mixture was diluted with $100 \mathrm{~mL}$ of DCM and the precipitate was filtered off through a pad of Celite. The organic layer was washed with $\mathrm{NH}_{4} \mathrm{Cl}$ (aq) and $\mathrm{Na}_{2} \mathrm{~S}_{2} \mathrm{O}_{3}$ (aq), dried over $\mathrm{Na}_{2} \mathrm{SO}_{4}$, filtered, and concentrated. The residue was purified by column chromatography (hexane/ethyl acetate $=4: 1)$ on silica gel to afford compound $2 \mathrm{c}(61.2$ mg, 87\%) as semisolid. ${ }^{1} \mathrm{H}$ NMR (400 MHz, $\left.\mathrm{CDCl}_{3}\right) \delta=7.93-8.01$ (m, 2H, ArH), 7.47- 
7.57 (m, 3H, ArH), 7.42-7.47 (m, 2H, ArH), 7.14-7.40 (m, 11H, ArH), 7.07 (t, 2H, $J=$ $7.5 \mathrm{~Hz}, \operatorname{ArH}), 6.90-6.99$ (m, 2H, ArH), 6.58-6.77 (m, 2H, ArH), 5.65 (d, 1H, J=3.6 Hz, 4-H), 4.98 (d, 1H, $\left.J=11.2 \mathrm{~Hz}, \mathrm{PhCH}_{2}\right), 4.85$ (d, 1H, $\left.J=7.6 \mathrm{~Hz}, 1-\mathrm{H}\right), 4.71$ (d, 1H, $J=$ 11.2 Hz, $\mathrm{PhCH}_{2}$ ), 2.37-2.52 (m, 1H, 3-H), 3.69-3.81 (m, 4H, 2-H, 5-H, 6-H, 6'-H), 3.67 (s, 3H, OMe), 2.48 (d, 1H, $J=2.8 \mathrm{~Hz}, \mathrm{OH}), 0.94$ (s, 9H, tert-Butyl). ${ }^{13} \mathrm{C}$ NMR (100 $\left.\mathrm{MHz}, \mathrm{CDCl}_{3}\right) \delta=166.31,155.36,151.41,138.09,135.53,135.45,133.15,132.97$, $132.70,130.03,129.70,129.67,128.48,128.35,128.13,127.90,127.69,127.61,118.29$, $114.59,102.91,79.29,75.07,74.16,72.55,69.71,61.90,55.63,26.71,19.03$. HRMS (ESI) Calcd for $\mathrm{C}_{43} \mathrm{H}_{50} \mathrm{NO}_{8} \mathrm{Si}\left[\mathrm{M}+\mathrm{NH}_{4}\right]^{+}:$736.3300, found: 736.3312 .



\section{4-Methoxyphenyl 2,4,6-tri-O-benzoyl- $\beta$-D-galactopyranoside (2d)}

To a solution of compound $\mathbf{1 d}(30 \mathrm{mg}, 60.7 \mu \mathrm{mol})$ and $4 \AA$ molecular sieves in $3 \mathrm{~mL}$ of dry DCM was added benzoyl cyanide $(8.0 \mathrm{mg}, 61.1 \mu \mathrm{mol})$ at room temperature under nitrogen atmosphere. After cooling down the reaction mixture to $-78{ }^{\circ} \mathrm{C}$, 4dimethylaminopyridine (DMAP) $(1 \mathrm{mg}, 8.2 \mu \mathrm{mol})$ was added. The reaction was further stirred for $4 \mathrm{~h}$ at this temperature. After the TLC analysis showed the reaction was complete, the reaction was quenched by addition of $\mathrm{NH}_{4} \mathrm{Cl}(\mathrm{aq})$ and $100 \mu \mathrm{L} \mathrm{MeOH}$. Then the mixture was diluted with $100 \mathrm{~mL}$ of DCM and the precipitate was filtered off through a pad of Celite. The organic layer was washed with $\mathrm{NH}_{4} \mathrm{Cl}$ (aq) and $\mathrm{Na}_{2} \mathrm{~S}_{2} \mathrm{O}_{3}$ (aq), dried over $\mathrm{Na}_{2} \mathrm{SO}_{4}$, filtered, and concentrated. The residue was purified by column chromatography (hexane/ethyl acetate $=3: 1$ ) on silica gel to afford compound $\mathbf{2} \mathbf{d}^{\mathbf{2}}$ (32.3 $\mathrm{mg}, 89 \%)$ as white solid .
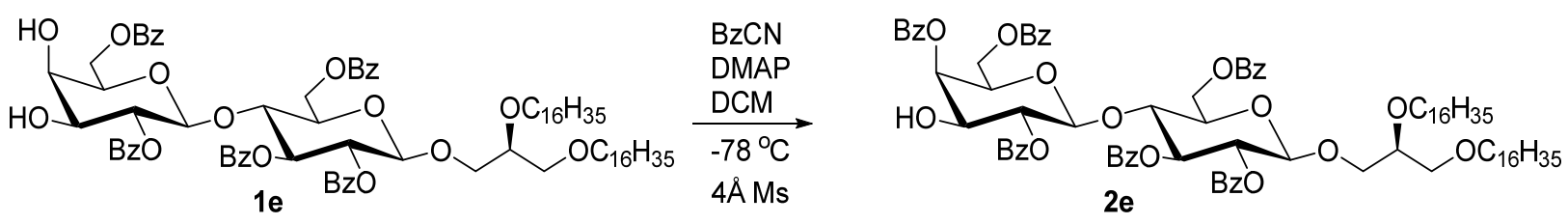

(2R)-2,3-Di-hexadecyloxypropyl 2,4,6-tri-O-benzoyl- $\beta$-D-galactopyranosyl$(1 \rightarrow 4)-2,3,6$-tri-O-benzoyl- $\beta$-D-glucopyranoside (2e)

To a solution of compound 1e (100 mg, $72.2 \mu \mathrm{mol})$ and $4 \AA$ molecular sieves in $3 \mathrm{~mL}$ of dry DCM was added benzoyl cyanide $(10.0 \mathrm{mg}, 76.3 \mu \mathrm{mol})$ at room temperature under nitrogen atmosphere. After cooling down the reaction mixture to $-78{ }^{\circ} \mathrm{C}$, 4dimethylaminopyridine (DMAP) ( $1 \mathrm{mg}, 8.2 \mu \mathrm{mol}$ ) was added. The reaction was further stirred for $4 \mathrm{~h}$ at this temperature. After the TLC analysis showed the reaction was complete, the reaction was quenched by addition of $\mathrm{NH}_{4} \mathrm{Cl}(\mathrm{aq})$ and $100 \mu \mathrm{L} \mathrm{MeOH}$. 
Then the mixture was diluted with $100 \mathrm{~mL}$ of DCM and the precipitate was filtered off through a pad of Celite. The organic layer was washed with $\mathrm{NH}_{4} \mathrm{Cl}$ (aq) and $\mathrm{Na}_{2} \mathrm{~S}_{2} \mathrm{O}_{3}$ (aq), dried over $\mathrm{Na}_{2} \mathrm{SO}_{4}$, filtered, and concentrated. The residue was purified by column chromatography (hexane/ethyl acetate $=3: 1)$ on silica gel to afford compound $2 \mathbf{e}(97.2$ mg, 90\%) as semisolid. ${ }^{1} \mathrm{H}$ NMR (400 MHz, $\left.\mathrm{CDCl}_{3}\right) \delta=7.95-8.01(\mathrm{~m}, 4 \mathrm{H}, \mathrm{ArH}), 7.85-$ 7.93 (m, 6H, ArH), 7.82 (d, 2H, J = 7.7 Hz, ArH), 7.49-7.52 (m, 2H, ArH), 7.34-7.48 (m, 7H, ArH), 7.24-7.31 (m, 6H, ArH), 7.16-7.20 (m, 2H, ArH), 6.94 (t, 2H, J = 7.7 Hz, $\operatorname{ArH}), 5.66(\mathrm{t}, 1 \mathrm{H}, \mathrm{J}=9.6 \mathrm{~Hz}, 3 \mathrm{a}-\mathrm{H}), 5.39(\mathrm{~d}, 1 \mathrm{H}, J=3.2 \mathrm{~Hz}, 4 \mathrm{~b}-\mathrm{H}), 5.38$ (dd, 1H, $J=$ 8.0, 10.0 Hz, 2b-H), 5.23 (dd, 1H, J=7.8, 10.0 Hz, 2a-H), 4.69(d, 1H, J=8.0 Hz, 1bH), 4.65(d, 1H, J = 7.8 Hz, 1a-H), 4.38-4.57 (m, 2H, 6a-H, 6a'-H), 4.11 (t, 1H , J = 9.6 $\mathrm{Hz}, 4 \mathrm{a}-\mathrm{H}), 3.81-3.90$ (m, 1H, 3b-H), 3.73-3.79 (m, 2H, 5a-H), 3.70 (dd, 1H, J = 5.9, $11.2 \mathrm{~Hz}, 6 \mathrm{~b}-\mathrm{H}), 3.63(\mathrm{t}, 1 \mathrm{H}, J=6.4 \mathrm{~Hz}), 3.50(\mathrm{dd}, 1 \mathrm{H}, J=5.9,10.5 \mathrm{~Hz}), 3.34-3.43(\mathrm{~m}$, $\left.2 \mathrm{H}, 6 \mathrm{~b}^{\prime}-\mathrm{H}\right), 3.27-3.34$ (m, 2H), 3.24 (dd, $\left.1 \mathrm{H}, J=4.3,10.4 \mathrm{~Hz}\right), 3.16$ (dd, $1 \mathrm{H}, J=5.4$, $10.3 \mathrm{~Hz}), 2.95-3.09(\mathrm{~m} 2 \mathrm{H}), 2.69(\mathrm{~d}, 1 \mathrm{H}, J=6.2 \mathrm{~Hz}, \mathrm{OH}), 1.01-1.35(\mathrm{~m}, 56 \mathrm{H}), 0.80$ (t, $6 \mathrm{H}, J=6.7 \mathrm{~Hz}) .{ }^{13} \mathrm{C} \mathrm{NMR}\left(101 \mathrm{MHz}, \mathrm{CDCl}_{3}\right) \delta=166.36,165.96,165.76,165.60$, $165.42,165.04,133.47,133.43,133.34,133.30,133.06,132.93,130.03,129.82$, $129.75,129.61,129.59,129.50,129.36,128.91,128.86,128.61,128.52,128.49$, $128.25,128.00,101.35,100.56,75.93,73.67,73.00,72.74,71.81,71.69,71.56,71.45$, 70.44, 70.10, 70.03, 68.94, 62.68, 61.52, 31.88, 29.92, 29.66, 29.64, 29.61, 29.60, 29.57, 29.55, 29.47, 29.40, 29.31, 25.95, 25.92, 22.64, 14.06. HRMS (ESI) Calcd for $\mathrm{C}_{89} \mathrm{H}_{120} \mathrm{NO}_{19}\left[\mathrm{M}+\mathrm{NH}_{4}\right]^{+}: 1506.8449$, found: 1506.8465 .

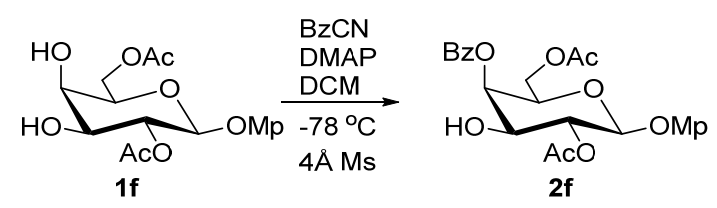

\section{4-Methoxyphenyl 2,6-di-O-acetyl-4-O-benzoyl- $\beta$-D-galactopyranoside (2f)}

To a solution of compound $\mathbf{1 f}(35 \mathrm{mg}, 94.6 \mu \mathrm{mol})$ and $4 \AA$ molecular sieves in $3 \mathrm{~mL}$ of mixture dry DCM/MeCN (2:1) was added benzoyl cyanide $(13.0 \mathrm{mg}, 99.2 \mu \mathrm{mol})$ at room temperature under nitrogen atmosphere. After cooling down the reaction mixture to $-78^{\circ} \mathrm{C}$, 4-dimethylaminopyridine (DMAP) $(1 \mathrm{mg}, 8.2 \mu \mathrm{mol})$ was added. The reaction was further stirred for $4 \mathrm{~h}$ at this temperature. After the TLC analysis showed the reaction was complete, the reaction was quenched by addition of $\mathrm{NH}_{4} \mathrm{Cl}$ (aq) and 100 $\mu \mathrm{L} \mathrm{MeOH}$. Then the mixture was diluted with $100 \mathrm{~mL}$ of DCM and the precipitate was filtered off through a pad of Celite. The organic layer was washed with $\mathrm{NH}_{4} \mathrm{Cl}$ (aq) and $\mathrm{Na}_{2} \mathrm{~S}_{2} \mathrm{O}_{3}$ (aq), dried over $\mathrm{Na}_{2} \mathrm{SO}_{4}$, filtered, and concentrated. The residue was purified by column chromatography (hexane/ethyl acetate $=3: 1$ ) on silica gel to afford compound $2 \mathbf{f}$ (41.5 mg, 92\%) as semisolid. ${ }^{1} \mathrm{H}$ NMR (400 $\left.\mathrm{MHz}, \mathrm{CDCl}_{3}\right) \delta=7.97-8.08$ (m, 2H, ArH), 7.50-7.57 (m, 1H, ArH), 7.40 (t, 2H, J=7.8 Hz, ArH), 6.86-6.97 (m, 2H, 
ArH), 6.71-6.81 (m, 2H, ArH), 5.57 (dd, $1 \mathrm{H}, J=1.1,3.6 \mathrm{~Hz}, 4-\mathrm{H}), 5.25$ (dd, 1H, $J=$ 8.0, 10.1 Hz, 2-H), 4.87 (d, 1H, J = 8.0 Hz, 1-H), 4.11-4.23 (m, 2H, 6-H, 6'-H), 3.894.01 (m, 2H, 3-H, 5-H), 3.71 (s, 3H, OMe), 2.61 (d, 1H, J = 6.5 Hz, OH), 2.08 (s, 3H, OAc), $1.96(\mathrm{~s}, 3 \mathrm{H}, \mathrm{OAc}) .{ }^{13} \mathrm{C} \mathrm{NMR}\left(101 \mathrm{MHz}, \mathrm{CDCl}_{3}\right) \delta=171.05,170.43,166.24$, 155.72, 151.11, 133.70, 130.10, 128.88, 128.60, 118.66, 114.56, 100.53, 72.66, 71.72, 71.52, 70.20, 62.20, 55.67, 20.91, 20.64. HRMS (ESI) Calcd for $\mathrm{C}_{23} \mathrm{H}_{27} \mathrm{O}_{6}[\mathrm{M}+\mathrm{H}]^{+}$: 399.1802, found:399.1800; $\mathrm{C}_{24} \mathrm{H}_{30} \mathrm{NO}_{10}\left[\mathrm{M}+\mathrm{NH}_{4}\right]^{+}:$492.1864, found:492.1863.

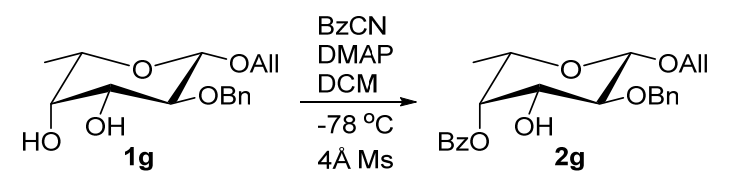

\section{Allyl 4-O-benzoyl-2-O-benzyl- $\beta$-L-fucopyranoside (2g)}

To a solution of compound $\mathbf{1 g}$ (40 mg, $136.1 \mu \mathrm{mol})$ and $4 \AA$ molecular sieves in $3 \mathrm{~mL}$ of dry DCM was added benzoyl cyanide $(19.0 \mathrm{mg}, 145.0 \mu \mathrm{mol})$ at room temperature under nitrogen atmosphere. After cooling down the reaction mixture to $-78{ }^{\circ} \mathrm{C}$, 4dimethylaminopyridine (DMAP) $(1.6 \mathrm{mg}, 13.6 \mu \mathrm{mol})$ was added. The reaction was further stirred for $4 \mathrm{~h}$ at this temperature. After the TLC analysis showed the reaction was complete, the reaction was quenched by addition of $\mathrm{NH}_{4} \mathrm{Cl}$ (aq) and $100 \mu \mathrm{L} \mathrm{MeOH}$. Then the mixture was diluted with $100 \mathrm{~mL}$ of DCM and the precipitate was filtered off through a pad of Celite. The organic layer was washed with $\mathrm{NH}_{4} \mathrm{Cl}$ (aq) and $\mathrm{Na}_{2} \mathrm{~S}_{2} \mathrm{O}_{3}$ (aq), dried over $\mathrm{Na}_{2} \mathrm{SO}_{4}$, filtered, and concentrated. The residue was purified by column chromatography (hexane/ethyl acetate $=3: 1)$ on silica gel to afford compound $\mathbf{2 g}$ (46.5 mg, 86\%) as semisolid. ${ }^{1} \mathrm{H}$ NMR (400 MHz, $\left.\mathrm{CDCl}_{3}\right) \delta=7.97-8.05(\mathrm{~m}, 2 \mathrm{H}, \mathrm{ArH}), 7.45-$ 7.57 (m, 1H, ArH), 7.34-7.42 (m, 2H, ArH), 7.15-7.32 (m, 6H, ArH), 5.86-5.99 (m, 1H, $\left.-\mathrm{CH}_{2} \mathrm{CH}=\mathrm{CH}_{2}\right), 5.34(\mathrm{~d}, 1 \mathrm{H}, \mathrm{J}=3.6 \mathrm{~Hz}, 4-\mathrm{H}), 5.25-5.33\left(\mathrm{~m}, 1 \mathrm{H},-\mathrm{CH}_{2} \mathrm{CH}=\mathrm{CH}_{2}\right), 5.12-$ $5.19\left(\mathrm{~m}, 1 \mathrm{H},-\mathrm{CH}_{2} \mathrm{CH}=\mathrm{CH}_{2}\right), 4.95\left(\mathrm{~d}, 1 \mathrm{H}, J=11.2 \mathrm{~Hz}, \mathrm{PhCH}_{2}\right), 4.63(\mathrm{~d}, 1 \mathrm{H}, J=11.2$ $\left.\mathrm{Hz}, \mathrm{PhCH}_{2}\right), 4.16$ (d, $\left.1 \mathrm{H}, J=8.0 \mathrm{~Hz}, 1-\mathrm{H}\right), 4.38-4.43$ (m, $\left.1 \mathrm{H},-\mathrm{CH}_{2} \mathrm{CH}=\mathrm{CH}_{2}\right), 4.06-$ $4.17\left(\mathrm{~m}, 1 \mathrm{H},-\mathrm{CH}_{2} \mathrm{CH}=\mathrm{CH}_{2}\right), 3.78(\mathrm{dd}, 1 \mathrm{H}, J=3.6,9.7 \mathrm{~Hz}, 3-\mathrm{H}), 3.73(\mathrm{qd}, 1 \mathrm{H}, J=1.2$, $6.5 \mathrm{~Hz}, 5-\mathrm{H}), 3.55$ (dd, 1H, J=7.7, $9.7 \mathrm{~Hz}, 2-\mathrm{H}), 2.29$ (s, 1H, OH), 1.18 (d, 3H, J = 6.5 $\mathrm{Hz}, \mathrm{Me}) .{ }^{13} \mathrm{C} \mathrm{NMR}\left(100 \mathrm{MHz}, \mathrm{CDCl}_{3}\right) \delta=166.57,138.26,133.96,133.15,130.02$, $129.65,128.47,128.37,128.33,128.16,127.87,117.50,102.65,79.05,74.74,72.75$, 72.20, 70.42, 69.61, 16.39. HRMS (ESI) Calcd for $\mathrm{C}_{23} \mathrm{H}_{27} \mathrm{O}_{6}[\mathrm{M}+\mathrm{H}]^{+}:$399.1802, found:399.1800; $\mathrm{C}_{23} \mathrm{H}_{30} \mathrm{NO}_{6}\left[\mathrm{M}+\mathrm{NH}_{4}\right]^{+}:$416.2068, found: 416.2064.

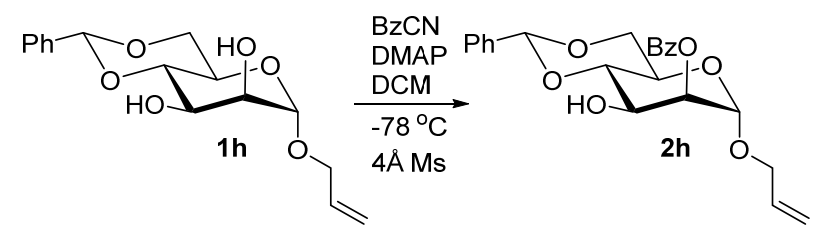




\section{Allyl 2-O-benzoyl-4,6-O-benzylidene- $\alpha$-D-mannopyranoside (2h)}

To a solution of compound $\mathbf{1 h}(25 \mathrm{mg}, 81.2 \mu \mathrm{mol})$ and $4 \AA$ molecular sieves in $3 \mathrm{~mL}$ of dry DCM was added benzoyl cyanide $(11.0 \mathrm{mg}, 84.0 \mu \mathrm{mol})$ at room temperature under nitrogen atmosphere. After cooling down the reaction mixture to $-78{ }^{\circ} \mathrm{C}$, 4dimethylaminopyridine (DMAP) $(1 \mathrm{mg}, 8.2 \mu \mathrm{mol})$ was added. The reaction was further stirred for $4 \mathrm{~h}$ at this temperature. After the TLC analysis showed the reaction was complete, the reaction was quenched by addition of $\mathrm{NH}_{4} \mathrm{Cl}(\mathrm{aq})$ and $100 \mu \mathrm{L} \mathrm{MeOH}$. Then the mixture was diluted with $100 \mathrm{~mL}$ of DCM and the precipitate was filtered off through a pad of Celite. The organic layer was washed with $\mathrm{NH}_{4} \mathrm{Cl}$ (aq) and $\mathrm{Na}_{2} \mathrm{~S}_{2} \mathrm{O}_{3}$ (aq), dried over $\mathrm{Na}_{2} \mathrm{SO}_{4}$, filtered, and concentrated. The residue was purified by column chromatography (hexane/ethyl acetate $=3: 1)$ on silica gel to afford compound $\mathbf{2 h}(28.5$ mg, 85\%) as white solid. ${ }^{1} \mathrm{H}$ NMR (400 MHz, $\left.\mathrm{CDCl}_{3}\right) \delta=7.91-8.12(\mathrm{~m}, 2 \mathrm{H}, \mathrm{ArH})$, 7.48-7.58 (m, 1H, ArH), 7.35-7.45 (m, 4H, ArH), 7.26-7.35 (m, 3H, ArH), 5.74-5.93 $\left(\mathrm{m}, 1 \mathrm{H},-\mathrm{CH}_{2}-\mathrm{CH}=\mathrm{CH}_{2}\right), 5.58(\mathrm{~s}, 1 \mathrm{H}, \mathrm{PhCH}), 5.42(\mathrm{dd}, 1 \mathrm{H}, \mathrm{J}=1.6,3.7 \mathrm{~Hz}, 2-\mathrm{H}), 5.22-$ $5.31\left(\mathrm{~m}, 1 \mathrm{H},-\mathrm{CH}_{2}-\mathrm{CH}=\mathrm{CH}_{2}\right), 5.13-5.20\left(\mathrm{~m}, 1 \mathrm{H},-\mathrm{CH}_{2}-\mathrm{CH}=\mathrm{CH}_{2}\right), 4.92(\mathrm{~d}, 1 \mathrm{H}, J=1.6$ $\mathrm{Hz}, 1-\mathrm{H}), 4.29-4.35$ (m, 1H, 3-H), 4.24 (dd, 1H, J = 4.3, 9.9 Hz, 6-H), 4.09-4.19 (m, $\left.1 \mathrm{H},-\mathrm{CH}_{2}-\mathrm{CH}=\mathrm{CH}_{2}\right), 3.93-4.01\left(\mathrm{~m}, 2 \mathrm{H}, 4-\mathrm{H},-\mathrm{CH}_{2}-\mathrm{CH}=\mathrm{CH}_{2}\right), 3.89(\mathrm{dt}, 1 \mathrm{H}, J=4.3,9.5$ $\mathrm{Hz}, 5-\mathrm{H}), 3.75-3.85\left(\mathrm{~m}, 1 \mathrm{H}, 6\right.$ '-H), $2.31(\mathrm{~s}, 1 \mathrm{H}, \mathrm{OH}) .{ }^{13} \mathrm{C} \mathrm{NMR}\left(101 \mathrm{MHz}, \mathrm{CDCl}_{3}\right) \delta=$ 166.01, 137.12, 133.41, 133.19, 129.88, 129.57, 129.23, 128.47, 128.32, 126.24, 118.03, 102.25, 97.75, 79.47, 72.65, 68.81, 68.55, 67.55, 63.54. HRMS (ESI) Calcd for $\mathrm{C}_{23} \mathrm{H}_{25} \mathrm{O}_{7}[\mathrm{M}+\mathrm{H}]^{+}:$413.1595, found:413.1595; $\mathrm{C}_{23} \mathrm{H}_{28} \mathrm{NO}_{6}\left[\mathrm{M}+\mathrm{NH}_{4}\right]^{+}:$430.1860, found: 430.1857 .
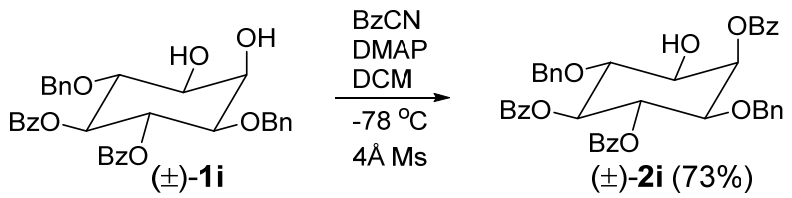

$( \pm)-\mathbf{i}(73 \%)$

\section{2,5,6-tri-O-benzoyl-1,4-di-O-benzyl -myo- inositol (2i)}

To a solution of compound $\mathbf{1 i}(30 \mathrm{mg}, 52.8 \mu \mathrm{mol})$ and $4 \AA$ molecular sieves in $12 \mathrm{~mL}$ of dry DCM was added benzoyl cyanide $(7.6 \mathrm{mg}, 58.1 \mu \mathrm{mol})$ at room temperature under nitrogen atmosphere. After cooling down the reaction mixture to $-78{ }^{\circ} \mathrm{C}$, 4dimethylaminopyridine (DMAP) $(3 \mathrm{mg}, 24.5 \mu \mathrm{mol})$ was added. The reaction was further stirred over $10 \mathrm{~h}$ at this temperature. Then the reaction was quenched by addition of $\mathrm{NH}_{4} \mathrm{Cl}$ (aq) and $100 \mu \mathrm{L} \mathrm{MeOH}$. Then the mixture was diluted with $100 \mathrm{~mL}$ of DCM and the precipitate was filtered off through a pad of Celite. The organic layer was washed with $\mathrm{NH}_{4} \mathrm{Cl}$ (aq) and $\mathrm{Na}_{2} \mathrm{~S}_{2} \mathrm{O}_{3}$ (aq), dried over $\mathrm{Na}_{2} \mathrm{SO}_{4}$, filtered, and concentrated. The residue was purified by column chromatography (hexane/ethyl acetate $=3: 1)$ on silica gel to afford compound $\mathbf{2 i}(26 \mathrm{mg}, 73 \%)$ as oil. ${ }^{1} \mathrm{H}$ NMR (400 $\left.\mathrm{MHz}, \mathrm{CDCl}_{3}\right) \delta=8.08-8.17(\mathrm{~m}, 2 \mathrm{H}, \mathrm{ArH}), 7.93-8.02(\mathrm{~m}, 2 \mathrm{H}, \mathrm{ArH}), 7.83-7.94(\mathrm{~m}, 2 \mathrm{H}$, 
$\operatorname{ArH})$, 7.58-7.67 (m, 1H, ArH), 7.42-7.58 (m, 4H, ArH), 7.29-7.41 (m, 4H, ArH), 7.04$7.22(\mathrm{~m}, 10 \mathrm{H}, \mathrm{ArH}), 6.05$ (t, 1H, J = 2.9 Hz, 2-H), 5.94 (t, 1H, J=9.9 Hz, 6-H), 5.59 (t, $1 \mathrm{H}, J=9.7 \mathrm{~Hz}, 5-\mathrm{H}), 4.57-4.76\left(\mathrm{~m}, 3 \mathrm{H}, \mathrm{PhCH}_{2}\right), 4.50$ (d, 1H, J = 1.27 Hz, $\mathrm{PhCH}_{2}$ ), $4.13(\mathrm{t}, 1 \mathrm{H}, J=9.6,4-\mathrm{H}), 3.94-4.01(\mathrm{~m}, 1 \mathrm{H}, 3-\mathrm{H}), 3.80$ (dd, 1H, $J=2.9,9.9 \mathrm{~Hz}, 1-\mathrm{H})$, $2.69(\mathrm{~d}, 1 \mathrm{H}, J=3.6 \mathrm{~Hz}, \mathrm{OH}) .{ }^{13} \mathrm{C} \mathrm{NMR}\left(100 \mathrm{MHz}, \mathrm{CDCl}_{3}\right) \delta=166.27,165.76,165.61$, $137.36,136.93$, 133.32, 133.18, 133.03, 129.97, 129.76, 129.70, 129.40, 129.31, $128.54,128.41,128.35,128.26,128.23,128.11,127.96,127.89,127.77,79.08,75.06$, 74.62, 72.84, 71.67, 71.35, 70.63, 69.57. HRMS (ESI) Calcd for $\mathrm{C}_{41} \mathrm{H}_{40} \mathrm{NO} 9[\mathrm{M}+$ $\left.\mathrm{NH}_{4}\right]^{+}: 690.2698$, found: 690.2692 .
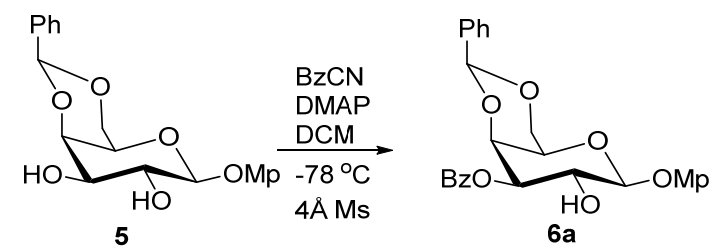

\section{4-Methoxyphenyl 3-O-benzoyl-4,6-O-benzylidene- $\beta$-D-galactopyranoside (6a)}

To a solution of compound $5(40 \mathrm{mg}, 107.0 \mu \mathrm{mol})$ and $4 \AA$ molecular sieves in $3 \mathrm{~mL}$ of dry DCM was added benzoyl cyanide $(14.5 \mathrm{mg}, 110.7 \mu \mathrm{mol})$ at room temperature under nitrogen atmosphere. After cooling down the reaction mixture to $-78{ }^{\circ} \mathrm{C}$, 4dimethylaminopyridine (DMAP) $(2 \mathrm{mg}, 14.2 \mu \mathrm{mol})$ was added. The reaction was further stirred for $4 \mathrm{~h}$ at this temperature. After the TLC analysis showed the reaction was complete, the reaction was quenched by addition of $\mathrm{NH}_{4} \mathrm{Cl}$ (aq) and $100 \mu \mathrm{L} \mathrm{MeOH}$. Then the mixture was diluted with $100 \mathrm{~mL}$ of DCM and the precipitate was filtered off through a pad of Celite. The organic layer was washed with $\mathrm{NH}_{4} \mathrm{Cl}$ (aq) and $\mathrm{Na}_{2} \mathrm{~S}_{2} \mathrm{O}_{3}$ (aq), dried over $\mathrm{Na}_{2} \mathrm{SO}_{4}$, filtered, and concentrated. The residue was purified by column chromatography (hexane/ethyl acetate $=2: 1$ ) on silica gel to afford compound $\mathbf{6 a}^{\mathbf{3}}$ (51.2 $\mathrm{mg}, 99 \%)$ as white solid.

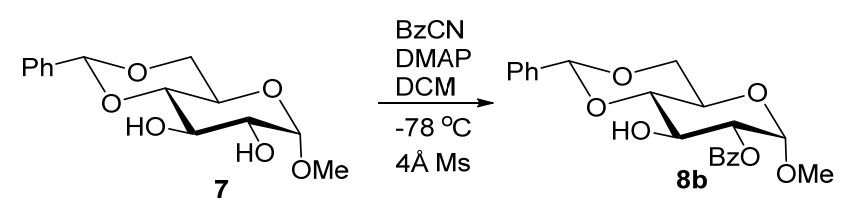

\section{Methyl 2-O-benzoyl-4,6-O-benzylidene- $\alpha$-D-gluctopyranoside (8b)}

To a solution of compound 7 (30 mg, $106.3 \mu \mathrm{mol})$ and $4 \AA$ molecular sieves in $3 \mathrm{~mL}$ of dry DCM was added benzoyl cyanide $(14.5 \mathrm{mg}, 110.7 \mu \mathrm{mol})$ at room temperature under nitrogen atmosphere. After cooling down the reaction mixture to $-78{ }^{\circ} \mathrm{C}$, 4dimethylaminopyridine (DMAP) $(1.5 \mathrm{mg}, 10.6 \mu \mathrm{mol})$ was added. The reaction was further stirred for $4 \mathrm{~h}$ at this temperature. After the TLC analysis showed the reaction was complete, the reaction was quenched by addition of $\mathrm{NH}_{4} \mathrm{Cl}(\mathrm{aq})$ and $100 \mu \mathrm{L} \mathrm{MeOH}$. 
Then the mixture was diluted with $100 \mathrm{~mL}$ of DCM and the precipitate was filtered off through a pad of Celite. The organic layer was washed with $\mathrm{NH}_{4} \mathrm{Cl}$ (aq) and $\mathrm{Na}_{2} \mathrm{~S}_{2} \mathrm{O}_{3}$ (aq), dried over $\mathrm{Na}_{2} \mathrm{SO}_{4}$, filtered, and concentrated. The residue was purified by column chromatography (hexane/ethyl acetate $=2: 1$ ) on silica gel to afford compound $\mathbf{8 b}^{\mathbf{4}}$ (35.6 mg, 86\%) as white solid.
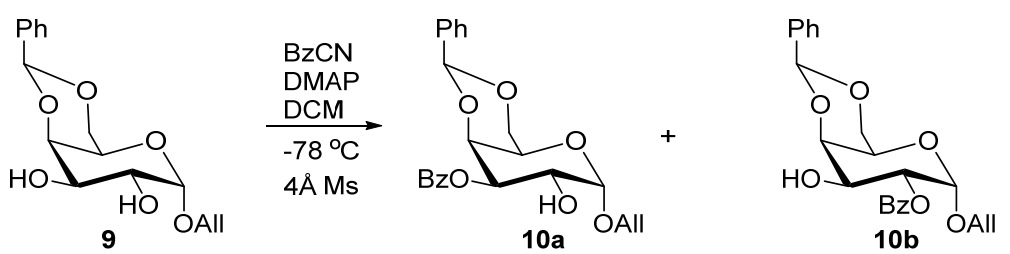

Allyl 3-O-benzoyl-4,6-O-benzylidene- $\beta$-D-galactopyranoside (10a) and Allyl 2-Obenzoyl-4,6-O-benzylidene- $\beta$-D-galactopyranoside (10b)

To a solution of compound 9 (30 mg, $97.4 \mu \mathrm{mol})$ and $4 \AA$ molecular sieves in $3 \mathrm{~mL}$ of dry DCM was added benzoyl cyanide $(14 \mathrm{mg}, 106.9 \mu \mathrm{mol})$ at room temperature under nitrogen atmosphere. After cooling down the reaction mixture to $-78{ }^{\circ} \mathrm{C}$, 4dimethylaminopyridine (DMAP) $(1.5 \mathrm{mg}, 10.6 \mu \mathrm{mol})$ was added. The reaction was further stirred for $4 \mathrm{~h}$ at this temperature. After the TLC analysis showed the reaction was complete, the reaction was quenched by addition of $\mathrm{NH}_{4} \mathrm{Cl}$ (aq) and $100 \mu \mathrm{L} \mathrm{MeOH}$. Then the mixture was diluted with $100 \mathrm{~mL}$ of DCM and the precipitate was filtered off through a pad of Celite. The organic layer was washed with $\mathrm{NH}_{4} \mathrm{Cl}$ (aq) and $\mathrm{Na}_{2} \mathrm{~S}_{2} \mathrm{O}_{3}$ (aq), dried over $\mathrm{Na}_{2} \mathrm{SO}_{4}$, filtered, and concentrated. The residue was purified by column chromatography (hexane/ethyl acetate $=2: 1$ ) on silica gel to afford compound 10b (10.1 $\mathrm{mg}, 25 \%)$ and $\mathbf{1 0 a}^{\mathbf{5}}(25.8 \mathrm{mg}, 65 \%)$ as white solid.

3. Procedures for DMAP catalyzed regioselectively benzoylation with $\mathrm{Bz}_{2} \mathrm{O}$ or $\mathrm{BzF}$ as reagent:



\section{4-Methoxyphenyl 3-O-benzoyl-2,6-di-O-benzyl- $\beta$-D-galactopyranoside (3a)}

To a solution of compound 1a $(30 \mathrm{mg}, 64.4 \mu \mathrm{mol})$ and $4 \AA$ molecular sieves in $3 \mathrm{~mL}$ of dry DCM was added benzoyl cyanide $(16 \mathrm{mg}, 70.8 \mu \mathrm{mol})$ at room temperature under nitrogen atmosphere. After cooling down the reaction mixture to $-78{ }^{\circ} \mathrm{C}$, 4dimethylaminopyridine (DMAP) $(1 \mathrm{mg}, 7.1 \mu \mathrm{mol})$ was added. The reaction was further stirred for $10 \mathrm{~h}$ at this temperature (or regularly raised the temperature to $-50{ }^{\circ} \mathrm{C}$ over 3 h). After the TLC analysis showed the reaction was complete, the reaction was quenched by addition of $\mathrm{NaHCO}_{3}$ (aq). Then the mixture was diluted with $100 \mathrm{~mL}$ of 
DCM and the precipitate was filtered off through a pad of Celite. The organic layer was washed with $\mathrm{NaHCO}_{3}$ (aq) over $\mathrm{Na}_{2} \mathrm{SO}_{4}$, filtered, and concentrated. The residue was purified by column chromatography (hexane/ethyl acetate $=3: 1$ ) on silica gel to afford compound 3a (33.1 mg, 90\%) as white solid. ${ }^{1} \mathrm{H}$ NMR (400 MHz, $\left.\mathrm{CDCl}_{3}\right) \delta=7.89$ 7.96 (m, 2H, ArH), 7.47-7.55 (m, 1H, ArH), 7.36 (t, 2H, J=7.7 Hz, ArH), 7.04-7.29 (m, 10H, ArH), 6.96-7.04 (m, 2H, ArH), 6.70-6.80 (m, 2H, ArH), 5.12 (dd, 1H, J=3.2, $10.0 \mathrm{~Hz}, 3-\mathrm{H}), 4.93$ (d, 1H, J=7.7 Hz, 1-H), 4.86 (d, 1H, J=11.5 Hz, $\left.\mathrm{PhCH}_{2}\right), 4.72$ (d, $\left.1 \mathrm{H}, J=11.5 \mathrm{~Hz}, \mathrm{PhCH}_{2}\right), 4.50$ (d, $\left.1 \mathrm{H}, J=11.6 \mathrm{~Hz}, \mathrm{PhCH}_{2}\right), 4.47$ (d, $1 \mathrm{H}, J=11.6 \mathrm{~Hz}$, $\left.\mathrm{PhCH}_{2}\right), 4.22$ (d, 1H, J=3.2 Hz, 4-H), 4.07 (dd, 1H, $\left.J=7.7,10.0 \mathrm{~Hz}, 2-\mathrm{H}\right), 3.68-3.77$ (m, 3H, 5-H, 6-H, 6'-H), 3.69 (s, 3H, OMe), 2.60 (d, 1H, J=4.5, OH). ${ }^{13} \mathrm{C}$ NMR (100 $\left.\mathrm{MHz}, \mathrm{CDCl}_{3}\right) \delta=165.75,155.45,151.34,137.88,137.61,133.24,129.85,129.65$, $128.50,128.42,128.40,128.30,128.23,128.16,128.13,127.80,127.69,127.63,118.64$, 114.56, 103.34, 75.98, 75.41, 74.77, 73.74, 73.21, 69.46, 68.12, 55.63. HRMS (ESI) Calcd for $\mathrm{C}_{34} \mathrm{H}_{38} \mathrm{NO}_{8}\left[\mathrm{M}+\mathrm{NH}_{4}\right]^{+}: 588.2592$, found: 588.2596 .

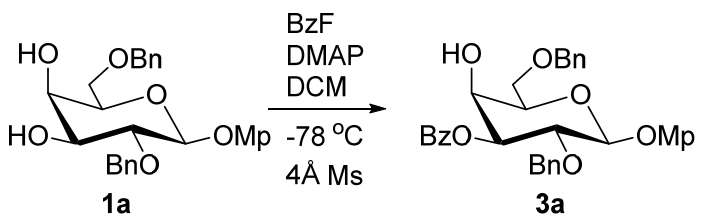

\section{4-Methoxyphenyl 3-O-benzoyl-2,6-di-O-benzyl- $\beta$-D-galactopyranoside (3a)}

To a solution of compound 1a (20 mg, $42.9 \mu \mathrm{mol})$ and $4 \AA$ molecular sieves in $3 \mathrm{~mL}$ of dry DCM was added benzoyl cyanide $(5 \mu \mathrm{L}, 46.4 \mu \mathrm{mol})$ at room temperature under nitrogen atmosphere. After cooling down the reaction mixture to $-78{ }^{\circ} \mathrm{C}$, 4dimethylaminopyridine (DMAP) $(0.7 \mathrm{mg}, 5.7 \mu \mathrm{mol})$ was added. The reaction was further stirred for $1 \mathrm{~h}$ at this temperature and then regularly raised the temperature to $10{ }^{\circ} \mathrm{C}$ over $10 \mathrm{~h}$. After the TLC analysis showed the reaction was complete, the reaction was quenched by addition of $\mathrm{NaHCO}_{3}$ (aq). Then the mixture was diluted with $100 \mathrm{~mL}$ of DCM and the precipitate was filtered off through a pad of Celite. The organic layer was washed with $\mathrm{NaHCO}_{3}$ (aq) dried over $\mathrm{Na}_{2} \mathrm{SO}_{4}$, filtered, and concentrated. The residue was purified by column chromatography (hexane/ethyl acetate $=3: 1$ ) on silica gel to afford compound $\mathbf{3 a}(20.7 \mathrm{mg}, 84 \%)$ and $\mathbf{2 a}(1.8 \mathrm{mg}, 7 \%)$ as white solid.

\section{Procedure for TBACN promoted cyanide-mediated selectively benzoylation.}

To a solution of compound 1a (30 mg, $64.4 \mu \mathrm{mol})$ and 4 Å molecular sieves in $3 \mathrm{~mL}$ of dry DCM was added TBACN (19 mg, $70.8 \mu \mathrm{mol})$ at room temperature under nitrogen atmosphere. After cooling down the reaction mixture to $-78{ }^{\circ} \mathrm{C}, \mathrm{Bz} 2 \mathrm{O}(15 \mathrm{mg}, 66.6$ $\mu \mathrm{mol})$, dissolved in $2 \mathrm{~mL}$ dry DCM, was added dropwise via syringe. The reaction was further stirred for $3 \mathrm{~h}$ at this temperature. After the TLC analysis showed the reaction 
was complete, the reaction was quenched by addition of $\mathrm{NH}_{4} \mathrm{Cl}$ (aq) and $100 \mu \mathrm{L} \mathrm{MeOH}$. Then the mixture was diluted with $100 \mathrm{~mL}$ of DCM and the precipitate was filtered off through a pad of Celite. The organic layer was washed with $\mathrm{NH}_{4} \mathrm{Cl}$ (aq) and $\mathrm{Na}_{2} \mathrm{~S}_{2} \mathrm{O}_{3}$ (aq), dried over $\mathrm{Na}_{2} \mathrm{SO}_{4}$, filtered, and concentrated. The residue was purified by column chromatography (hexane/ethyl acetate $=2: 1$ ) on silica gel to afford compound $2 \mathbf{a}$ and (16.2 $\mathrm{mg}, 44 \%)$ as white solid.

\section{Procedures for DMAP catalyzed cyanide-mediated regioselective acetylation:}

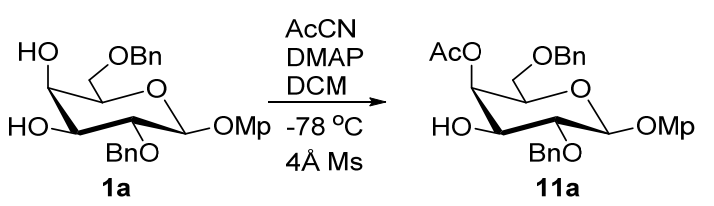

\section{4-Methoxyphenyl 4-O-acetyl-2,6-di-O-benzyl- $\beta$-D-galactopyranoside (11a)}

To a solution of compound 1a (30 mg, $64.4 \mu \mathrm{mol})$ and $4 \AA$ molecular sieves in $3 \mathrm{~mL}$ of dry DCM was added acetyl cyanide $(5 \mu \mathrm{L}, 70.8 \mu \mathrm{mol})$ at room temperature under nitrogen atmosphere. After cooling down the reaction mixture to $-78{ }^{\circ} \mathrm{C}$, 4dimethylaminopyridine (DMAP) $(1 \mathrm{mg}, 7.1 \mu \mathrm{mol})$ was added. The reaction was further stirred for $4 \mathrm{~h}$ at this temperature. After the TLC analysis showed the reaction was complete, the reaction was quenched by addition of $\mathrm{NH}_{4} \mathrm{Cl}(\mathrm{aq})$ and $100 \mu \mathrm{L} \mathrm{MeOH}$. Then the mixture was diluted with $100 \mathrm{~mL}$ of DCM and the precipitate was filtered off through a pad of Celite. The organic layer was washed with $\mathrm{NH}_{4} \mathrm{Cl}$ (aq) and $\mathrm{Na}_{2} \mathrm{~S}_{2} \mathrm{O}_{3}$ (aq), dried over $\mathrm{Na}_{2} \mathrm{SO}_{4}$, filtered, and concentrated. The residue was purified by column chromatography (hexane/ethyl acetate $=2: 1$ ) on silica gel to afford compound $\mathbf{1 1 a}^{\mathbf{6}}$ (26.5 $\mathrm{mg}, 81 \%)$ as white solid.

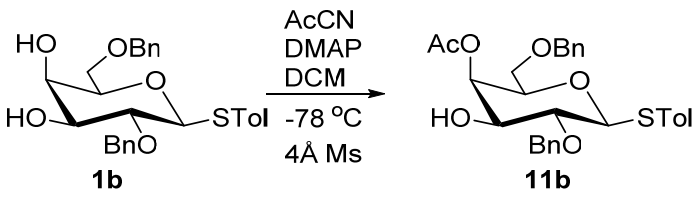

\section{4-Methylphenyl 4-O-acetyl-2,6-di-O-benzyl-1-thio- $\beta$-D-galactopyranoside (11b)}

To a solution of compound $\mathbf{1 b}(30 \mathrm{mg}, 64.4 \mu \mathrm{mol})$ and $4 \AA$ molecular sieves in $3 \mathrm{~mL}$ of dry DCM was added acetyl cyanide $(5 \mu \mathrm{L}, 70.8 \mu \mathrm{mol})$ at room temperature under nitrogen atmosphere. After cooling down the reaction mixture to $-78{ }^{\circ} \mathrm{C}$, 4 dimethylaminopyridine (DMAP) $(1 \mathrm{mg}, 7.1 \mu \mathrm{mol})$ was added. The reaction was further stirred for $4 \mathrm{~h}$ at this temperature. After the TLC analysis showed the reaction was complete, the reaction was quenched by addition of $\mathrm{NH}_{4} \mathrm{Cl}(\mathrm{aq})$ and $100 \mu \mathrm{L} \mathrm{MeOH}$. Then the mixture was diluted with $100 \mathrm{~mL}$ of DCM and the precipitate was filtered off through a pad of Celite. The organic layer was washed with $\mathrm{NH}_{4} \mathrm{Cl}$ (aq) and $\mathrm{Na}_{2} \mathrm{~S}_{2} \mathrm{O}_{3}$ (aq), dried over $\mathrm{Na}_{2} \mathrm{SO}_{4}$, filtered, and concentrated. The residue was purified by column chromatography (hexane/ethyl acetate $=2: 1$ ) on silica gel to afford compound $\mathbf{1 1}^{\mathbf{7}}$ 
(25.2 $\mathrm{mg}, 78 \%)$ as white solid.

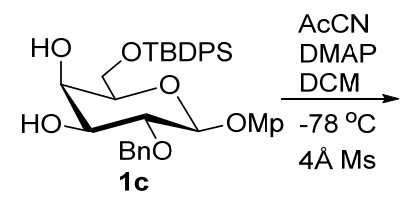

4-Methoxyphenyl

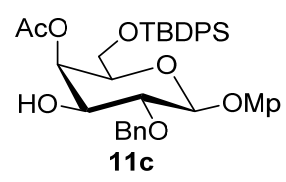

4-O-acetyl-2-O-benzyl-6-O-tert-butyldiphenylsilyl- $\beta$-Dgalactopyranoside (11c)

To a solution of compound 1c (36 mg, $58.6 \mu \mathrm{mol})$ and $4 \AA$ molecular sieves in $3 \mathrm{~mL}$ of dry DCM was added acetyl cyanide $(5 \mu \mathrm{L}, 70.8 \mu \mathrm{mol})$ at room temperature under nitrogen atmosphere. After cooling down the reaction mixture to $-78{ }^{\circ} \mathrm{C}$, 4dimethylaminopyridine (DMAP) $(1 \mathrm{mg}, 7.1 \mu \mathrm{mol})$ was added. The reaction was further stirred for $4 \mathrm{~h}$ at this temperature. After the TLC analysis showed the reaction was complete, the reaction was quenched by addition of $\mathrm{NH}_{4} \mathrm{Cl}(\mathrm{aq})$ and $100 \mu \mathrm{L} \mathrm{MeOH}$. Then the mixture was diluted with $100 \mathrm{~mL}$ of DCM and the precipitate was filtered off through a pad of Celite. The organic layer was washed with $\mathrm{NH}_{4} \mathrm{Cl}$ (aq) and $\mathrm{Na}_{2} \mathrm{~S}_{2} \mathrm{O}_{3}$ (aq), dried over $\mathrm{Na}_{2} \mathrm{SO}_{4}$, filtered, and concentrated. The residue was purified by column chromatography (hexane/ethyl acetate $=3: 1$ ) on silica gel to afford compound 11c (35.0 mg, 91\%) as semisolid. ${ }^{1} \mathrm{H}$ NMR (400 MHz, $\left.\mathrm{CDCl}_{3}\right) \delta=7.50-7.61$ (m, 4H, $\mathrm{ArH}$ ), 7.20-7.38 (m, 12H, ArH), 6.91-6.98 (m, 2H, ArH), 6.66-6.74 (m, 2H, ArH), 5.39 (d, $1 \mathrm{H}, J=3.3 \mathrm{~Hz}, 4-\mathrm{H}), 4.99$ (d, 1H, $\left.J=11.2 \mathrm{~Hz}, \mathrm{PhCH}_{2}\right), 4.80$ (d, 1H, J=7.8 Hz, 1-H), 4.70 (d, 1H, $J=11.2 \mathrm{~Hz}, \mathrm{PhCH}_{2}$ ), 3.78 (ddd, 1H, $\left.J=1.7,3.4,10.1 \mathrm{~Hz}, 3-\mathrm{H}\right), 3.60-3.73$ (m, 4H, 2-H, 5-H, 6-H, 6'-H), 3.68 (s, 3H, OMe), 2.35 (d, 1H, J=2.5 Hz, OH), 1.96 (s, $3 \mathrm{H}, \mathrm{OAc}), 0.98$ (s, 9H, tert-Butyl). ${ }^{13} \mathrm{C} \mathrm{NMR}\left(100 \mathrm{MHz}, \mathrm{CDCl}_{3}\right) \delta=170.83,155.32$, 151.32 , 138.07, 135.58, 135.55, 133.00, 132.87, 129.84, 129.75, 128.52, 128.13, 127.96, 127.76, 127.71, 118.26, 114.54, 102.76, 79.09, 75.01, 74.02, 72.23, 69.03, 61.87, 55.62, 26.75, 20.76, 19.08. HRMS (ESI) Calcd for $\mathrm{C}_{38} \mathrm{H}_{48} \mathrm{NO}_{9} \mathrm{Si}\left[\mathrm{M}+\mathrm{NH}_{4}\right]^{+}$: 674.3144, found: 674.3148 .

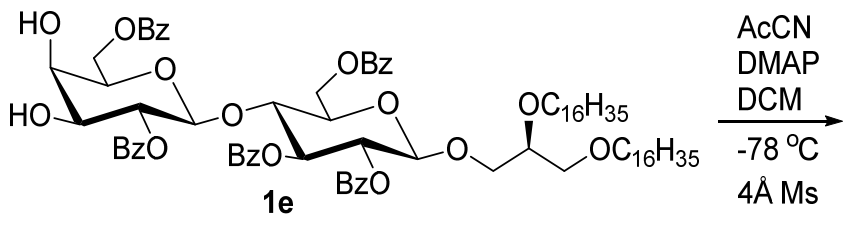

(2R)-2,3-Di-hexadecyloxypropyl

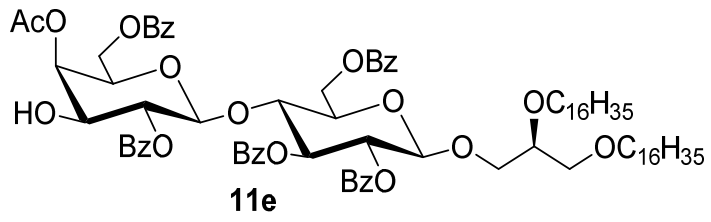

4-O-acetyl-2,6-di-O-benzoyl- $\beta$-D-

\section{galactopyranosyl-( $1 \rightarrow 4)$-2,3,6-tri-O-benzoyl- $\beta$-D-glucopyranoside (11e)}

To a solution of compound 1e (40 mg, $58.6 \mu \mathrm{mol})$ and $4 \AA$ molecular sieves in $3 \mathrm{~mL}$ of dry DCM was added acetyl cyanide $(2.5 \mu \mathrm{L}, 34.5 \mu \mathrm{mol})$ at room temperature under nitrogen atmosphere. After cooling down the reaction mixture to $-78{ }^{\circ} \mathrm{C}$, 4dimethylaminopyridine (DMAP) $(1 \mathrm{mg}, 7.1 \mu \mathrm{mol})$ was added. The reaction was further 
stirred for $4 \mathrm{~h}$ at this temperature. After the TLC analysis showed the reaction was complete, the reaction was quenched by addition of $\mathrm{NH}_{4} \mathrm{Cl}(\mathrm{aq})$ and $100 \mu \mathrm{L} \mathrm{MeOH}$. Then the mixture was diluted with $100 \mathrm{~mL}$ of DCM and the precipitate was filtered off through a pad of Celite. The organic layer was washed with $\mathrm{NH}_{4} \mathrm{Cl}$ (aq) and $\mathrm{Na}_{2} \mathrm{~S}_{2} \mathrm{O}_{3}$ (aq), dried over $\mathrm{Na}_{2} \mathrm{SO}_{4}$, filtered, and concentrated. The residue was purified by column chromatography (hexane/ethyl acetate $=2: 1$ ) on silica gel to afford compound 11e (32.0 mg, 78\%) as semisolid. ${ }^{1} \mathrm{H}$ NMR (400 MHz, $\left.\mathrm{CDCl}_{3}\right) \delta=7.84-8.02(\mathrm{~m}, 11 \mathrm{H}, \mathrm{ArH})$, 7.50-7.58 (m, 1, ArH), 7.38-7.50 (m, 6H, ArH), 7.23-7.36 (m, 8H, ArH), 5.64 (t, 1H, J $=9.6 \mathrm{~Hz}, 3 \mathrm{a}-\mathrm{H}), 5.35(\mathrm{dd}, 1 \mathrm{H}, J=8.0,10.0 \mathrm{~Hz}, 2 \mathrm{a}-\mathrm{H}), 5.13(\mathrm{~d}, 1 \mathrm{H}, J=3.6 \mathrm{~Hz}, 4 \mathrm{~b}-\mathrm{H})$, 5.08 (dd, 1H, $J=7.8,10.0 \mathrm{~Hz}, 2 \mathrm{~b}-\mathrm{H}), 4.67$ (d, 1H, $J=8.0 \mathrm{~Hz}, 1 \mathrm{a}-\mathrm{H}), 4.57$ (d, 1H, $J=$ $8.0 \mathrm{~Hz}, 1 \mathrm{~b}-\mathrm{H}), 4.54-4.57$ (m, 1H, 6a-H), 4.46 (dd, 1H, J=4.5, $\left.12.4 \mathrm{~Hz}, 6 \mathrm{a}{ }^{\prime}-\mathrm{H}\right), 4.11$ (t, $1 \mathrm{H}, J=9.5 \mathrm{~Hz}, 4 \mathrm{a}-\mathrm{H}), 3.72-3.78(\mathrm{~m}, 3 \mathrm{H}), 3.68(\mathrm{dd}, J=5.6,10.4 \mathrm{~Hz}), 3.43-3.55(\mathrm{~m}$, $3 \mathrm{H}), 3.33-3.41(\mathrm{~m}, 1 \mathrm{H}), 3.26-3.33(\mathrm{~m}, 2 \mathrm{H}), 3.23(\mathrm{dd}, 1 \mathrm{H}, J=4.2,10.3 \mathrm{~Hz}), 3.16$ (dd, $1 \mathrm{H}, J=5.4,10.3 \mathrm{~Hz}), 2.93-3.10(\mathrm{~m}, 2 \mathrm{H}), 2.40(\mathrm{~d}, 1 \mathrm{H}, J=6.2 \mathrm{~Hz}, \mathrm{OH}), 1.94(\mathrm{~s}, 3 \mathrm{H}$, $\mathrm{OAc}), 1.00-1.37(\mathrm{~m}, 60 \mathrm{H}), 0.81(\mathrm{t}, 6 \mathrm{H}, J=6.7 \mathrm{~Hz}, \mathrm{Me}) .{ }^{13} \mathrm{C} \mathrm{NMR}\left(100 \mathrm{MHz}, \mathrm{CDCl}_{3}\right)$ $\delta=170.51,166.46,165.94,165.62,165.32,165.07,133.50,133.40,133.32,133.11$, $129.94,129.87,129.79,129.73,129.60,129.56,129.55,129.53,129.38,128.92$, $128.64,128.57,128.54,128.52,128.29,128.19,101.36,100.41,75.66,73.53,72.97$, $72.71,71.75,71.61,71.49,71.20,70.47,70.11,69.33,68.97,62.64,61.22,31.91,29.95$, 29.69, 29.67, 29.65, 29.63, 29.59, 29.50, 29.44, 29.34, 25.98, 25.95, 22.67, 20.55, 14.09 . HRMS (ESI) Calcd for $\mathrm{C}_{84} \mathrm{H}_{118} \mathrm{NO}_{19}\left[\mathrm{M}+\mathrm{NH}_{4}\right]^{+}: 1444.8293$, found:1444.8301.

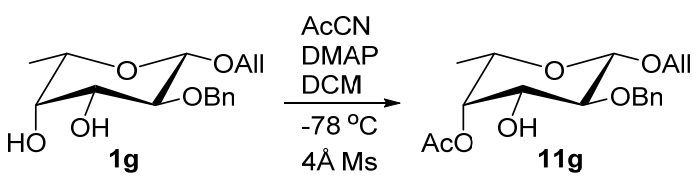

\section{Allyl 4-O-acetyl-2-O-benzyl- $\beta$-L-fucopyranoside (11g)}

To a solution of compound $\mathbf{1 g}(30 \mathrm{mg}, 102.0 \mu \mathrm{mol})$ and $4 \AA$ molecular sieves in $3 \mathrm{~mL}$ of dry DCM was added acetyl cyanide $(8 \mu \mathrm{L}, 112.2 \mu \mathrm{mol})$ at room temperature under nitrogen atmosphere. After cooling down the reaction mixture to $-78{ }^{\circ} \mathrm{C}$, 4dimethylaminopyridine (DMAP) $(1 \mathrm{mg}, 7.1 \mu \mathrm{mol})$ was added. The reaction was further stirred for $4 \mathrm{~h}$ at this temperature. After the TLC analysis showed the reaction was complete, the reaction was quenched by addition of $\mathrm{NH}_{4} \mathrm{Cl}(\mathrm{aq})$ and $100 \mu \mathrm{L} \mathrm{MeOH}$. Then the mixture was diluted with $100 \mathrm{~mL}$ of DCM and the precipitate was filtered off through a pad of Celite. The organic layer was washed with $\mathrm{NH}_{4} \mathrm{Cl}$ (aq) and $\mathrm{Na}_{2} \mathrm{~S}_{2} \mathrm{O}_{3}$ (aq), dried over $\mathrm{Na}_{2} \mathrm{SO}_{4}$, filtered, and concentrated. The residue was purified by column chromatography (hexane/ethyl acetate $=3: 1$ ) on silica gel to afford compound $\mathbf{1 1 g}$ (28.2 mg, 82\%) as semisolid. ${ }^{1} \mathrm{H}$ NMR (400 MHz, $\left.\mathrm{CDCl}_{3}\right) \delta=7.21-7.32$ (m, 5H, $\mathrm{ArH}$ ), 5.80-5.95 (m, $\left.1 \mathrm{H},-\mathrm{CH}_{2}-\mathrm{CH}=\mathrm{CH}_{2}\right), 5.24-5.33\left(\mathrm{~m}, 1 \mathrm{H},-\mathrm{CH}_{2}-\mathrm{CH}=\mathrm{CH}_{2}\right), 5.13-5.17$ (m, 
$\left.1 \mathrm{H},-\mathrm{CH}_{2}-\mathrm{CH}=\mathrm{CH}_{2}\right), 5.11(\mathrm{~d}, 1 \mathrm{H}, J=3.6 \mathrm{~Hz}, 4-\mathrm{H}), 4.93\left(\mathrm{~d}, 1 \mathrm{H}, J=11.2 \mathrm{~Hz}, \mathrm{PhCH}_{2}\right)$, $4.60\left(\mathrm{~d}, 1 \mathrm{H}, J=11.2 \mathrm{~Hz}, \mathrm{PhCH}_{2}\right), 4.35-4.40\left(\mathrm{~m}, 1 \mathrm{H},-\mathrm{CH}_{2}-\mathrm{CH}=\mathrm{CH}_{2}\right), 4.36(\mathrm{~d}, 1 \mathrm{H}, J=$ $7.6 \mathrm{~Hz}, 1-\mathrm{H}), 4.00-4.13$ (m, 1H, $-\mathrm{CH}_{2}-\mathrm{CH}=\mathrm{CH}_{2}$ ), 3.60-3.73 (m, 2H, H-3, H-5), 3.45 (dd, $1 \mathrm{H}, J=7.6,10.0 \mathrm{~Hz}, \mathrm{H}-2), 2.18(\mathrm{~d}, 1 \mathrm{H}, J=2.8 \mathrm{~Hz}, \mathrm{OH}), 2.07$ (s, 3H, OAc), 1.14 (d, $3 \mathrm{H}, J=6.5 \mathrm{~Hz}, \mathrm{Me}) .{ }^{13} \mathrm{C} \mathrm{NMR}\left(101 \mathrm{MHz}, \mathrm{CDCl}_{3}\right) \delta=171.12,138.32,133.90,128.51$, 128.10, 127.90, 117.44, 102.50, 79.06, 74.76, 72.07, 71.98, 70.30, 69.33, 20.82, 16.30 . HRMS (ESI) Calcd for $\mathrm{C}_{18} \mathrm{H}_{28} \mathrm{NO}_{6}\left[\mathrm{M}+\mathrm{NH}_{4}\right]^{+}: 354.1911$, found: 354.1914.

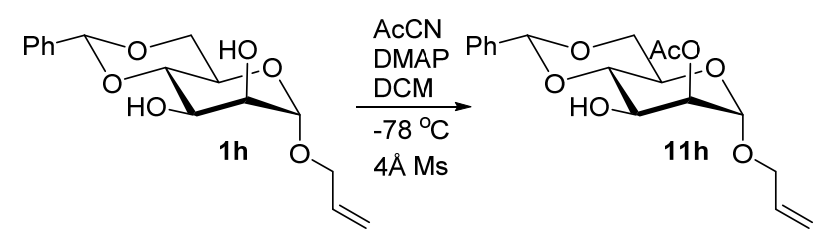

\section{Allyl 2-O-benzoyl-4,6-O-benzylidene- $\alpha$-D-mannopyranoside (11h)}

To a solution of compound $\mathbf{1 h}(36 \mathrm{mg}, 116.9 \mu \mathrm{mol})$ and $4 \AA$ molecular sieves in $3 \mathrm{~mL}$ of dry DCM was added acetyl cyanide $(10 \mu \mathrm{L}, 141.0 \mu \mathrm{mol})$ at room temperature under nitrogen atmosphere. After cooling down the reaction mixture to $-78{ }^{\circ} \mathrm{C}$, 4dimethylaminopyridine (DMAP) $(1 \mathrm{mg}, 7.1 \mu \mathrm{mol})$ was added. The reaction was further stirred for $4 \mathrm{~h}$ at this temperature. After the TLC analysis showed the reaction was complete, the reaction was quenched by addition of $\mathrm{NH}_{4} \mathrm{Cl}(\mathrm{aq})$ and $100 \mu \mathrm{L} \mathrm{MeOH}$. Then the mixture was diluted with $100 \mathrm{~mL}$ of DCM and the precipitate was filtered off through a pad of Celite. The organic layer was washed with $\mathrm{NH}_{4} \mathrm{Cl}$ (aq) and $\mathrm{Na}_{2} \mathrm{~S}_{2} \mathrm{O}_{3}$ (aq), dried over $\mathrm{Na}_{2} \mathrm{SO}_{4}$, filtered, and concentrated. The residue was purified by column chromatography (hexane/ethyl acetate $=3: 1$ ) on silica gel to afford compound $\mathbf{1 1} \mathbf{h}^{\mathbf{8}}$ (35.6 $\mathrm{mg}, 87 \%$ ) as semisolid.

\section{Procedures for DMAP catalyzed cyanide-mediated regioselective benzoylations of triols:}

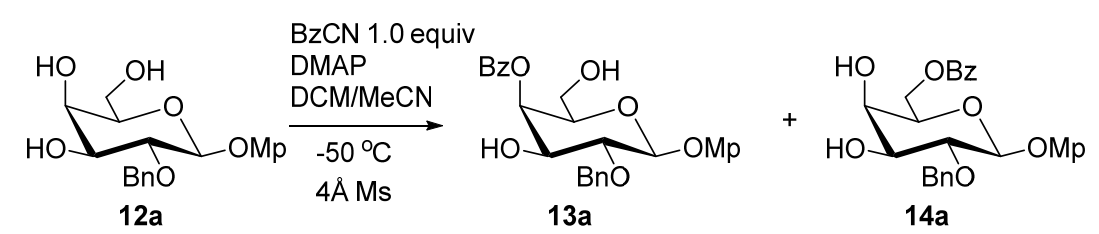

4-Methoxyphenyl 4-O-benzoyl-2-O-benzyl- $\beta$-D-galactopyranoside (13a) and 4methoxyphenyl 6-O-benzoyl-2-O-benzyl- $\beta$-D-galactopyranoside (14a)

To a solution of compound 12a (20 mg, $53.2 \mu \mathrm{mol})$ and $4 \AA$ molecular sieves in $5 \mathrm{~mL}$ of dry DCM and dry MeCN mixture (4/1) was added benzoyl cyanide (7.0 mg, 53.4 $\mu \mathrm{mol})$ at room temperature under nitrogen atmosphere. After cooling down the reaction mixture to $-60^{\circ} \mathrm{C}$, 4-dimethylaminopyridine (DMAP) $(1 \mathrm{mg}, 7.1 \mu \mathrm{mol})$ was added. The reaction was slowly raised to $-50{ }^{\circ} \mathrm{C}$ and further stirred for $4 \mathrm{~h}$ at this temperature. After the TLC analysis showed the reaction was complete, the reaction was quenched by 
addition of $\mathrm{NH}_{4} \mathrm{Cl}$ (aq) and $100 \mu \mathrm{L} \mathrm{MeOH}$. Then the mixture was diluted with $100 \mathrm{~mL}$ of DCM and the precipitate was filtered off through a pad of Celite. The organic layer was washed with $\mathrm{NH}_{4} \mathrm{Cl}(\mathrm{aq})$ and $\mathrm{Na}_{2} \mathrm{~S}_{2} \mathrm{O}_{3}$ (aq), dried over $\mathrm{Na}_{2} \mathrm{SO}_{4}$, filtered, and concentrated. The residue was purified by column chromatography (dichloromethane/ethyl acetate $=5: 1)$ on silica gel to afford compound 13a $(13.5 \mathrm{mg}$, $53 \%)$ and 14a (6.3 mg, 24\%) as white solid. Compound 13a ${ }^{1} \mathrm{H} \mathrm{NMR}\left(400 \mathrm{MHz}, \mathrm{CDCl}_{3}\right)$ $\delta=7.89-8.05(\mathrm{~m}, 2 \mathrm{H}, \mathrm{ArH}), 7.50-7.59(\mathrm{~m}, 1 \mathrm{H}, \operatorname{ArH}), 7.36-7.44(\mathrm{~m}, 2 \mathrm{H}, \mathrm{ArH}), 7.21-$ 7.36 (m, 5H, ArH), 6.86-7.03 (m, 2H, ArH),6.76-6.86 (m, 2H, ArH), 5.47 (d, 1H, J= $2.9 \mathrm{~Hz}, 4-\mathrm{H}), 5.04$ (d, 1H, J=11.2 Hz, $\left.\mathrm{PhCH}_{2}\right), 4.93$ (d, 1H, J = 6.9 Hz, 1-H), 4.77 (d, $\left.1 \mathrm{H}, J=11.2 \mathrm{~Hz}, \mathrm{PhCH}_{2}\right), 3.83-3.91(\mathrm{~m}, 2 \mathrm{H}, 2-\mathrm{H}, 3-\mathrm{H}), 3.78(\mathrm{t}, 1 \mathrm{H}, J=6.8 \mathrm{~Hz}, 5-\mathrm{H})$, 3.72 (s, 3H, OMe), 3.67-3.71 (m, 1H, 6-H), 3.51-3.53 (m, 1H, 6'-H), 2.61 (bs, 1H, OH), $2.36(\mathrm{bs}, 1 \mathrm{H}, \mathrm{OH}) .{ }^{13} \mathrm{C} \mathrm{NMR}\left(100 \mathrm{MHz}, \mathrm{CDCl}_{3}\right) \delta=167.42,155.54,151.13,137.88$, $133.67,130.13,129.06,128.65,128.52,128.39$, 128.16, 118.17, 114.74, 102.87, 78.78, 77.35, 74.93, 74.15, 71.77, 70.27, 60.60, 55.70. HRMS (ESI) Calcd for $\mathrm{C}_{27} \mathrm{H}_{32} \mathrm{NO} 8$ [M $\left.+\mathrm{NH}_{4}\right]^{+}:$498.2122, found: 498.2126. Compound 14a ${ }^{1} \mathrm{H}$ NMR $\left(400 \mathrm{MHz}, \mathrm{CDCl}_{3}\right) \delta=$ 7.86-8.10 (m, 2H, ArH), 7.45-7.57 (m, 1H, ArH), 7.35-7.43 (m, 2H, ArH), 7.22-7.35 (m, 4H, ArH), 6.92-6.99 (m, 2H, ArH), 6.60-6.71 (m, 2H, ArH), 5.02 (d, 1H, J=11.5 Hz, $\left.\mathrm{PhCH}_{2}\right), 4.79$ (d, 1H, J = 7.6 Hz, 1-H), 4.72 (d, 1H, J = 11.5 Hz, $\mathrm{PhCH}_{2}$ ), 4.61 (dd, $1 \mathrm{H}$, $J=5.3,11.5 \mathrm{~Hz}, 6-\mathrm{H}), 4.51$ (dd, 1H, $J=7.6,11.5 \mathrm{~Hz}, 6$ '-H), 3.97 (bs, 1H, 4-H), 3.87$3.82(\mathrm{~m}, 1 \mathrm{H}, 5-\mathrm{H}), 3.70-3.75(\mathrm{~m}, 1 \mathrm{H}, 2-\mathrm{H}), 3.67$ (s, 3H, OMe), 3.63-3.66 (m, 1H, 3-H), $2.52(\mathrm{~s}, 1 \mathrm{H}, \mathrm{OH}), 2.48(\mathrm{~s}, 1 \mathrm{H}, \mathrm{OH}) .{ }^{13} \mathrm{C} \mathrm{NMR}\left(101 \mathrm{MHz}, \mathrm{CDCl}_{3}\right) \delta=166.40,155.43$, 151.24, 138.08, 133.26, 129.77, 128.68, 128.44, 128.24, 128.11, 118.53, 114.50, 102.83, 78.59, 74.83, 72.94, 72.45, 68.18, 63.15, 55.62. HRMS (ESI) Calcd for $\mathrm{C}_{27} \mathrm{H}_{32} \mathrm{NO} 8$ [M $\left.+\mathrm{NH}_{4}\right]^{+}:$498.2122, found: 498.2126 .

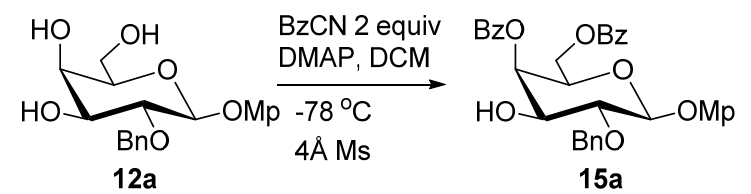

\section{4-Methoxyphenyl 4,6-di-O-benzoyl-2-O-benzyl- $\beta$-D-galactopyranoside (15a)}

To a solution of compound 12a (20 mg, $53.2 \mu \mathrm{mol})$ and $4 \AA$ molecular sieves in $5 \mathrm{~mL}$ of dry DCM was added benzoyl cyanide $(14.8 \mathrm{mg}, 113.0 \mu \mathrm{mol})$ at room temperature under nitrogen atmosphere. After cooling down the reaction mixture to $-78{ }^{\circ} \mathrm{C}$, 4dimethylaminopyridine (DMAP) $(1 \mathrm{mg}, 7.1 \mu \mathrm{mol})$ was added. The reaction was further stirred for $7 \mathrm{~h}$ at this temperature. After the TLC analysis showed the reaction was complete, the reaction was quenched by addition of $\mathrm{NH}_{4} \mathrm{Cl}(\mathrm{aq})$ and $100 \mu \mathrm{L} \mathrm{MeOH}$. Then the mixture was diluted with $100 \mathrm{~mL}$ of DCM and the precipitate was filtered off through a pad of Celite. The organic layer was washed with $\mathrm{NH}_{4} \mathrm{Cl}$ (aq) and $\mathrm{Na}_{2} \mathrm{~S}_{2} \mathrm{O}_{3}$ (aq), dried over $\mathrm{Na}_{2} \mathrm{SO}_{4}$, filtered, and concentrated. The residue was purified by column 
chromatography (hexane/ethyl acetate $=2: 1$ ) on silica gel to afford compound 15a (26.7 mg, 86\%) as white solid. ${ }^{1} \mathrm{H}$ NMR (400 MHz, $\left.\mathrm{CDCl}_{3}\right) \delta=8.01-8.06$ (m, 2H, ArH), 7.90-7.99 (m, 2H, ArH), 7.45-7.54 (m, 2H, ArH), 7.34-7.43 (m, 4H, ArH), 7.19-7.34 (m, 5H, ArH), 6.92-7.04 (m, 2H, ArH), 6.54-6.73 (m, 2H, ArH), 5.65 (d, 1H, J = 3.2 $\mathrm{Hz}, 4-\mathrm{H}), 5.04$ (d, 1H, J=11.2 Hz, $\left.\mathrm{PhCH}_{2}\right), 4.89$ (d, 1H, J = 7.5 Hz, 1-H), 4.75 (d, 1H, $J=11.2 \mathrm{~Hz}, \mathrm{PhCH}_{2}$ ), 4.47 (dd, 1H, $\left.J=7.8,11.5 \mathrm{~Hz}, 6-\mathrm{H}\right), 4.39$ (dd, 1H, $J=5.2,11.4$ Hz, 6'-H), 4.07-4.14 (m, 1H, 5-H), 3.92 (dd, 1H, J=3.4, 9.6 Hz, 3-H), 3.85 (dd, 1H, J $=7.5,9.7 \mathrm{~Hz}, 2-\mathrm{H}), 3.67(\mathrm{~s}, 3 \mathrm{H}, \mathrm{OMe}) .{ }^{13} \mathrm{C} \mathrm{NMR}\left(100 \mathrm{MHz}, \mathrm{CDCl}_{3}\right) \delta=166.17,166.01$, $155.46,151.23,137.88,133.45,133.24,130.08,129.78,129.60,129.28,128.58$, $128.47,128.42,128.25,128.07,118.34,114.53,102.88,78.85,75.05,72.09,71.66$, 69.63, 62.65, 55.60. HRMS (ESI) Calcd for $\mathrm{C}_{34} \mathrm{H}_{36} \mathrm{NO} 9\left[\mathrm{M}+\mathrm{NH}_{4}\right]^{+}: 602.2385$, found: 602.2388 .

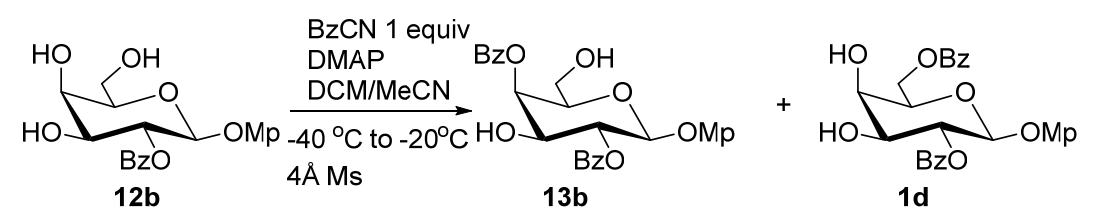

\section{4-Methoxyphenyl 2,4-di-O-benzoyl- $\beta$-D-galactopyranoside (13b) and 1d}

To a solution of compound 12b $(20 \mathrm{mg}, 51.3 \mu \mathrm{mol})$ and $4 \AA$ molecular sieves in $6 \mathrm{~mL}$ of dry DCM and dry MeCN mixture ( $/ \mathrm{v}=1 / 2)$ was added benzoyl cyanide $(7.0 \mathrm{mg}$, $53.4 \mu \mathrm{mol})$ at room temperature under nitrogen atmosphere. After cooling down the reaction mixture to $-40{ }^{\circ} \mathrm{C}$, 4-dimethylaminopyridine (DMAP) $(1 \mathrm{mg}, 7.1 \mu \mathrm{mol})$ was added. The reaction was regularly raised to $-20{ }^{\circ} \mathrm{C}$ over $4 \mathrm{~h}$. After the TLC analysis showed the reaction was complete, the reaction was quenched by addition of $\mathrm{NH}_{4} \mathrm{Cl}$ (aq) and $100 \mu \mathrm{L} \mathrm{MeOH}$. Then the mixture was diluted with $100 \mathrm{~mL}$ of DCM. Then the precipitate was filtered off through a pad of Celite. The organic layer was washed with $\mathrm{NH}_{4} \mathrm{Cl}$ (aq) and $\mathrm{Na}_{2} \mathrm{~S}_{2} \mathrm{O}_{3}$ (aq), dried over $\mathrm{Na}_{2} \mathrm{SO}_{4}$, filtered, and concentrated. The residue was purified by column chromatography (dichloromethane/ethyl acetate $=5: 1$ ) on silica gel to afford compound $\mathbf{1 3 b}(15.5 \mathrm{mg}, 61 \%)$ and $\mathbf{1 d}(1.8 \mathrm{mg}, 7 \%)$ as white solid. Compound 13b: ${ }^{1} \mathrm{H}$ NMR (400 MHz, $\left.\mathrm{CDCl}_{3}\right) \delta=8.04-8.12$ (m, $\left.2 \mathrm{H}, \mathrm{ArH}\right), 7.90$ 8.02 (m, 2H, ArH), 7.49-7.60 (m, 2H, ArH), 7.35-7.41 (m, 4H, ArH), 6.85-6.94 (m, 2H, $\operatorname{ArH}), 6.69-6.76(\mathrm{~m}, 2 \mathrm{H}, \mathrm{ArH}), 5.542(\mathrm{dd}, 1 \mathrm{H}, J=8.0,10.0 \mathrm{~Hz}, 2-\mathrm{H}), 5.540$ (d, 1H, $J=$ $4.0 \mathrm{~Hz}, 4-\mathrm{H}), 5.09$ (d, 1H, $J=7.9 \mathrm{~Hz}, 1-\mathrm{H}), 4.04-4.15(\mathrm{~m}, 1 \mathrm{H}, 3-\mathrm{H}), 3.87$ (t, $1 \mathrm{H}, J=$ $6.9 \mathrm{~Hz}, 5-\mathrm{H}), 3.69-3.75$ (m, 1H, 6-H), 3.68 (s, 3H, OMe), 4.04-4.15 (m, 6'-H), 2.78 (d, $1 \mathrm{H}, J=7.3 \mathrm{~Hz}, \mathrm{OH}), 2.71$ (bs, $1 \mathrm{H}, \mathrm{OH}) .{ }^{13} \mathrm{C} \mathrm{NMR}\left(100 \mathrm{MHz}, \mathrm{CDCl}_{3}\right) \delta=167.41$, $167.09,155.70,151.07,133.95,133.60,130.18,129.92,129.26,128.69$, 128.63, $128.53,118.65,114.62,100.75,74.21,73.70,71.82,70.99,60.50,55.62$. HRMS (ESI) Calcd for $\mathrm{C}_{27} \mathrm{H}_{30} \mathrm{NO}_{9}\left[\mathrm{M}+\mathrm{NH}_{4}\right]^{+}:$512.1915, found: 512.1920 . 


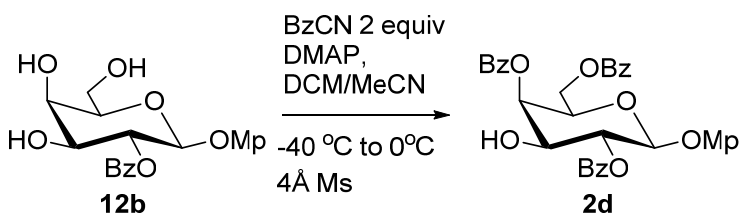

To a solution of compound $\mathbf{1 2 b}(20 \mathrm{mg}, 51.3 \mu \mathrm{mol})$ and $4 \AA$ molecular sieves in $4 \mathrm{~mL}$ of dry DCM and dry MeCN mixture (v/v = 1/1) was added benzoyl cyanide (14.5 mg, $110.7 \mu \mathrm{mol})$ at room temperature under nitrogen atmosphere. After cooling down the reaction mixture to $-40{ }^{\circ} \mathrm{C}$, 4-dimethylaminopyridine (DMAP) $(1 \mathrm{mg}, 7.1 \mu \mathrm{mol})$ was added. The reaction was regularly raised to $0{ }^{\circ} \mathrm{C}$ over $10 \mathrm{~h}$. After the TLC analysis showed the reaction was complete, the reaction was quenched by addition of $\mathrm{NH}_{4} \mathrm{Cl}$ (aq) and $100 \mu \mathrm{L} \mathrm{MeOH}$. Then the mixture was diluted with $100 \mathrm{~mL}$ of DCM. Then the precipitate was filtered off through a pad of Celite. The organic layer was washed with $\mathrm{NH}_{4} \mathrm{Cl}$ (aq) and $\mathrm{Na}_{2} \mathrm{~S}_{2} \mathrm{O}_{3}$ (aq), dried over $\mathrm{Na}_{2} \mathrm{SO}_{4}$, filtered, and concentrated. The residue was purified by column chromatography (hexane/ethyl acetate $=2: 1$ ) on silica gel to afford compound $\mathbf{2 d}(21.5 \mathrm{mg}, 70 \%)$ as white solid.

Table RW-1: Bond distances in $1 \mathbf{h} \cdots$ cyanide interactions (in $\AA$ ).

\begin{tabular}{|c|c|c|c|c|c|c|c|}
\hline & $\mathrm{H} 3_{\mathrm{eq}}-\mathrm{C} / \mathrm{N}$ & $\mathrm{H} 2 \mathrm{ax}-\mathrm{C} / \mathrm{N}$ & $\mathrm{O}_{\mathrm{eq}}-\mathrm{H} 3_{\mathrm{eq}}$ & $\mathrm{O} 2 \mathrm{ax}-\mathrm{H} 2_{\mathrm{ax}}$ & $\mathrm{O} 3_{\mathrm{eq}}-\mathrm{H} 2_{\mathrm{ax}}$ & $\mathrm{O} 2_{\mathrm{ax}}-\mathrm{H} 3_{\text {eq }}$ & $\mathrm{CN}$ \\
\hline $\mathrm{CN}^{-}$ & & & & & & & 1.17 \\
\hline $1 \mathrm{~h}$ & & & 0.96 & 0.97 & 2.22 & 3.57 & \\
\hline $2 \mathrm{ax}, 3_{\mathrm{eq}}-\mathrm{C}$ & 2.04 & 1.96 & 0.98 & 0.99 & 2.64 & 2.57 & 1.17 \\
\hline $2 \mathrm{ax}, 3_{\mathrm{eq}}-\mathrm{N}$ & 1.92 & 1.84 & 0.98 & 0.98 & 2.66 & 2.59 & 1.17 \\
\hline $2 \mathrm{ax}-\mathrm{N}$ & 4.09 & 1.73 & 0.97 & 1.00 & 3.35 & 2.12 & 1.17 \\
\hline $2 a x-C$ & 4.15 & 1.82 & 0.97 & 1.00 & 3.34 & 2.12 & 1.17 \\
\hline $3_{\text {eq }}-\mathrm{N}$ & 1.74 & 4.28 & 1.00 & 0.97 & 2.09 & 3.37 & 1.17 \\
\hline $3_{\text {eq }}-\mathrm{C}$ & 1.83 & 4.39 & 1.00 & 0.97 & 2.08 & 3.38 & 1.17 \\
\hline
\end{tabular}

Table RW-2: Bond distances in $\mathbf{1} \mathbf{h} \cdots$ fluoride interactions (in $\AA$ ).

$\begin{array}{llllll}\mathrm{H} 33_{e q}-\mathrm{F} & \mathrm{H} 2 \mathrm{ax}-\mathrm{F} & \mathrm{O}_{\text {eq }}-\mathrm{H} 3_{\mathrm{eq}} & \mathrm{O} 2 \mathrm{ax}-\mathrm{H} 3_{\mathrm{ax}} & 3 \mathrm{O}_{\text {eq }}-2 \mathrm{H}_{\mathrm{ax}} & 2 \mathrm{O}_{\mathrm{ax}}-3 \mathrm{H}_{\mathrm{eq}}\end{array}$

$1 \mathrm{~h}$

$2 \mathrm{ax}, 3 \mathrm{eq}-\mathrm{F}$
0.96

0.97

1.00

1.00
3.57

2.61 


\begin{tabular}{lllllll}
$2 \mathrm{ax}-\mathrm{F}$ & 3.88 & 1.38 & 0.97 & 1.05 & 3.42 & 2.06 \\
$3_{\mathrm{eq}}-\mathrm{F}$ & 1.37 & 4.39 & 1.05 & 0.97 & 2.04 & 3.67 \\
\hline
\end{tabular}

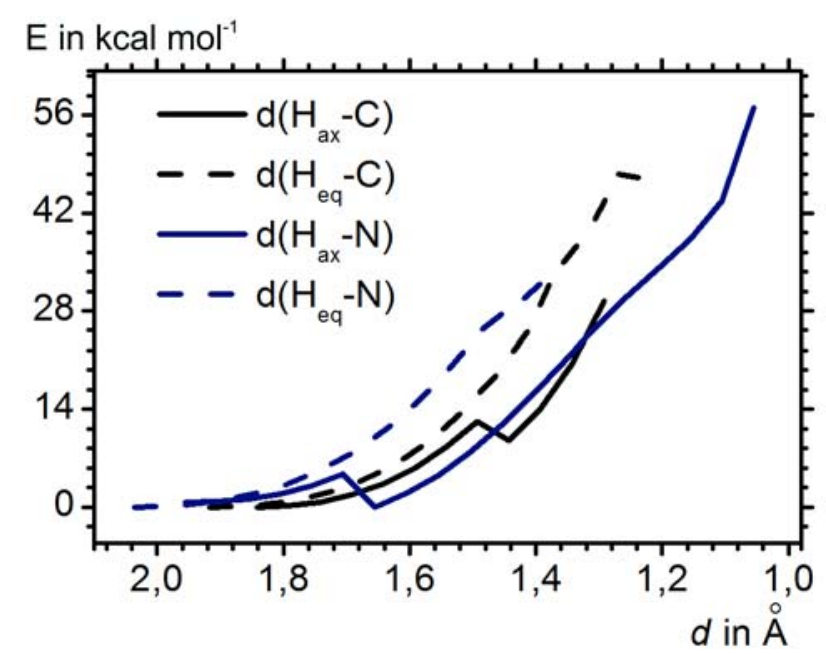

Figure RW-1: IRC-scans for the incremental decrease of the respective $\mathrm{H}-\mathrm{X} / \mathrm{Y}$ coordinate

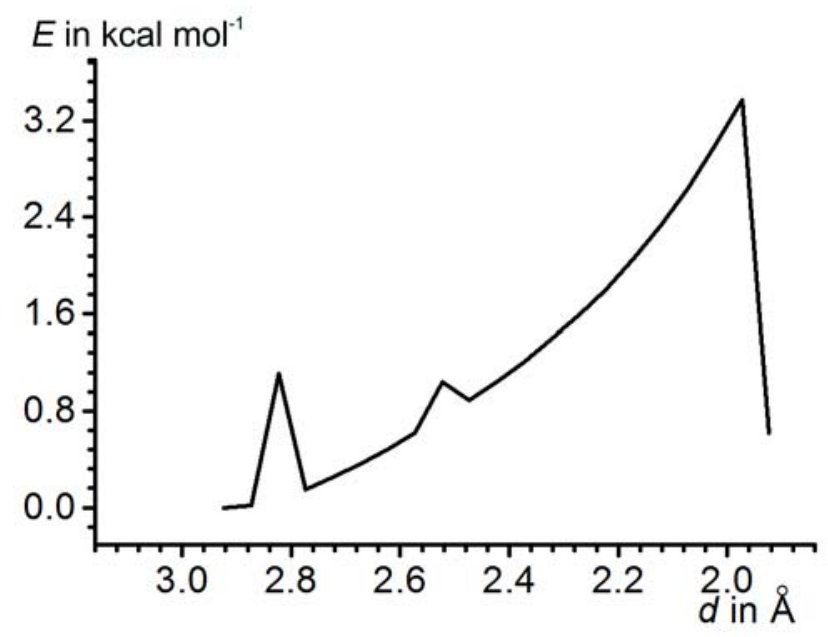

Figure RW-2: IRC-scans for the incremental decrease of the respective $\mathrm{H}-\mathrm{C}$ coordinate for the $\mathbf{2}$ ax, $\mathbf{3}_{\text {eq }}-\mathbf{N}$ to $\mathbf{2}$ ax, $\mathbf{3}_{\text {eq }}-\mathbf{C}$ conversion over a $\mathbf{2}$ ax $-\mathbf{C} / \mathbf{3}_{\text {eq }}-\mathbf{N}$ transition state. 
XYZ coordinates for the B3LYP/6-311++G(d,p)/PCM $\left(\mathrm{CH}_{2} \mathrm{Cl}_{2}\right)$ optimized geometry of 1h.

\begin{tabular}{|c|c|c|c|}
\hline $\mathrm{C}$ & -2.40794 & 0.73720 & 1.91475 \\
\hline $\mathrm{C}$ & -2.64344 & 0.85350 & 0.40872 \\
\hline $\mathrm{C}$ & -1.44097 & 0.26268 & -0.31694 \\
\hline $\mathrm{C}$ & -0.08454 & 0.79691 & 1.56153 \\
\hline $\mathrm{H}$ & -2.34120 & -0.32495 & 2.18558 \\
\hline $\mathrm{H}$ & -1.37742 & -0.81737 & -0.13092 \\
\hline $\mathrm{H}$ & -1.48635 & 0.43663 & -1.39157 \\
\hline $\mathrm{H}$ & -0.04928 & -0.27192 & 1.81961 \\
\hline $\mathrm{H}$ & -2.74130 & 1.90993 & 0.13670 \\
\hline $\mathrm{C}$ & -3.56487 & 1.37482 & 2.66272 \\
\hline $\mathrm{C}$ & -4.87733 & 0.70801 & 2.21852 \\
\hline $\mathrm{C}$ & -4.99951 & 0.64817 & 0.68585 \\
\hline $\mathrm{H}$ & -5.78008 & -0.06887 & 0.41750 \\
\hline $\mathrm{H}$ & -3.60676 & 2.44293 & 2.42123 \\
\hline $\mathrm{H}$ & -5.72120 & 1.29310 & 2.59892 \\
\hline $\mathrm{O}$ & -3.82814 & 0.13992 & 0.05406 \\
\hline $\mathrm{O}$ & -1.18079 & 1.38820 & 2.25883 \\
\hline $\mathrm{O}$ & -0.25788 & 0.92180 & 0.15831 \\
\hline $\mathrm{C}$ & 1.18803 & 1.49090 & 1.96664 \\
\hline $\mathrm{C}$ & 2.20565 & 0.77079 & 2.59344 \\
\hline $\mathrm{C}$ & 1.36041 & 2.85688 & 1.71983 \\
\hline $\mathrm{C}$ & 3.38834 & 1.40692 & 2.97336 \\
\hline $\mathrm{H}$ & 2.07640 & -0.28917 & 2.78536 \\
\hline $\mathrm{C}$ & 2.54011 & 3.49182 & 2.09884 \\
\hline $\mathrm{H}$ & 0.57253 & 3.41816 & 1.23212 \\
\hline $\mathrm{C}$ & 3.55645 & 2.76798 & 2.72649 \\
\hline $\mathrm{H}$ & 4.17403 & 0.83997 & 3.45956 \\
\hline $\mathrm{H}$ & 2.66876 & 4.55081 & 1.90530 \\
\hline $\mathrm{H}$ & 4.47438 & 3.26440 & 3.02061 \\
\hline $\mathrm{O}$ & -3.47096 & 1.19216 & 4.07617 \\
\hline $\mathrm{H}$ & -2.59304 & 1.47398 & 4.36052 \\
\hline $\mathrm{O}$ & -4.95373 & -0.63183 & 2.69633 \\
\hline $\mathrm{H}$ & -4.67637 & -0.61486 & 3.62201 \\
\hline $\mathrm{O}$ & -5.31048 & 1.94764 & 0.24978 \\
\hline $\mathrm{C}$ & -5.77298 & 2.04464 & -1.11664 \\
\hline $\mathrm{H}$ & -5.41830 & 3.00674 & -1.48989 \\
\hline $\mathrm{H}$ & -5.29938 & 1.25556 & -1.70956 \\
\hline $\mathrm{C}$ & -7.26904 & 1.96304 & -1.19969 \\
\hline $\mathrm{H}$ & -7.72728 & 1.06144 & -0.79879 \\
\hline $\mathrm{C}$ & -8.03392 & 2.90948 & -1.73974 \\
\hline $\mathrm{H}$ & -7.60606 & 3.82055 & -2.14805 \\
\hline $\mathrm{H}$ & -9.11137 & 2.80437 & -1.80044 \\
\hline
\end{tabular}


$\mathrm{XYZ}$ coordinates for the B3LYP/6-311++G(d,p)/PCM $\left(\mathrm{CH}_{2} \mathrm{Cl}_{2}\right)$ optimized geometry of $\mathbf{2}_{\text {ax }}, 3_{\text {eq }}-\mathbf{N}$

\begin{tabular}{|c|c|c|c|}
\hline $\mathrm{C}$ & -0.01362 & 0.44380 & -0.24507 \\
\hline $\mathrm{C}$ & 0.54523 & -0.91898 & -0.67598 \\
\hline $\mathrm{C}$ & -0.41741 & -1.55749 & -1.67035 \\
\hline $\mathrm{C}$ & -2.17882 & -0.34836 & -0.65066 \\
\hline $\mathrm{H}$ & -0.10569 & 1.09813 & -1.12168 \\
\hline $\mathrm{H}$ & -0.45239 & -0.96852 & -2.59632 \\
\hline $\mathrm{H}$ & -0.13023 & -2.58116 & -1.91073 \\
\hline $\mathrm{H}$ & -2.19120 & 0.31510 & -1.53247 \\
\hline $\mathrm{H}$ & 0.61142 & -1.56039 & 0.21019 \\
\hline $\mathrm{C}$ & 0.93156 & 1.07852 & 0.77014 \\
\hline $\mathrm{C}$ & 2.32960 & 1.18060 & 0.11474 \\
\hline $\mathrm{C}$ & 2.79314 & -0.18697 & -0.41414 \\
\hline $\mathrm{H}$ & 3.67397 & -0.04928 & -1.04655 \\
\hline $\mathrm{H}$ & 1.01321 & 0.40392 & 1.62771 \\
\hline $\mathrm{H}$ & 3.04694 & 1.50765 & 0.87655 \\
\hline $\mathrm{O}$ & 1.83161 & -0.78515 & -1.27818 \\
\hline $\mathrm{O}$ & -1.31479 & 0.22208 & 0.31325 \\
\hline $\mathrm{O}$ & -1.71736 & -1.62394 & -1.07057 \\
\hline $\mathrm{C}$ & -3.57007 & -0.48462 & -0.07243 \\
\hline $\mathrm{C}$ & -4.44501 & -1.45920 & -0.56181 \\
\hline $\mathrm{C}$ & -4.01403 & 0.40072 & 0.91401 \\
\hline $\mathrm{C}$ & -5.74469 & -1.55127 & -0.06527 \\
\hline $\mathrm{H}$ & -4.10472 & -2.14805 & -1.32449 \\
\hline $\mathrm{C}$ & -5.31437 & 0.30674 & 1.40909 \\
\hline $\mathrm{H}$ & -3.33928 & 1.15614 & 1.29557 \\
\hline $\mathrm{C}$ & -6.18358 & -0.66874 & 0.92157 \\
\hline $\mathrm{H}$ & -6.41332 & -2.31375 & -0.44939 \\
\hline $\mathrm{H}$ & -5.64649 & 0.99631 & 2.17719 \\
\hline $\mathrm{H}$ & -7.19437 & -0.74089 & 1.30739 \\
\hline $\mathrm{O}$ & 0.47550 & 2.31356 & 1.29561 \\
\hline $\mathrm{H}$ & 0.65762 & 3.05197 & 0.68003 \\
\hline $\mathrm{O}$ & 2.35090 & 2.05309 & -1.00619 \\
\hline $\mathrm{H}$ & 2.06505 & 2.95523 & -0.74445 \\
\hline $\mathrm{O}$ & 3.07782 & -1.00031 & 0.69965 \\
\hline $\mathrm{C}$ & 3.80648 & -2.21080 & 0.40488 \\
\hline $\mathrm{H}$ & 3.46821 & -2.95476 & 1.12853 \\
\hline $\mathrm{H}$ & 3.52859 & -2.56026 & -0.59500 \\
\hline $\mathrm{C}$ & 5.28959 & -2.00601 & 0.51482 \\
\hline $\mathrm{H}$ & 5.72224 & -1.24381 & -0.12973 \\
\hline $\mathrm{C}$ & 6.07480 & -2.70293 & 1.33370 \\
\hline
\end{tabular}




$\begin{array}{lrrr}\mathrm{H} & 5.67126 & -3.46839 & 1.99028 \\ \mathrm{H} & 7.14591 & -2.53866 & 1.37268 \\ \mathrm{~N} & 1.28693 & 4.56815 & -0.31116 \\ \mathrm{C} & 1.16710 & 5.72360 & -0.47149\end{array}$

XYZ coordinates for the B3LYP/6-311++G(d,p)/PCM $\left(\mathrm{CH}_{2} \mathrm{Cl}_{2}\right)$ optimized geometry of $\mathbf{3}_{\text {eq }}-\mathbf{N}$

\begin{tabular}{|c|c|c|c|}
\hline $\mathrm{C}$ & 0.02218 & 0.11472 & 0.81386 \\
\hline $\mathrm{C}$ & -0.58017 & -1.20657 & 0.32785 \\
\hline $\mathrm{C}$ & 0.37927 & -2.34316 & 0.66279 \\
\hline $\mathrm{C}$ & 2.16600 & -0.79289 & 0.56891 \\
\hline $\mathrm{H}$ & 0.14087 & 0.07450 & 1.90553 \\
\hline $\mathrm{H}$ & 0.45432 & -2.46641 & 1.75158 \\
\hline $\mathrm{H}$ & 0.05864 & -3.28613 & 0.22010 \\
\hline $\mathrm{H}$ & 2.21419 & -0.83786 & 1.67052 \\
\hline $\mathrm{H}$ & -0.71137 & -1.16142 & -0.75865 \\
\hline $\mathrm{C}$ & -0.88838 & 1.27969 & 0.45932 \\
\hline $\mathrm{C}$ & -2.32437 & 0.97625 & 0.96214 \\
\hline $\mathrm{C}$ & -2.80637 & -0.44765 & 0.65250 \\
\hline $\mathrm{H}$ & -3.65627 & -0.69115 & 1.29647 \\
\hline $\mathrm{H}$ & -0.90593 & 1.40306 & -0.62883 \\
\hline $\mathrm{H}$ & -3.01786 & 1.67292 & 0.47851 \\
\hline $\mathrm{O}$ & -1.83590 & -1.44122 & 0.96463 \\
\hline $\mathrm{O}$ & 1.31067 & 0.27116 & 0.20936 \\
\hline $\mathrm{O}$ & 1.66413 & -2.04027 & 0.10528 \\
\hline $\mathrm{C}$ & 3.54433 & -0.57103 & -0.01310 \\
\hline $\mathrm{C}$ & 3.94259 & 0.69043 & -0.46154 \\
\hline $\mathrm{C}$ & 4.45301 & -1.63367 & -0.05771 \\
\hline $\mathrm{C}$ & 5.23301 & 0.88423 & -0.95589 \\
\hline $\mathrm{H}$ & 3.24219 & 1.51442 & -0.42727 \\
\hline $\mathrm{C}$ & 5.74146 & -1.43765 & -0.55083 \\
\hline $\mathrm{H}$ & 4.14710 & -2.61420 & 0.28629 \\
\hline $\mathrm{C}$ & 6.13540 & -0.17714 & -1.00177 \\
\hline $\mathrm{H}$ & 5.53028 & 1.86656 & -1.30570 \\
\hline $\mathrm{H}$ & 6.43683 & -2.26907 & -0.58402 \\
\hline $\mathrm{H}$ & 7.13791 & -0.02466 & -1.38584 \\
\hline $\mathrm{O}$ & -0.43133 & 2.46371 & 1.08998 \\
\hline $\mathrm{H}$ & -0.55118 & 3.23317 & 0.47051 \\
\hline $\mathrm{O}$ & -2.37553 & 1.14427 & 2.37731 \\
\hline $\mathrm{H}$ & -1.81418 & 1.91478 & 2.55691 \\
\hline $\mathrm{O}$ & -3.16514 & -0.47482 & -0.70869 \\
\hline $\mathrm{C}$ & -3.92401 & -1.63066 & -1.12254 \\
\hline $\mathrm{H}$ & -3.65294 & -1.81510 & -2.16350 \\
\hline $\mathrm{H}$ & -3.60816 & -2.49666 & -0.53132 \\
\hline
\end{tabular}




$\begin{array}{llll}\mathrm{C} & -5.40164 & -1.39750 & -0.99598 \\ \mathrm{H} & -5.77051 & -1.15746 & -0.00101 \\ \mathrm{C} & -6.25499 & -1.47861 & -2.01473 \\ \mathrm{H} & -5.91735 & -1.71342 & -3.02007 \\ \mathrm{H} & -7.31907 & -1.31917 & -1.88012 \\ \mathrm{~N} & -0.75488 & 4.55057 & -0.64285 \\ \mathrm{C} & -0.88996 & 5.41644 & -1.42084\end{array}$

XYZ coordinates for the B3LYP/6-311++G(d,p)/PCM $\left(\mathrm{CH}_{2} \mathrm{Cl}_{2}\right)$ optimized geometry of $\mathbf{2}_{\mathrm{ax}}-\mathrm{N}$

$\begin{array}{lrrr}\mathrm{C} & 0.24956 & 0.56490 & 0.20472 \\ \mathrm{C} & -0.18551 & -0.83574 & 0.64731 \\ \mathrm{C} & 0.81637 & -1.36609 & 1.66632 \\ \mathrm{C} & 2.47450 & -0.00193 & 0.67120 \\ \mathrm{H} & 0.24833 & 1.23443 & 1.07573 \\ \mathrm{H} & 0.77635 & -0.76579 & 2.58485 \\ \mathrm{H} & 0.62585 & -2.40982 & 1.91570 \\ \mathrm{H} & 2.40255 & 0.66522 & 1.54743 \\ \mathrm{H} & -0.18701 & -1.49818 & -0.22522 \\ \mathrm{C} & -0.71377 & 1.10963 & -0.84296 \\ \mathrm{C} & -2.14871 & 1.04680 & -0.27418 \\ \mathrm{C} & -2.48321 & -0.33287 & 0.32712 \\ \mathrm{H} & -3.38666 & -0.25355 & 0.93751 \\ \mathrm{H} & -0.64325 & 0.49818 & -1.74551 \\ \mathrm{H} & -2.85958 & 1.23331 & -1.08554 \\ \mathrm{O} & -1.48528 & -0.79351 & 1.23347 \\ \mathrm{O} & 1.58116 & 0.47654 & -0.31722 \\ \mathrm{O} & 2.12804 & -1.31220 & 1.09097 \\ \mathrm{C} & 3.88500 & -0.00596 & 0.12474 \\ \mathrm{C} & 4.83502 & -0.89764 & 0.63172 \\ \mathrm{C} & 4.26699 & 0.92088 & -0.84953 \\ \mathrm{C} & 6.14842 & -0.86692 & 0.16455 \\ \mathrm{H} & 4.54268 & -1.61824 & 1.38476 \\ \mathrm{C} & 5.58119 & 0.94978 & -1.31511 \\ \mathrm{H} & 3.53398 & 1.61194 & -1.24537 \\ \mathrm{C} & 6.52573 & 0.05668 & -0.80997 \\ \mathrm{H} & 6.87588 & -1.56622 & 0.56168 \\ \mathrm{H} & 5.86530 & 1.66999 & -2.07430 \\ \mathrm{H} & 7.54715 & 0.07986 & -1.17315 \\ \mathrm{O} & -0.40805 & 2.44589 & -1.22151 \\ \mathrm{H} & -0.82194 & 3.00370 & -0.54439 \\ \mathrm{O} & -2.24628 & 2.06088 & 0.71084 \\ \mathrm{H} & -3.16070 & 2.45363 & 0.68524\end{array}$




$\begin{array}{lrrr}\mathrm{O} & -2.66328 & -1.22663 & -0.74772 \\ \mathrm{C} & -3.29646 & -2.47865 & -0.40788 \\ \mathrm{H} & -2.86412 & -3.23139 & -1.06985 \\ \mathrm{H} & -3.03470 & -2.74391 & 0.62194 \\ \mathrm{C} & -4.78500 & -2.40994 & -0.58793 \\ \mathrm{H} & -5.30652 & -1.64974 & -0.01040 \\ \mathrm{C} & -5.47326 & -3.21863 & -1.39105 \\ \mathrm{H} & -4.98051 & -3.98455 & -1.98321 \\ \mathrm{H} & -6.55149 & -3.14768 & -1.48142 \\ \mathrm{~N} & -4.74383 & 3.14325 & 0.59584 \\ \mathrm{C} & -5.80774 & 3.63376 & 0.56790\end{array}$

XYZ coordinates for the B3LYP/6-311++G(d,p)/PCM $\left(\mathrm{CH}_{2} \mathrm{Cl}_{2}\right)$ optimized geometry of $\mathbf{2}_{\mathrm{ax}}, \mathbf{3}_{\mathrm{eq}}-\mathrm{C}$

$\begin{array}{lrrr}\mathrm{C} & -0.00863 & 0.43240 & -0.23023 \\ \mathrm{C} & 0.54481 & -0.92786 & -0.67563 \\ \mathrm{C} & -0.42220 & -1.55337 & -1.67407 \\ \mathrm{C} & -2.17699 & -0.34476 & -0.63962 \\ \mathrm{H} & -0.09934 & 1.09529 & -1.10039 \\ \mathrm{H} & -0.45633 & -0.95549 & -2.59440 \\ \mathrm{H} & -0.13932 & -2.57579 & -1.92463 \\ \mathrm{H} & -2.18782 & 0.32581 & -1.51588 \\ \mathrm{H} & 0.61189 & -1.57835 & 0.20381 \\ \mathrm{C} & 0.94049 & 1.05465 & 0.78892 \\ \mathrm{C} & 2.33746 & 1.15816 & 0.13363 \\ \mathrm{C} & 2.79575 & -0.20393 & -0.41347 \\ \mathrm{H} & 3.67451 & -0.06113 & -1.04766 \\ \mathrm{H} & 1.01931 & 0.37505 & 1.64268 \\ \mathrm{H} & 3.05717 & 1.47258 & 0.89849 \\ \mathrm{O} & 1.82981 & -0.79062 & -1.28019 \\ \mathrm{O} & -1.31000 & 0.21127 & 0.32763 \\ \mathrm{O} & -1.72147 & -1.62038 & -1.07258 \\ \mathrm{C} & -3.56937 & -0.48797 & -0.06660 \\ \mathrm{C} & -3.96718 & 0.25733 & 1.04598 \\ \mathrm{C} & -4.49109 & -1.33637 & -0.68882 \\ \mathrm{C} & -5.26933 & 0.14808 & 1.53508 \\ \mathrm{H} & -3.25679 & 0.91672 & 1.52711 \\ \mathrm{C} & -5.79145 & -1.44342 & -0.19909 \\ \mathrm{H} & -4.18632 & -1.91613 & -1.55134 \\ \mathrm{C} & -6.18453 & -0.70138 & 0.91529 \\ \mathrm{H} & -5.56642 & 0.72824 & 2.40167 \\ \mathrm{H} & -6.49690 & -2.10657 & -0.68745 \\ \mathrm{H} & -7.19625 & -0.78474 & 1.29637 \\ \mathrm{O} & 0.49217 & 2.29027 & 1.32095 \\ \mathrm{H} & 0.67626 & 3.02832 & 0.70252\end{array}$




$\begin{array}{lrrr}\mathrm{O} & 2.35812 & 2.04680 & -0.97486 \\ \mathrm{H} & 2.05598 & 2.94423 & -0.70296 \\ \mathrm{O} & 3.08284 & -1.02999 & 0.69045 \\ \mathrm{C} & 3.80652 & -2.23959 & 0.37992 \\ \mathrm{H} & 3.46908 & -2.98992 & 1.09734 \\ \mathrm{H} & 3.52320 & -2.57788 & -0.62226 \\ \mathrm{C} & 5.29073 & -2.04052 & 0.48540 \\ \mathrm{H} & 5.72295 & -1.27314 & -0.15326 \\ \mathrm{C} & 6.07737 & -2.74829 & 1.29353 \\ \mathrm{H} & 5.67438 & -3.51925 & 1.94399 \\ \mathrm{H} & 7.14917 & -2.58782 & 1.32930 \\ \mathrm{~N} & 1.14362 & 5.84210 & -0.47158 \\ \mathrm{C} & 1.27005 & 4.69127 & -0.31243\end{array}$

XYZ coordinates for the B3LYP/6-311++G(d,p)/PCM $\left(\mathrm{CH}_{2} \mathrm{Cl}_{2}\right)$ optimized geometry of $\mathbf{3}_{\text {eq }}-\mathbf{C}$

$\begin{array}{lrrr}\mathrm{C} & 0.01715 & 0.11007 & 0.81657 \\ \mathrm{C} & -0.58341 & -1.21019 & 0.32601 \\ \mathrm{C} & 0.37723 & -2.34685 & 0.65718 \\ \mathrm{C} & 2.16220 & -0.79414 & 0.56859 \\ \mathrm{H} & 0.13610 & 0.06557 & 1.90806 \\ \mathrm{H} & 0.45227 & -2.47352 & 1.74560 \\ \mathrm{H} & 0.05774 & -3.28879 & 0.21145 \\ \mathrm{H} & 2.21061 & -0.84268 & 1.67004 \\ \mathrm{H} & -0.71515 & -1.16169 & -0.76029 \\ \mathrm{C} & -0.89448 & 1.27649 & 0.46742 \\ \mathrm{C} & -2.33182 & 0.96811 & 0.96456 \\ \mathrm{C} & -2.81089 & -0.45627 & 0.65292 \\ \mathrm{H} & -3.65999 & -0.70244 & 1.29697 \\ \mathrm{H} & -0.90957 & 1.40623 & -0.62052 \\ \mathrm{H} & -3.02500 & 1.66382 & 0.47905 \\ \mathrm{O} & -1.83859 & -1.44861 & 0.96261 \\ \mathrm{O} & 1.30568 & 0.26996 & 0.21260 \\ \mathrm{O} & 1.66182 & -2.04074 & 0.10092 \\ \mathrm{C} & 3.54031 & -0.56964 & -0.01296 \\ \mathrm{C} & 3.93577 & 0.69163 & -0.46433 \\ \mathrm{C} & 4.45156 & -1.63023 & -0.05452 \\ \mathrm{C} & 5.22605 & 0.88728 & -0.95838 \\ \mathrm{H} & 3.23347 & 1.51409 & -0.43215 \\ \mathrm{C} & 5.73977 & -1.43242 & -0.54749 \\ \mathrm{H} & 4.14780 & -2.61066 & 0.29172 \\ \mathrm{C} & 6.13094 & -0.17208 & -1.00137 \\ \mathrm{H} & 5.52115 & 1.86945 & -1.31047 \\ \mathrm{H} & 6.43712 & -2.26227 & -0.57833\end{array}$




$\begin{array}{lrrr}\mathrm{H} & 7.13327 & -0.01812 & -1.38529 \\ \mathrm{O} & -0.44359 & 2.45779 & 1.10522 \\ \mathrm{H} & -0.53777 & 3.23170 & 0.47391 \\ \mathrm{O} & -2.38807 & 1.13584 & 2.37964 \\ \mathrm{H} & -1.82526 & 1.90537 & 2.55997 \\ \mathrm{O} & -3.17094 & -0.48231 & -0.70821 \\ \mathrm{C} & -3.92619 & -1.64014 & -1.12285 \\ \mathrm{H} & -3.65779 & -1.82046 & -2.16522 \\ \mathrm{H} & -3.60465 & -2.50647 & -0.53517 \\ \mathrm{C} & -5.40447 & -1.41405 & -0.99081 \\ \mathrm{H} & -5.77109 & -1.17755 & 0.00583 \\ \mathrm{C} & -6.26100 & -1.49752 & -2.00671 \\ \mathrm{H} & -5.92579 & -1.72910 & -3.01361 \\ \mathrm{H} & -7.32537 & -1.34347 & -1.86810 \\ \mathrm{~N} & -0.77348 & 5.53950 & -1.42371 \\ \mathrm{C} & -0.69673 & 4.62479 & -0.69878\end{array}$

XYZ coordinates for the B3LYP/6-311++G(d,p)/PCM $\left(\mathrm{CH}_{2} \mathrm{Cl}_{2}\right)$ optimized geometry of $\mathbf{2}_{\mathrm{ax}}-\mathrm{C}$

$\begin{array}{lrrr}\mathrm{C} & 0.25576 & 0.55484 & 0.20576 \\ \mathrm{C} & -0.16692 & -0.85113 & 0.64344 \\ \mathrm{C} & 0.84078 & -1.37709 & 1.65902 \\ \mathrm{C} & 2.48556 & 0.00612 & 0.66821 \\ \mathrm{H} & 0.25003 & 1.22074 & 1.07949 \\ \mathrm{H} & 0.79635 & -0.78094 & 2.58007 \\ \mathrm{H} & 0.65952 & -2.42346 & 1.90426 \\ \mathrm{H} & 2.40732 & 0.66882 & 1.54730 \\ \mathrm{H} & -0.16428 & -1.51003 & -0.23178 \\ \mathrm{C} & -0.71378 & 1.09669 & -0.83761 \\ \mathrm{C} & -2.14656 & 1.02169 & -0.26375 \\ \mathrm{C} & -2.46930 & -0.36370 & 0.33073 \\ \mathrm{H} & -3.37164 & -0.29405 & 0.94388 \\ \mathrm{H} & -0.64121 & 0.48992 & -1.74320 \\ \mathrm{H} & -2.86167 & 1.20650 & -1.07246 \\ \mathrm{O} & -1.46589 & -0.82229 & 1.23217 \\ \mathrm{O} & 1.58765 & 0.47979 & -0.31786 \\ \mathrm{O} & 2.15147 & -1.30933 & 1.08289 \\ \mathrm{C} & 3.89649 & 0.01674 & 0.12304 \\ \mathrm{C} & 4.26602 & 0.93276 & -0.86598 \\ \mathrm{C} & 4.85935 & -0.85114 & 0.64711 \\ \mathrm{C} & 5.58078 & 0.97428 & -1.32935 \\ \mathrm{H} & 3.52323 & 1.60565 & -1.27461 \\ \mathrm{C} & 6.17314 & -0.80767 & 0.18239 \\ \mathrm{H} & 4.57673 & -1.56341 & 1.41180\end{array}$




$\begin{array}{lrrr}\mathrm{C} & 6.53806 & 0.10500 & -0.80715 \\ \mathrm{H} & 5.85530 & 1.68582 & -2.10017 \\ \mathrm{H} & 6.91064 & -1.48835 & 0.59307 \\ \mathrm{H} & 7.55984 & 0.13815 & -1.16853 \\ \mathrm{O} & -0.41870 & 2.43704 & -1.21023 \\ \mathrm{H} & -0.83618 & 2.98748 & -0.52905 \\ \mathrm{O} & -2.24957 & 2.02909 & 0.72595 \\ \mathrm{H} & -3.16777 & 2.43314 & 0.68884 \\ \mathrm{O} & -2.64589 & -1.25373 & -0.74809 \\ \mathrm{C} & -3.26774 & -2.51227 & -0.41208 \\ \mathrm{H} & -2.83397 & -3.25782 & -1.08124 \\ \mathrm{H} & -2.99775 & -2.78185 & 0.61451 \\ \mathrm{C} & -4.75789 & -2.45382 & -0.58251 \\ \mathrm{H} & -5.28143 & -1.70026 & 0.00187 \\ \mathrm{C} & -5.44534 & -3.26387 & -1.38496 \\ \mathrm{H} & -4.95078 & -4.02339 & -1.98382 \\ \mathrm{H} & -6.52463 & -3.20054 & -1.46807 \\ \mathrm{~N} & -5.88533 & 3.66921 & 0.54699 \\ \mathrm{C} & -4.82557 & 3.17571 & 0.58040\end{array}$

$\mathrm{XYZ}$ coordinates for the $\mathrm{B} 3 \mathrm{LYP} / 6-311++\mathrm{G}(\mathrm{d}, \mathrm{p}) / \mathrm{PCM}\left(\mathrm{CH}_{2} \mathrm{Cl}_{2}\right)$ optimized geometry of $\mathbf{2}_{\mathrm{ax}}, \mathbf{3}_{\mathrm{eq}}-\mathbf{F}$

$\begin{array}{lrrr}\mathrm{C} & 0.00276 & 0.59788 & -0.28068 \\ \mathrm{C} & 0.59796 & -0.76250 & -0.66640 \\ \mathrm{C} & -0.34611 & -1.46271 & -1.63668 \\ \mathrm{C} & -2.14048 & -0.27041 & -0.65640 \\ \mathrm{H} & -0.10962 & 1.22053 & -1.17790 \\ \mathrm{H} & -0.39802 & -0.90754 & -2.58265 \\ \mathrm{H} & -0.03015 & -2.48569 & -1.84203 \\ \mathrm{H} & -2.17320 & 0.36192 & -1.56048 \\ \mathrm{H} & 0.68165 & -1.37088 & 0.24167 \\ \mathrm{C} & 0.92828 & 1.29472 & 0.71335 \\ \mathrm{C} & 2.32348 & 1.41618 & 0.04417 \\ \mathrm{C} & 2.82465 & 0.04301 & -0.43446 \\ \mathrm{H} & 3.69970 & 0.18229 & -1.07483 \\ \mathrm{H} & 1.03834 & 0.63962 & 1.58438 \\ \mathrm{H} & 3.02916 & 1.78136 & 0.80243 \\ \mathrm{O} & 1.88008 & -0.61675 & -1.27415 \\ \mathrm{O} & -1.29335 & 0.35663 & 0.28579 \\ \mathrm{O} & -1.64426 & -1.54586 & -1.03459 \\ \mathrm{C} & -3.52636 & -0.42218 & -0.06849 \\ \mathrm{C} & -4.35394 & -1.47993 & -0.45605 \\ \mathrm{C} & -4.01219 & 0.53363 & 0.82895 \\ \mathrm{C} & -5.64819 & -1.58371 & 0.05341\end{array}$




$\begin{array}{lrrr}\mathrm{H} & -3.98173 & -2.22325 & -1.14929 \\ \mathrm{C} & -5.30653 & 0.42843 & 1.33633 \\ \mathrm{H} & -3.37198 & 1.35191 & 1.13298 \\ \mathrm{C} & -6.12867 & -0.63029 & 0.95048 \\ \mathrm{H} & -6.27988 & -2.41114 & -0.25057 \\ \mathrm{H} & -5.67098 & 1.17376 & 2.03455 \\ \mathrm{H} & -7.13506 & -0.71161 & 1.34596 \\ \mathrm{O} & 0.43537 & 2.52462 & 1.20102 \\ \mathrm{H} & 0.58635 & 3.25618 & 0.53681 \\ \mathrm{O} & 2.33079 & 2.25286 & -1.09746 \\ \mathrm{H} & 1.87639 & 3.12383 & -0.89390 \\ \mathrm{O} & 3.13850 & -0.72729 & 0.70382 \\ \mathrm{C} & 3.91232 & -1.91618 & 0.44566 \\ \mathrm{H} & 3.58926 & -2.65961 & 1.17716 \\ \mathrm{H} & 3.66574 & -2.29486 & -0.55199 \\ \mathrm{C} & 5.38518 & -1.65587 & 0.57687 \\ \mathrm{H} & 5.79954 & -0.88756 & -0.07252 \\ \mathrm{C} & 6.18183 & -2.30909 & 1.42045 \\ \mathrm{H} & 5.79597 & -3.07829 & 2.08333 \\ \mathrm{H} & 7.24514 & -2.10347 & 1.47503 \\ \mathrm{~F} & 1.02249 & 4.35145 & -0.50628\end{array}$

XYZ coordinates for the B3LYP/6-311++G(d,p)/PCM $\left(\mathrm{CH}_{2} \mathrm{Cl}_{2}\right)$ optimized geometry of $\mathbf{3}_{\text {eq }}-\mathbf{F}$

$\begin{array}{lrrr}\mathrm{C} & -0.07072 & 0.45005 & 0.67273 \\ \mathrm{C} & -0.73406 & -0.91218 & 0.46760 \\ \mathrm{C} & 0.15897 & -1.99506 & 1.06240 \\ \mathrm{C} & 2.02758 & -0.59135 & 0.67102 \\ \mathrm{H} & 0.03632 & 0.63936 & 1.74980 \\ \mathrm{H} & 0.21457 & -1.87984 & 2.15339 \\ \mathrm{H} & -0.20521 & -2.99587 & 0.82955 \\ \mathrm{H} & 2.06940 & -0.39903 & 1.75710 \\ \mathrm{H} & -0.85199 & -1.09761 & -0.60567 \\ \mathrm{C} & -0.90943 & 1.56791 & 0.05929 \\ \mathrm{C} & -2.36381 & 1.44470 & 0.57653 \\ \mathrm{C} & -2.91917 & 0.01385 & 0.58034 \\ \mathrm{H} & -3.78309 & -0.03770 & 1.24958 \\ \mathrm{H} & -0.90909 & 1.44453 & -1.03119 \\ \mathrm{H} & -3.01228 & 2.04863 & -0.06794 \\ \mathrm{O} & -2.00809 & -0.94020 & 1.11373 \\ \mathrm{O} & 1.23141 & 0.40821 & 0.07581 \\ \mathrm{O} & 1.46449 & -1.88577 & 0.48194 \\ \mathrm{C} & 3.41748 & -0.56864 & 0.07472 \\ \mathrm{C} & 4.27257 & -1.65822 & 0.27096\end{array}$




$\begin{array}{lrrr}\text { C } & 3.87761 & 0.54691 & -0.62932 \\ \mathrm{C} & 5.57014 & -1.63479 & -0.23668 \\ \mathrm{H} & 3.91795 & -2.52585 & 0.81405 \\ \mathrm{C} & 5.17720 & 0.56742 & -1.13718 \\ \mathrm{H} & 3.21788 & 1.39155 & -0.78122 \\ \mathrm{C} & 6.02633 & -0.52099 & -0.94298 \\ \mathrm{H} & 6.22394 & -2.48598 & -0.08162 \\ \mathrm{H} & 5.52316 & 1.43612 & -1.68617 \\ \mathrm{H} & 7.03585 & -0.50272 & -1.33853 \\ \mathrm{O} & -0.44814 & 2.84342 & 0.42637 \\ \mathrm{H} & 0.15165 & 3.26332 & -0.32637 \\ \mathrm{O} & -2.42893 & 1.93165 & 1.91706 \\ \mathrm{H} & -1.81503 & 2.68376 & 1.92809 \\ \mathrm{O} & -3.28007 & -0.29411 & -0.74733 \\ \mathrm{C} & -4.09100 & -1.47677 & -0.90281 \\ \mathrm{H} & -3.82610 & -1.90395 & -1.87174 \\ \mathrm{H} & -3.81925 & -2.20175 & -0.12820 \\ \mathrm{C} & -5.55664 & -1.15474 & -0.85190 \\ \mathrm{H} & -5.91183 & -0.66156 & 0.05051 \\ \mathrm{C} & -6.41555 & -1.44715 & -1.82632 \\ \mathrm{H} & -6.09127 & -1.93626 & -2.74038 \\ \mathrm{H} & -7.47133 & -1.21398 & -1.74365 \\ \mathrm{~F} & 0.91726 & 3.84928 & -1.30227 \\ & & & \end{array}$

$\mathrm{XYZ}$ coordinates for the B3LYP/6-311++G(d,p)/PCM $\left(\mathrm{CH}_{2} \mathrm{Cl}_{2}\right)$ optimized geometry of $\mathbf{2}_{\text {ax }}-\mathbf{F}$

$\begin{array}{lrrr}\mathrm{C} & 0.14557 & 0.71762 & 0.12530 \\ \mathrm{C} & -0.37293 & -0.56414 & 0.78437 \\ \mathrm{C} & 0.59560 & -0.97932 & 1.88444 \\ \mathrm{C} & 2.34371 & 0.09955 & 0.69179 \\ \mathrm{H} & 0.18369 & 1.51870 & 0.87609 \\ \mathrm{H} & 0.59539 & -0.23325 & 2.69027 \\ \mathrm{H} & 0.34111 & -1.95298 & 2.30350 \\ \mathrm{H} & 2.34544 & 0.90240 & 1.44488 \\ \mathrm{H} & -0.41494 & -1.35875 & 0.03082 \\ \mathrm{C} & -0.78203 & 1.14253 & -1.00576 \\ \mathrm{C} & -2.22123 & 1.26079 & -0.45142 \\ \mathrm{C} & -2.63663 & 0.02091 & 0.36664 \\ \mathrm{H} & -3.53079 & 0.25605 & 0.94994 \\ \mathrm{H} & -0.74125 & 0.39400 & -1.80106 \\ \mathrm{H} & -2.91488 & 1.33105 & -1.29846 \\ \mathrm{O} & -1.66684 & -0.35062 & 1.34425 \\ \mathrm{O} & 1.47175 & 0.46830 & -0.36324 \\ \mathrm{O} & 1.90808 & -1.10312 & 1.31986\end{array}$




$\begin{array}{lrrr}\mathrm{C} & 3.72816 & -0.12140 & 0.14027 \\ \mathrm{C} & 4.81602 & 0.55812 & 0.68950 \\ \mathrm{C} & 3.93649 & -1.01603 & -0.91458 \\ \mathrm{C} & 6.10338 & 0.34829 & 0.19282 \\ \mathrm{H} & 4.65870 & 1.25457 & 1.50641 \\ \mathrm{C} & 5.22025 & -1.22477 & -1.41180 \\ \mathrm{H} & 3.09311 & -1.54236 & -1.34502 \\ \mathrm{C} & 6.30677 & -0.54341 & -0.85857 \\ \mathrm{H} & 6.94243 & 0.88158 & 0.62527 \\ \mathrm{H} & 5.37511 & -1.91768 & -2.23131 \\ \mathrm{H} & 7.30562 & -0.70678 & -1.24763 \\ \mathrm{O} & -0.40268 & 2.38965 & -1.57686 \\ \mathrm{H} & -0.83789 & 3.05138 & -1.01288 \\ \mathrm{O} & -2.26821 & 2.43000 & 0.32970 \\ \mathrm{H} & -3.22692 & 2.84622 & 0.28996 \\ \mathrm{O} & -2.87939 & -1.03029 & -0.54349 \\ \mathrm{C} & -3.60761 & -2.15376 & -0.00760 \\ \mathrm{H} & -3.19517 & -3.04832 & -0.47922 \\ \mathrm{H} & -3.41905 & -2.22383 & 1.06908 \\ \mathrm{C} & -5.07702 & -2.03781 & -0.29203 \\ \mathrm{H} & -5.56958 & -1.14347 & 0.08348 \\ \mathrm{C} & -5.78040 & -2.95305 & -0.95573 \\ \mathrm{H} & -5.31415 & -3.85284 & -1.34706 \\ \mathrm{H} & -6.84500 & -2.83859 & -1.12711 \\ \mathrm{~F} & -4.49348 & 3.40298 & 0.23026\end{array}$

\section{Reference:}

(1) Belot, F.; Otter, A.; Fukuda, M.; Hindsgaul, O. Synlett 2003, 1315-1318.

(2) Chen, L.; Kong, F. Carbohydr. Res. 2002, 337, 1373-1380.

(3) Jacquinet, J.-C. Carbohydr. Res. 2004, 339, 349-359.

(4) Abbas, S. A.; Haines, A. H. Carbohydr. Res. 1975, 39, 358-363.

(5) Tanaka, S.-i.; Goi, T.; Tanaka, K.; Fukase, K. J. Carbohydr. Chem. 2007, 26, 369-394.

(6) Kumar, R.; Maulik, P. R.; Misra, A. K. Glycoconjugate J. 2008, 25, 511-519.

(7) Choudhury, A. K.; Roy, N. J. Carbohydr. Chem. 1997, 16, 1363-1371.

(8) Kajihara, Y.; Endo, T.; Ogasawara, H.; Kodama, H.; Hashimoto, H. Carbohydr. Res. 1995, 269, 273-294. 
${ }^{1} \mathrm{H}$ spectrum of compound $\mathbf{2 a}\left(400 \mathrm{MHz}, \mathrm{CDCl}_{3}\right)$

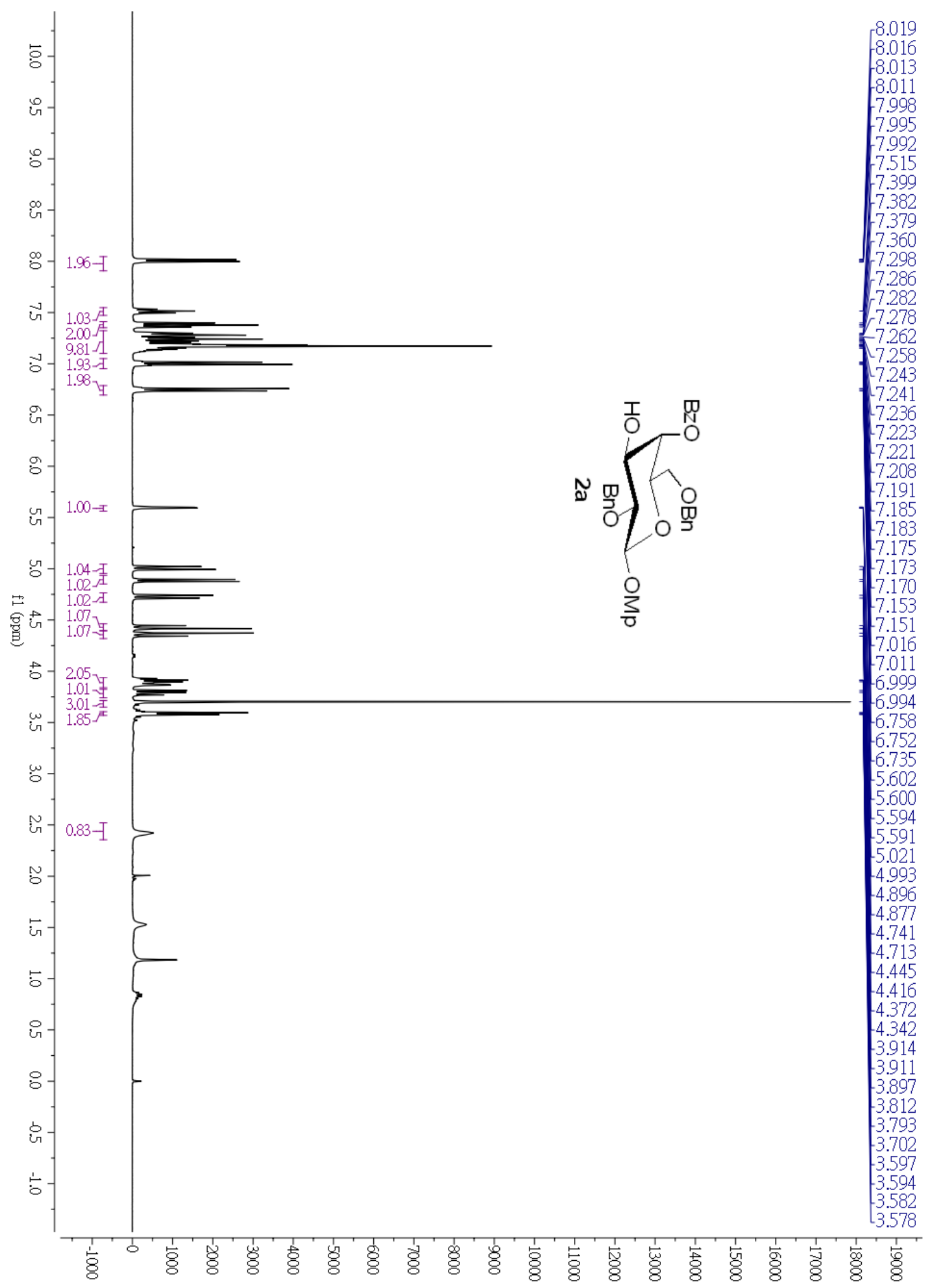


${ }^{1} \mathrm{H}$ spectrum of compound $\mathbf{3 a}\left(400 \mathrm{MHz}, \mathrm{CDCl}_{3}\right)$

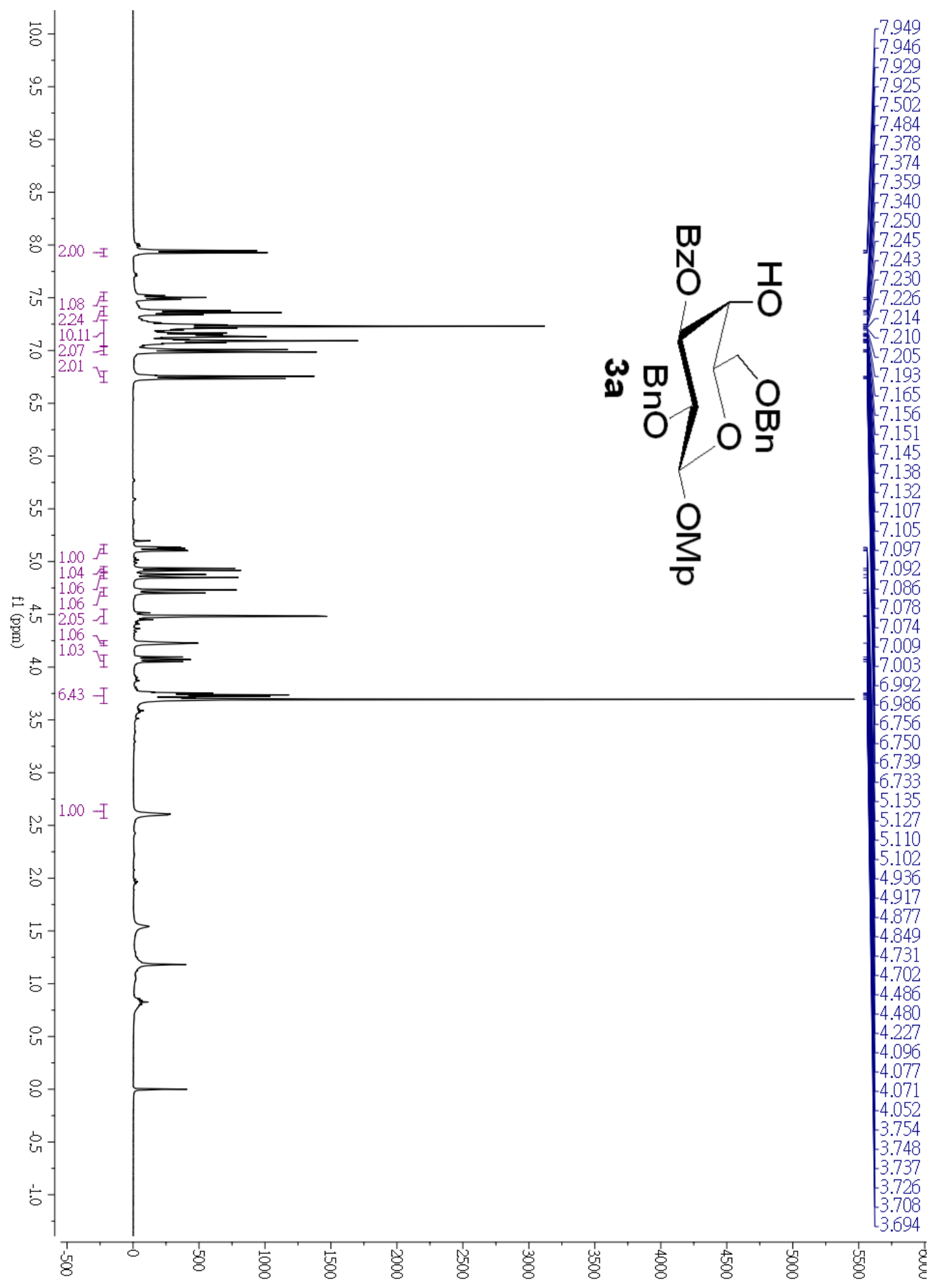


${ }^{1} \mathrm{H}-{ }^{1} \mathrm{H}$ COSY of compound $\mathbf{3 a}$

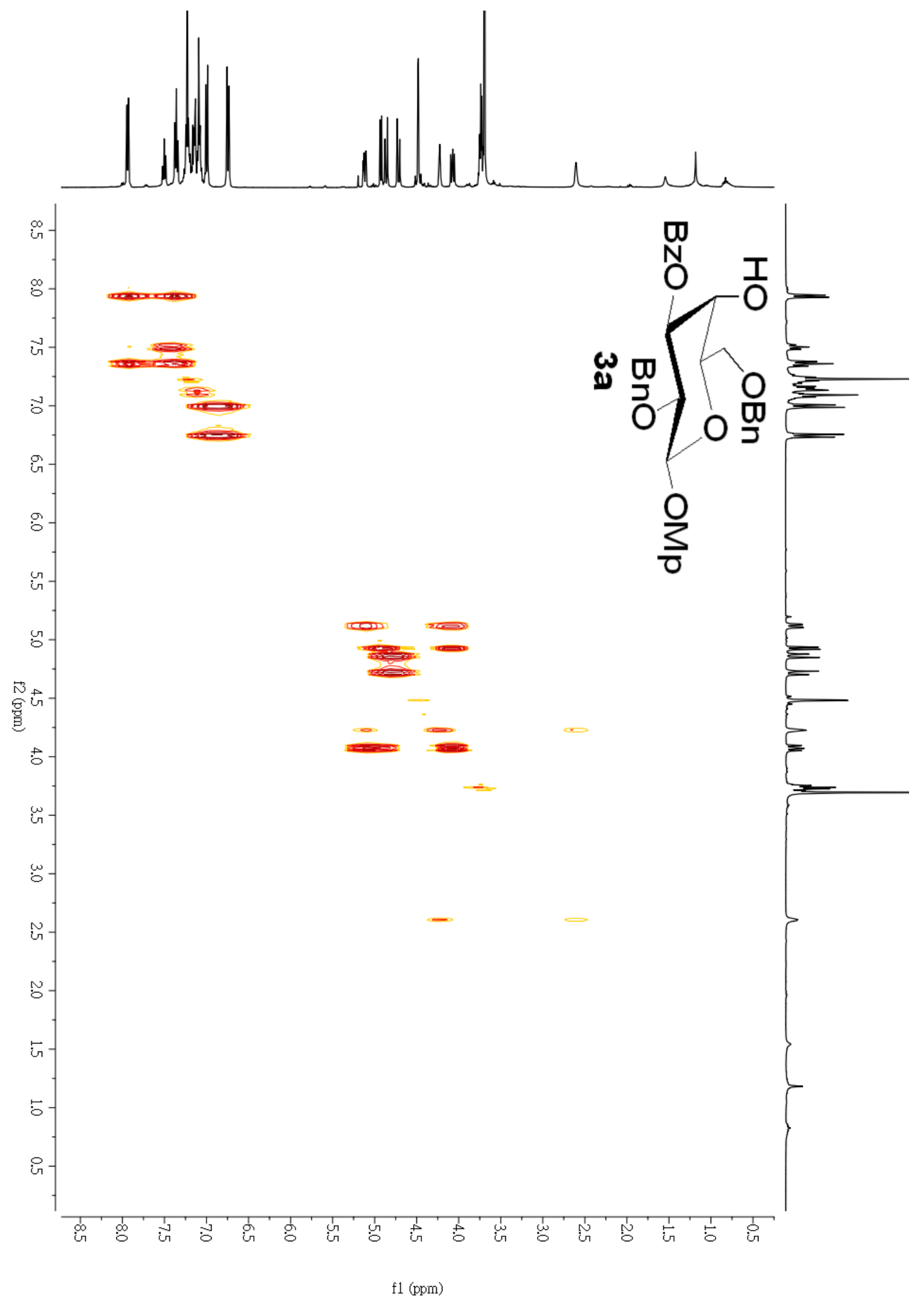


HSQC of compound 3a

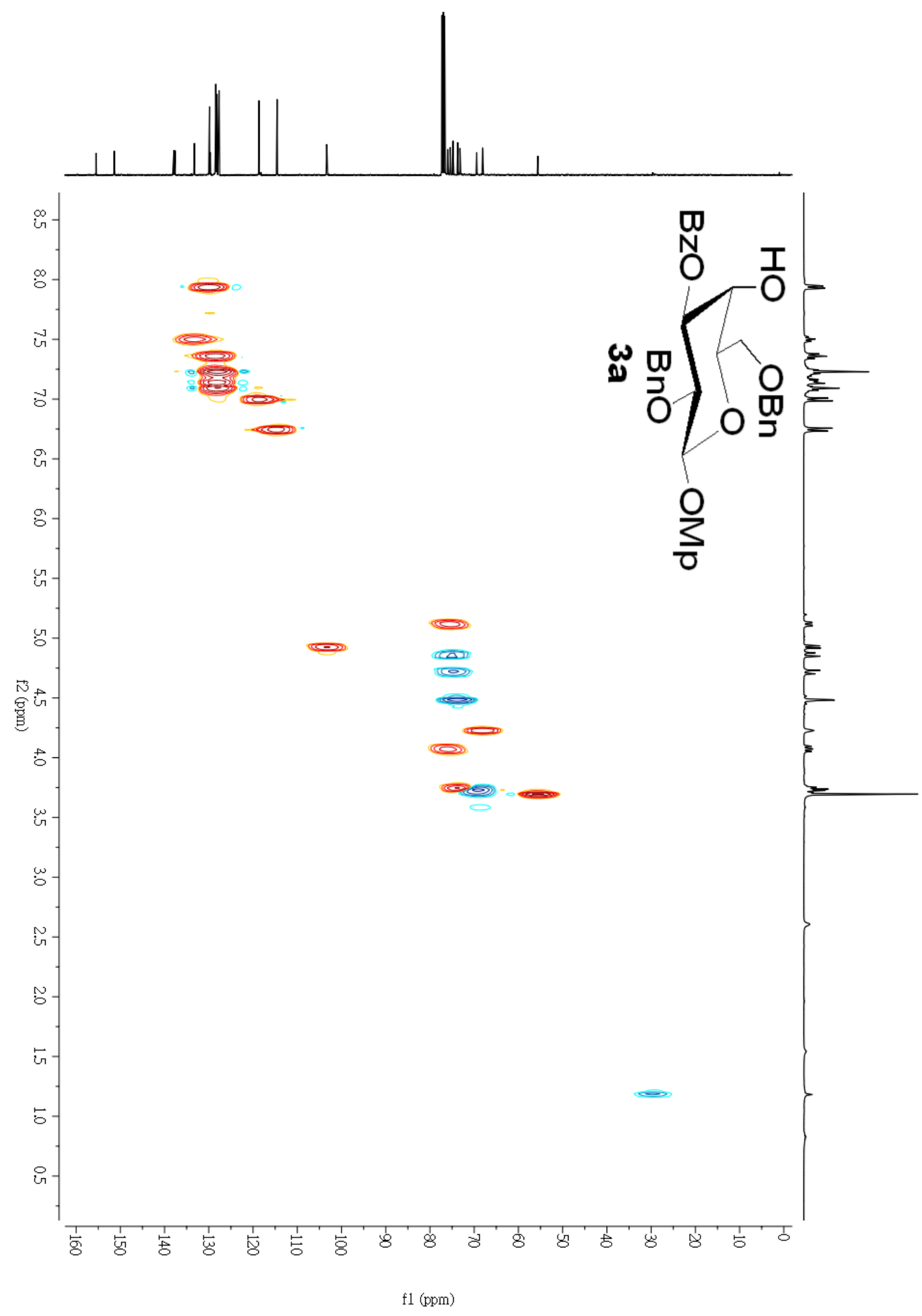


${ }^{13} \mathrm{C}$ spectrum of compound $\mathbf{3 a}\left(100 \mathrm{MHz}, \mathrm{CDCl}_{3}\right)$

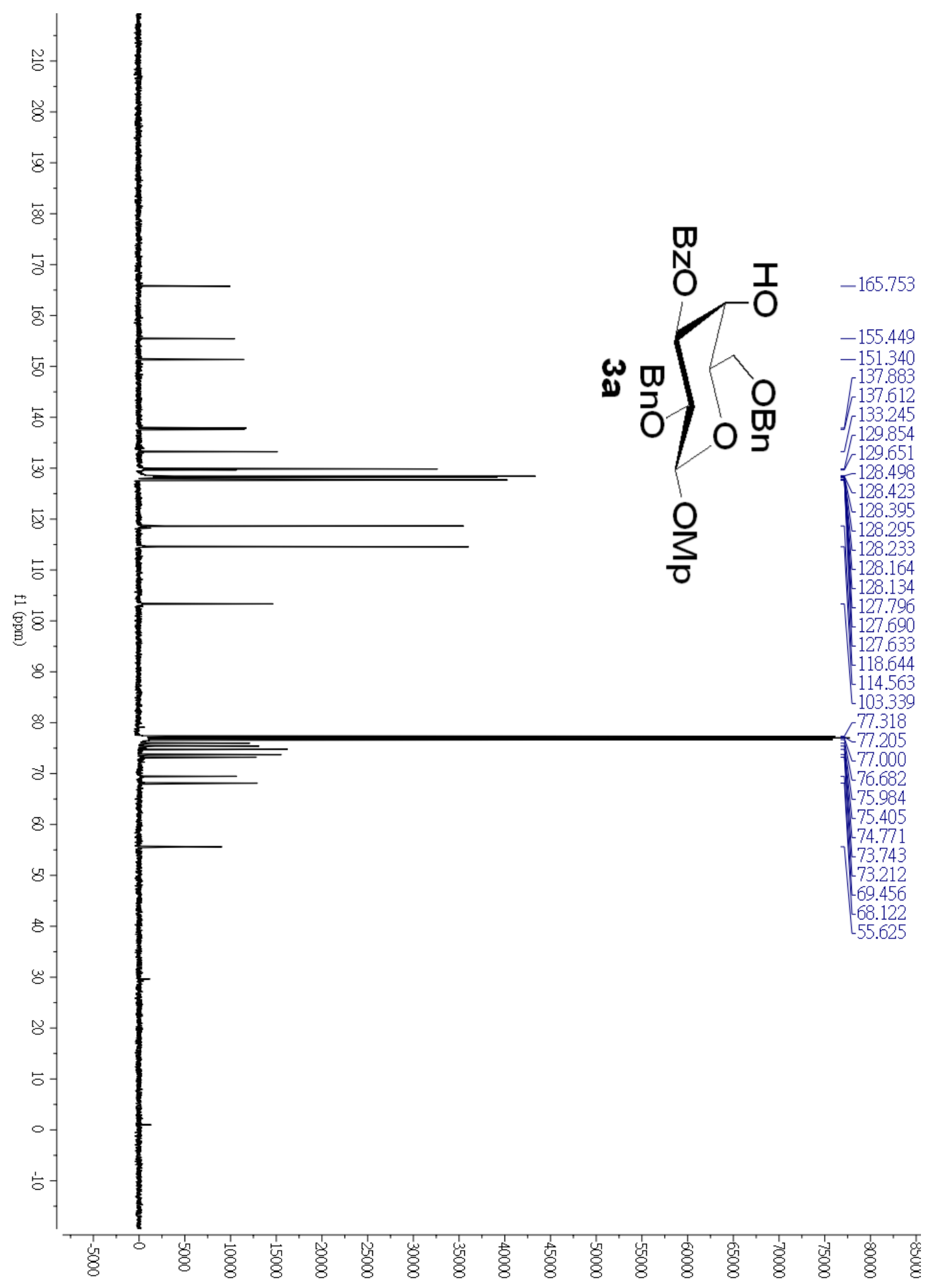


${ }^{1} \mathrm{H}$ spectrum of compound $\mathbf{2 b}\left(400 \mathrm{MHz}, \mathrm{CDCl}_{3}\right)$

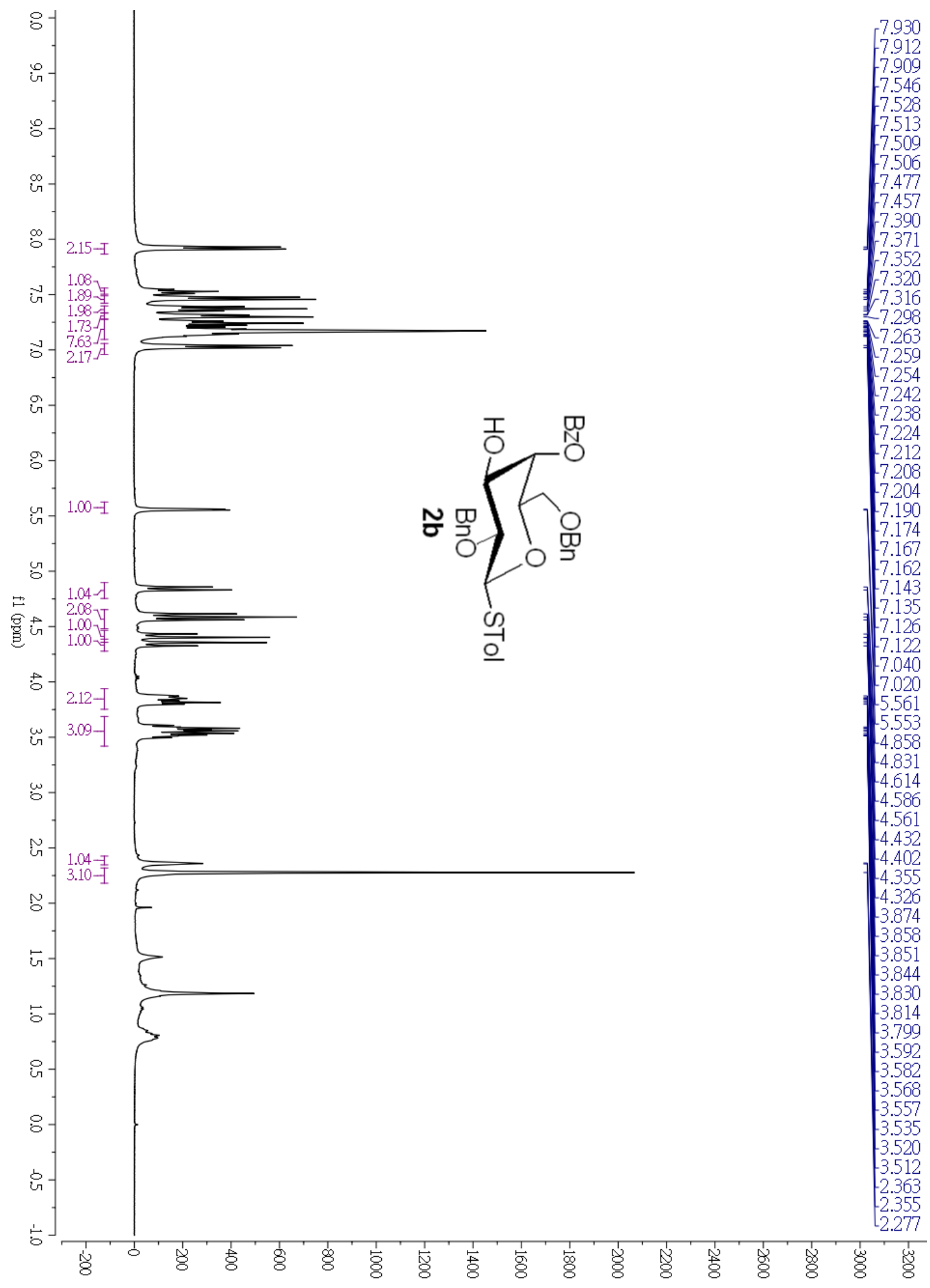


${ }^{1} \mathrm{H}-{ }^{1} \mathrm{H}$ COSY of compound $\mathbf{2 b}$

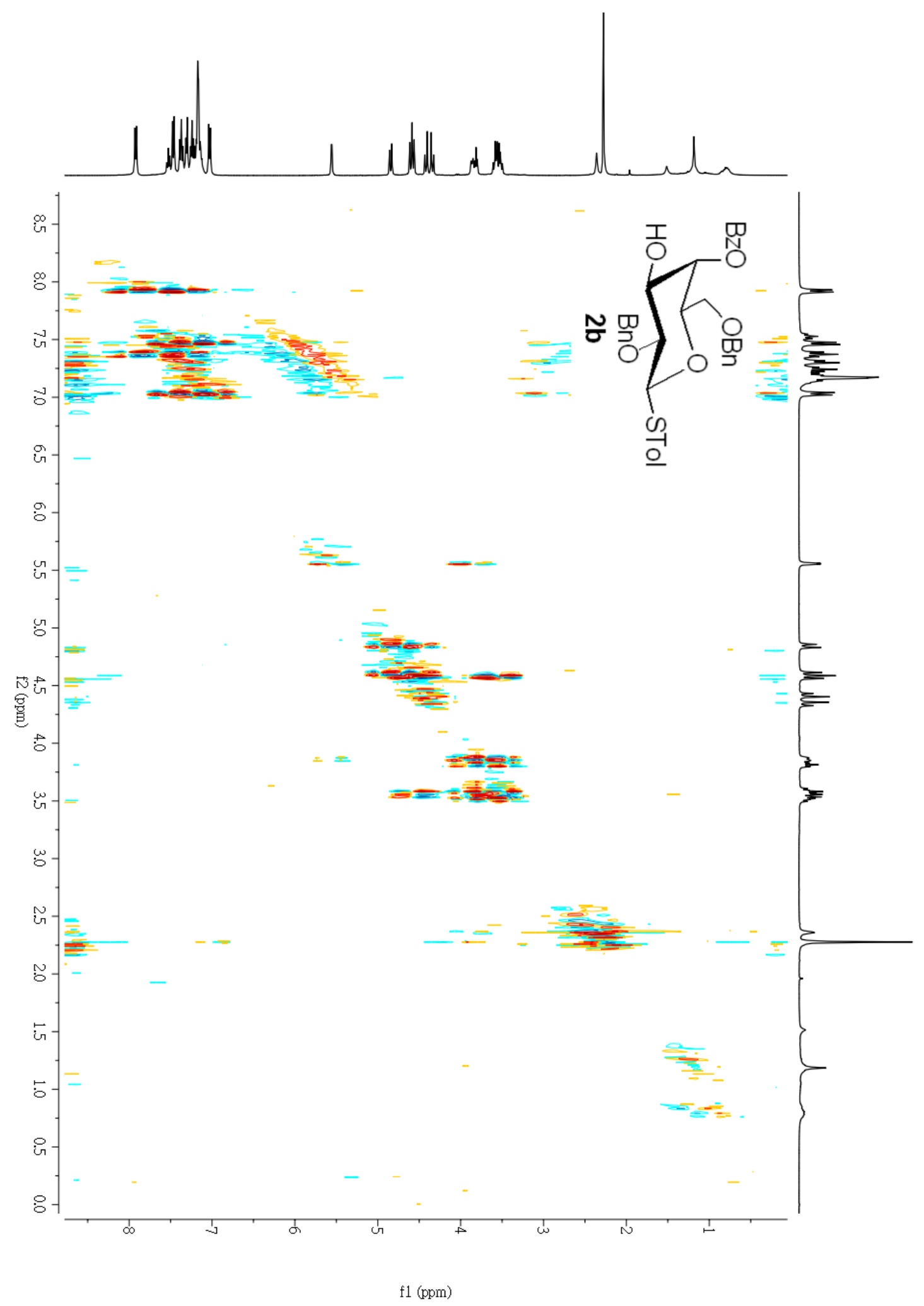




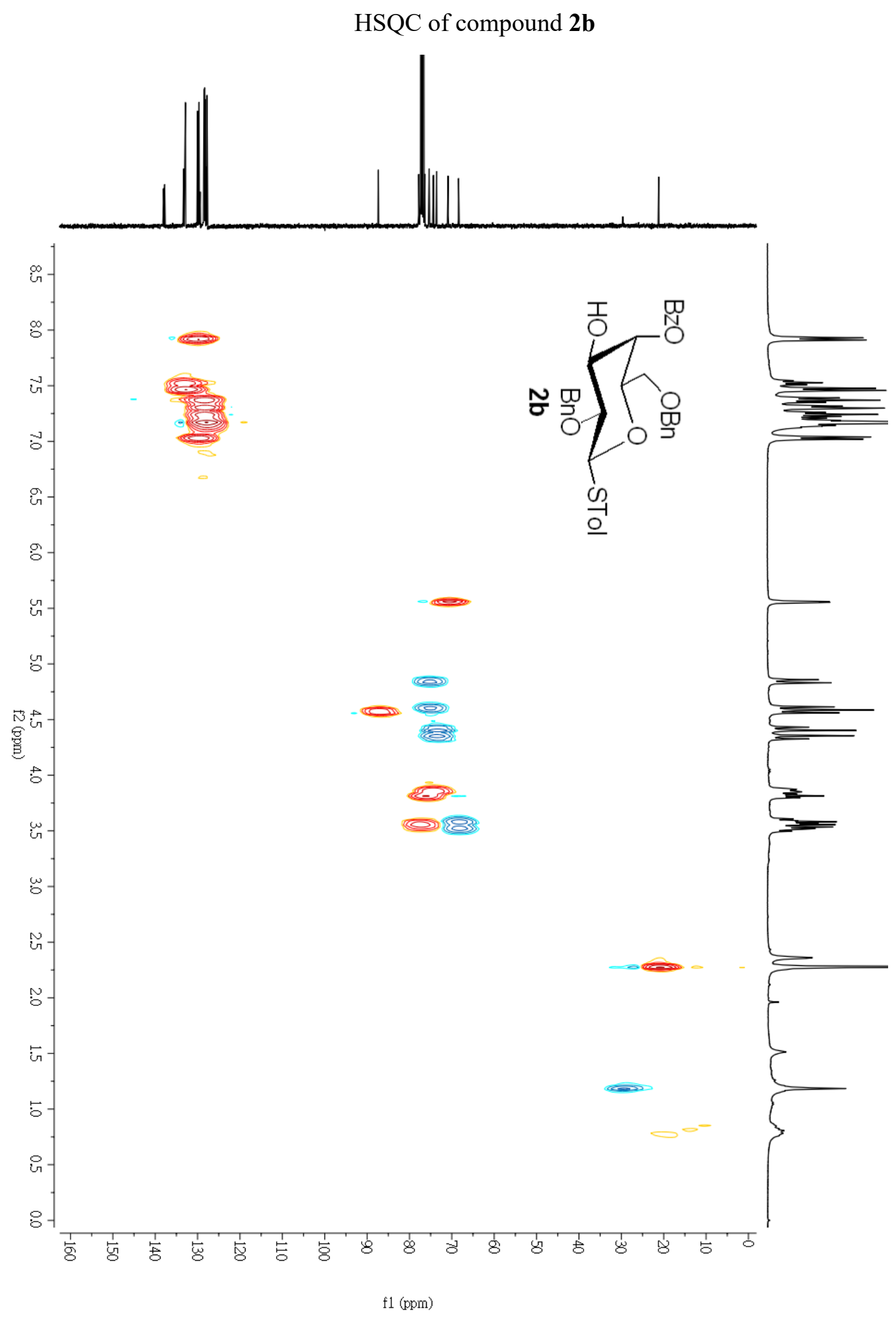




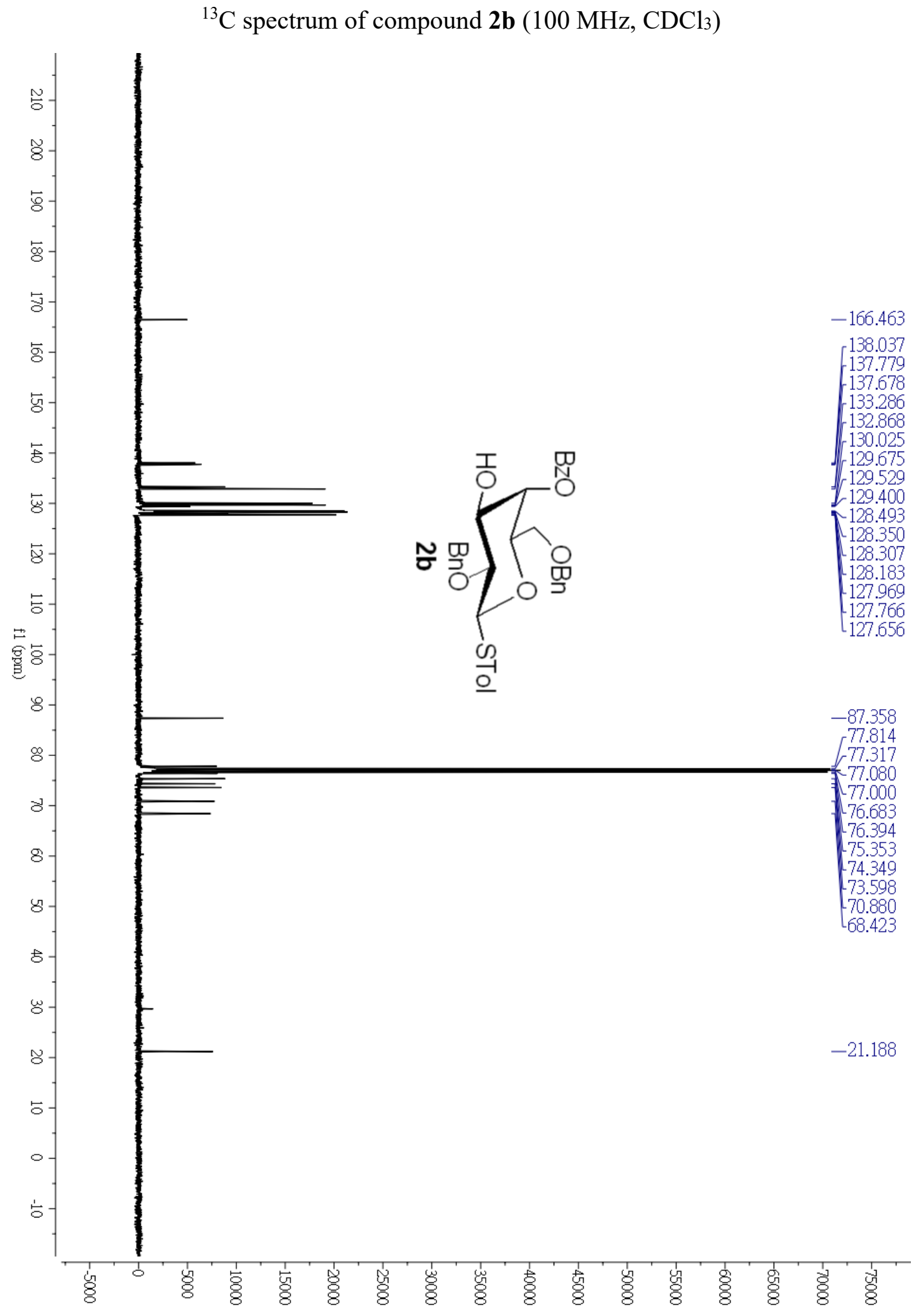


${ }^{1} \mathrm{H}$ spectrum of compound $2 \mathrm{c}\left(400 \mathrm{MHz}, \mathrm{CDCl}_{3}\right)$

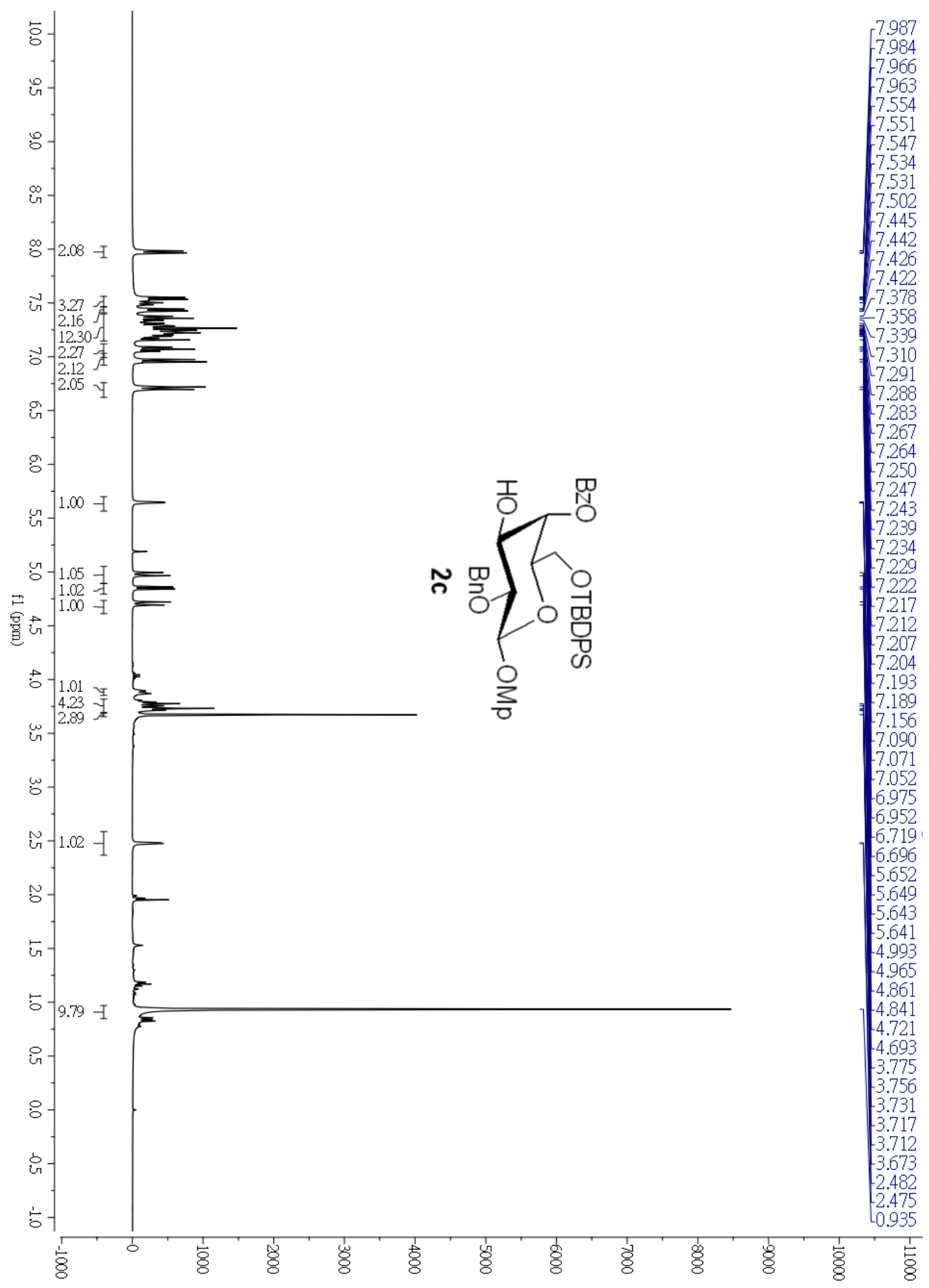


${ }^{1} \mathrm{H}-{ }^{1} \mathrm{H}$ COSY of compound $\mathbf{2 c}$




HSQC of compound 2c

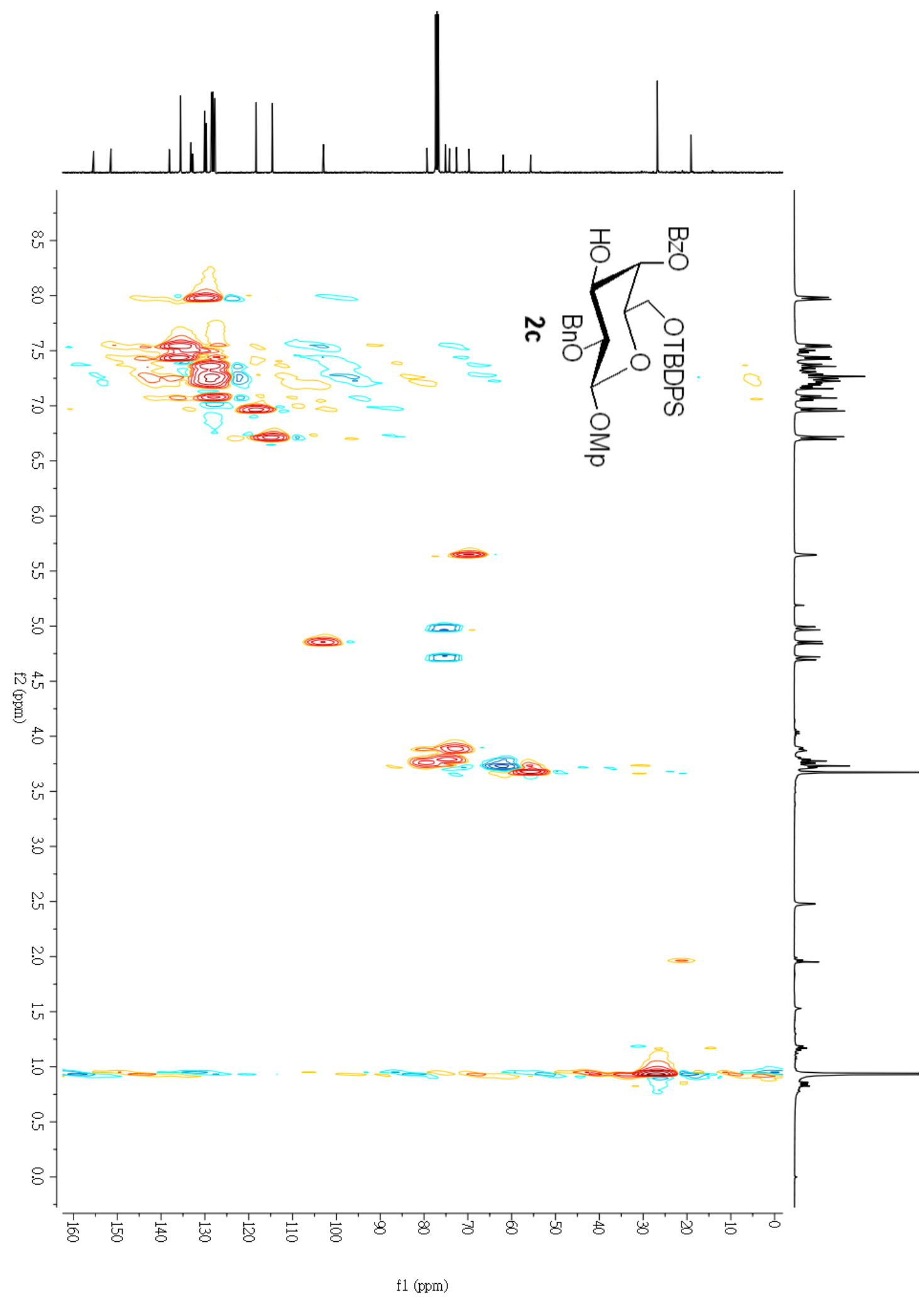


${ }^{13} \mathrm{C}$ spectrum of compound $2 \mathrm{c}\left(100 \mathrm{MHz}, \mathrm{CDCl}_{3}\right)$

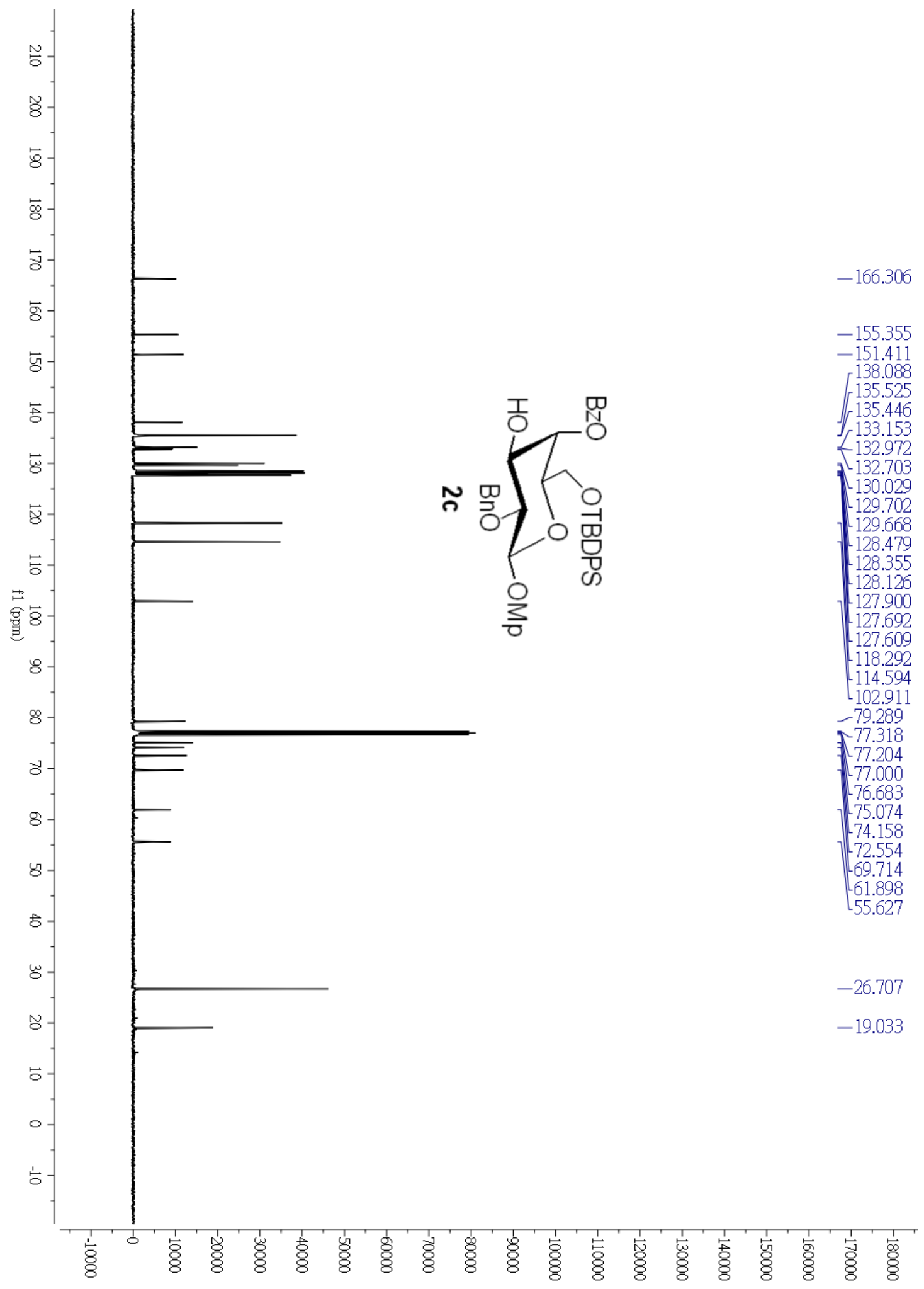


${ }^{1} \mathrm{H}$ spectrum of compound $2 \mathbf{d}\left(400 \mathrm{MHz}, \mathrm{CDCl}_{3}\right)$

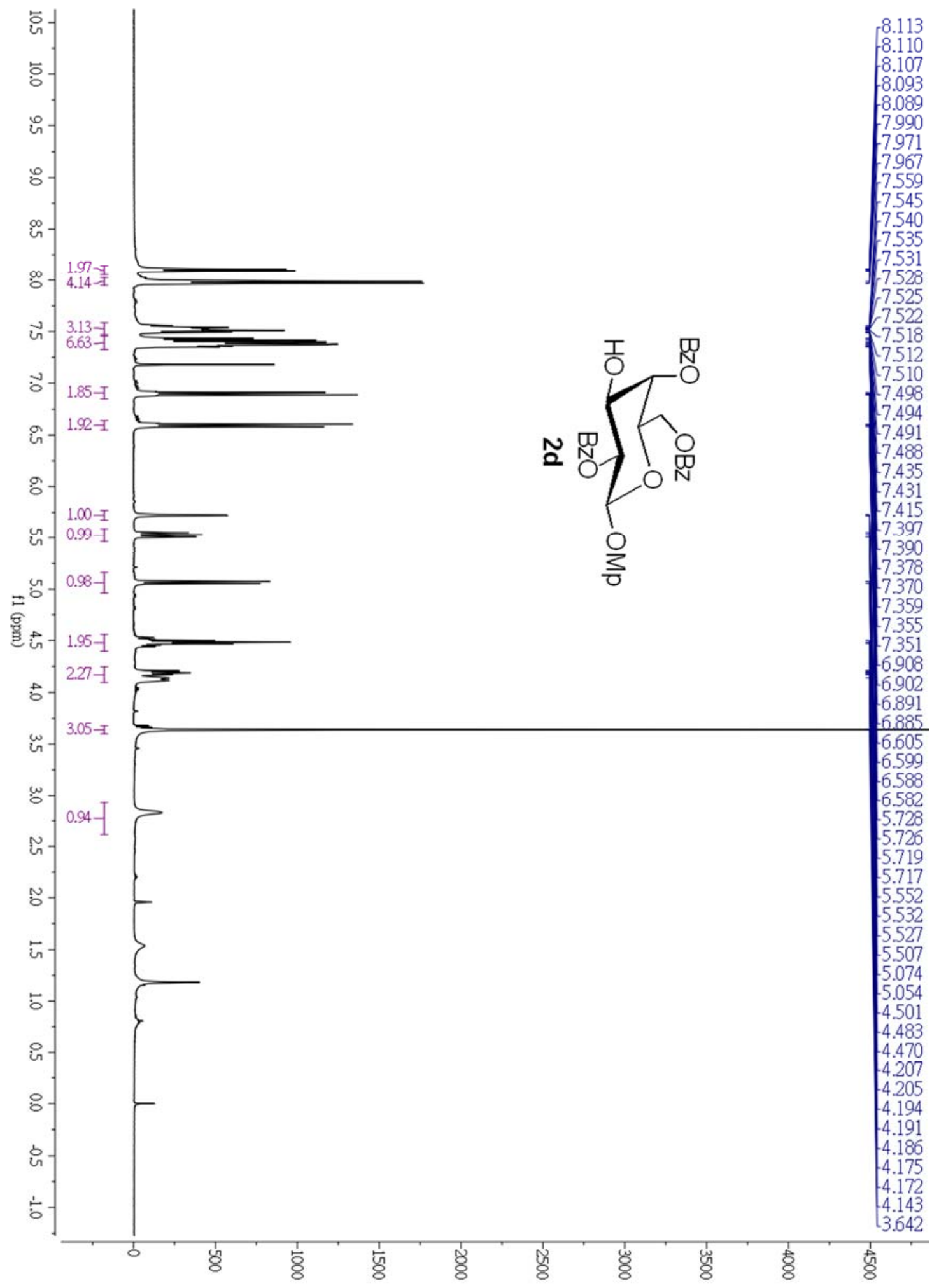


${ }^{1} \mathrm{H}$ spectrum of compound $2 \mathrm{e}\left(400 \mathrm{MHz}, \mathrm{CDCl}_{3}\right)$

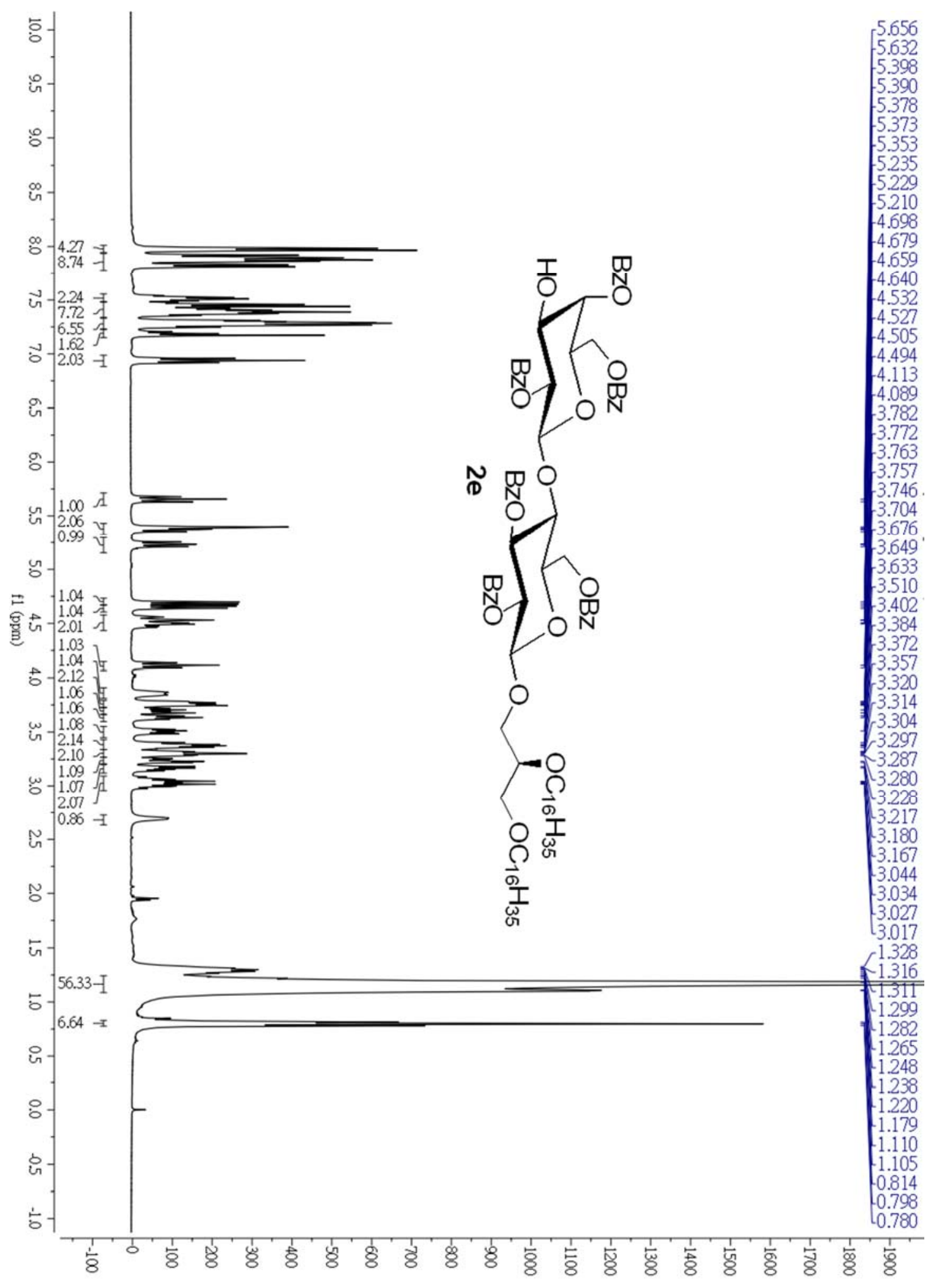




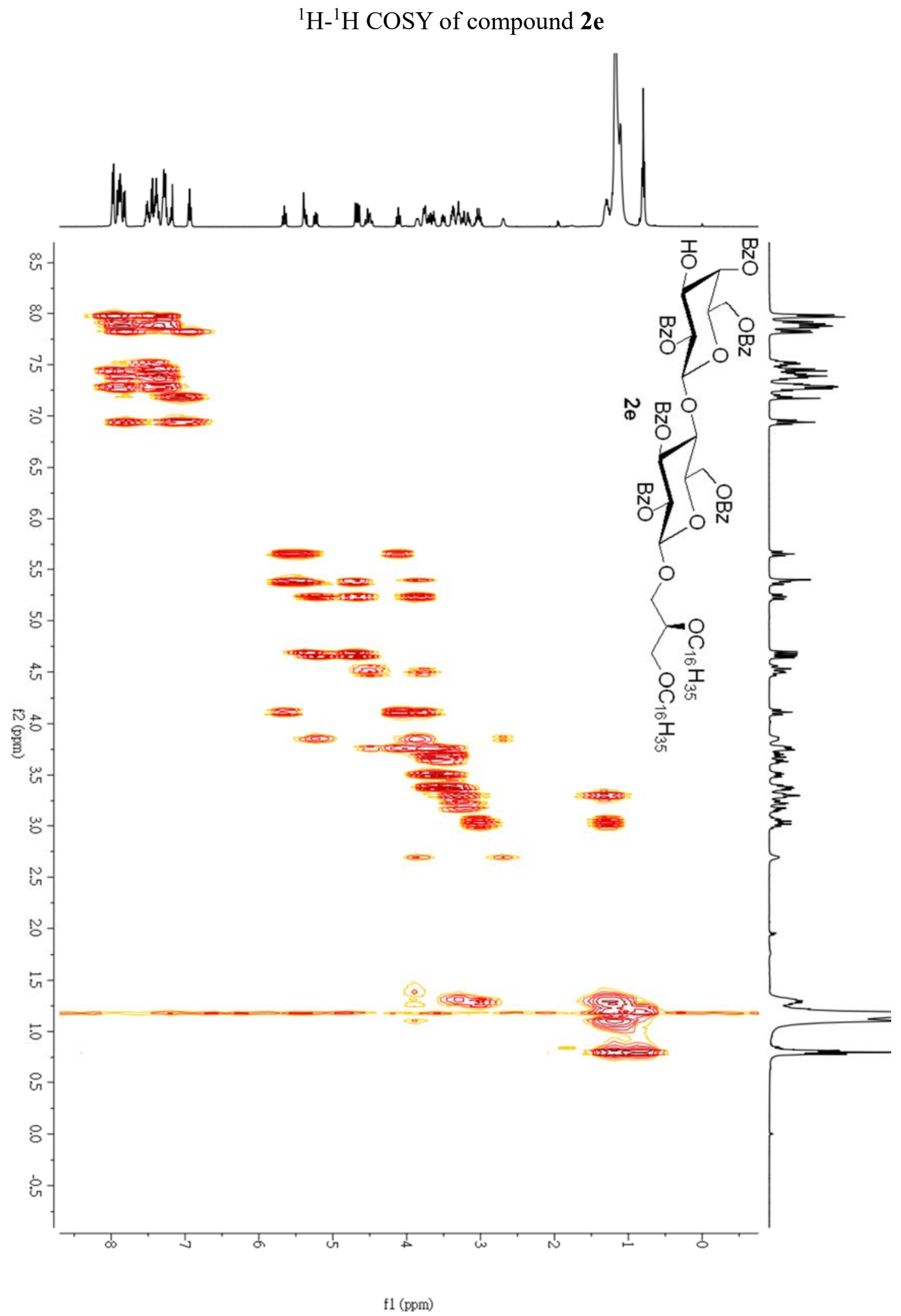

S45 


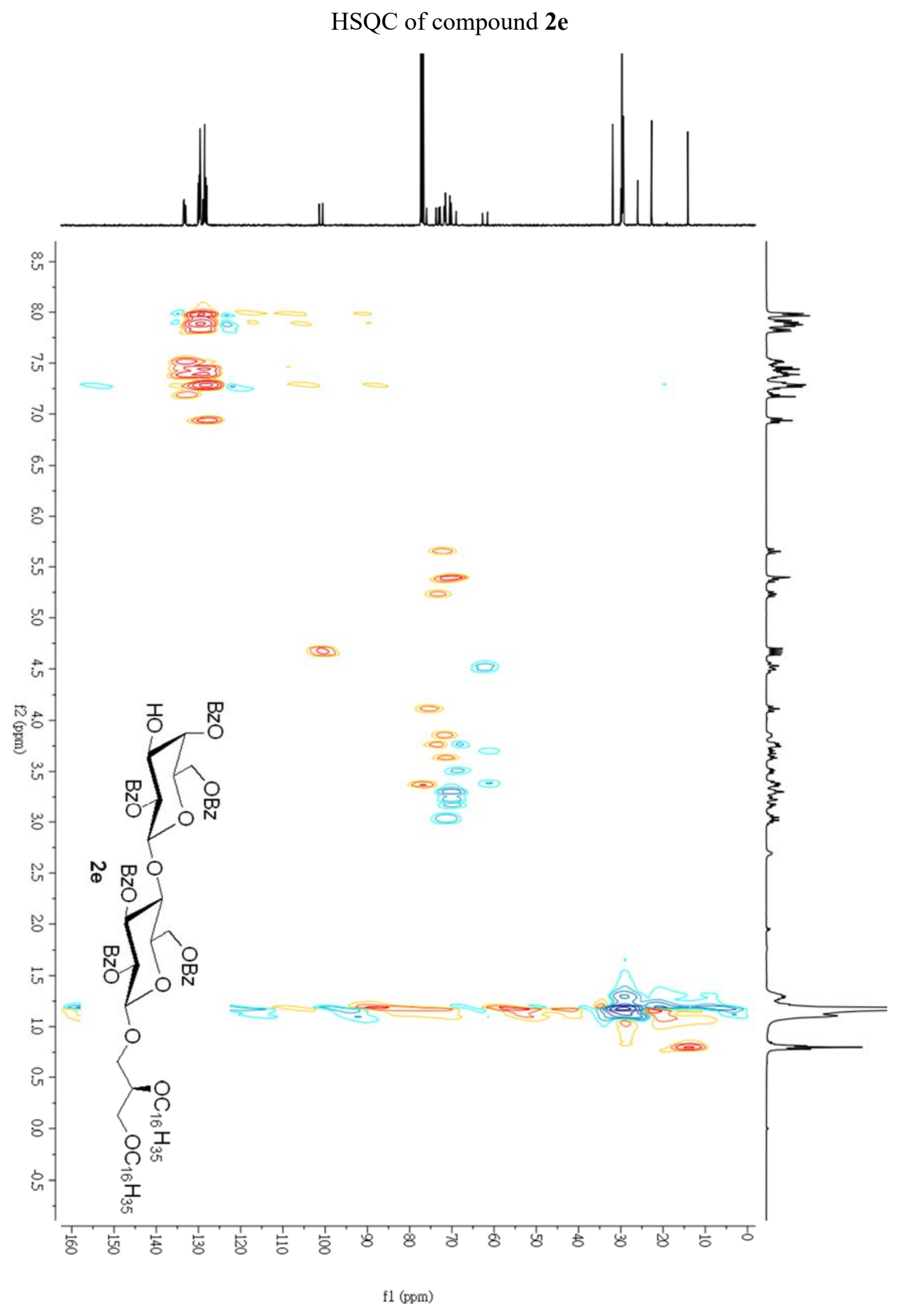


${ }^{13} \mathrm{C}$ spectrum of compound $2 \mathrm{e}\left(100 \mathrm{MHz}, \mathrm{CDCl}_{3}\right)$

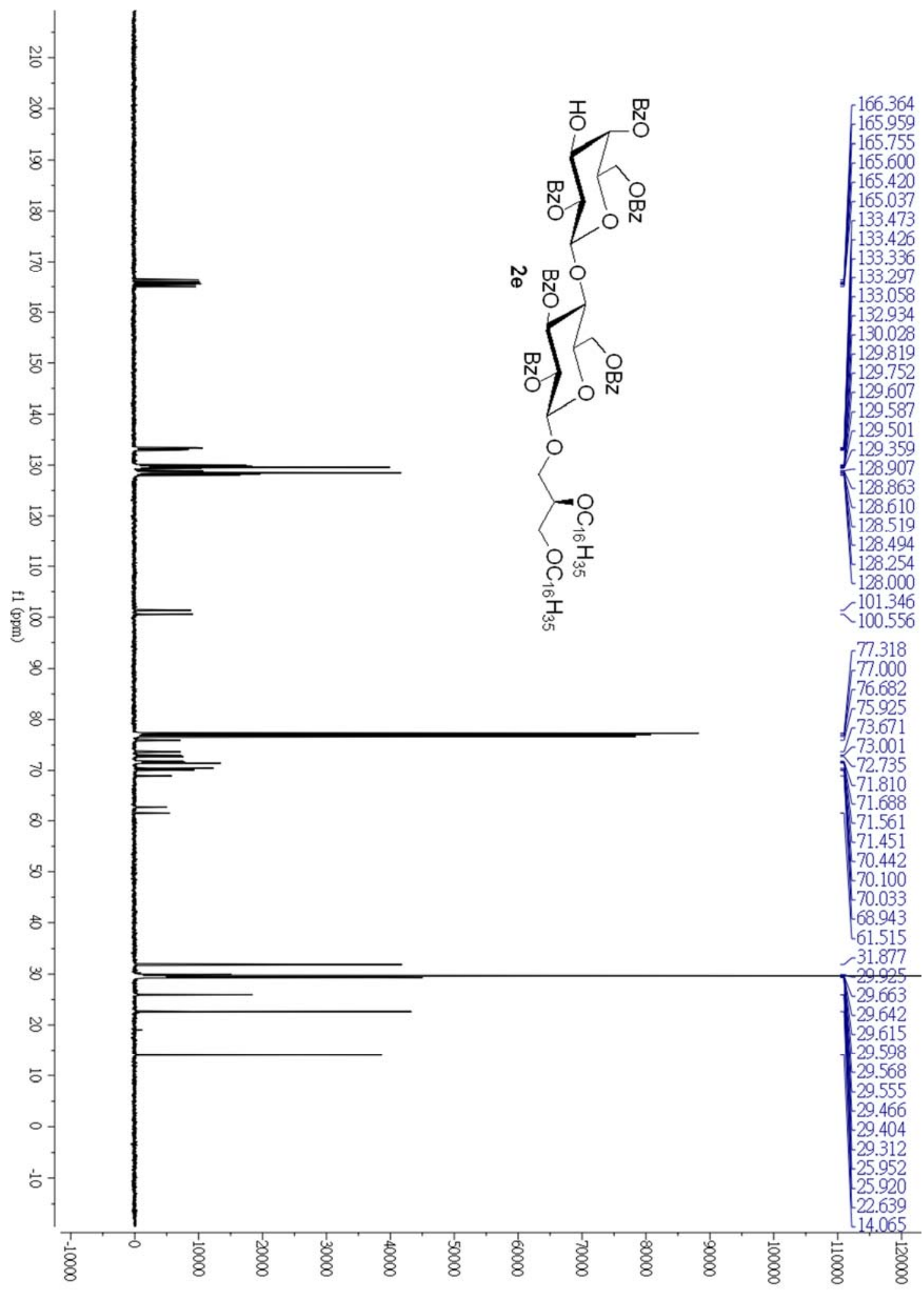


${ }^{1} \mathrm{H}$ spectrum of compound $2 \mathbf{f}\left(400 \mathrm{MHz}, \mathrm{CDCl}_{3}\right)$

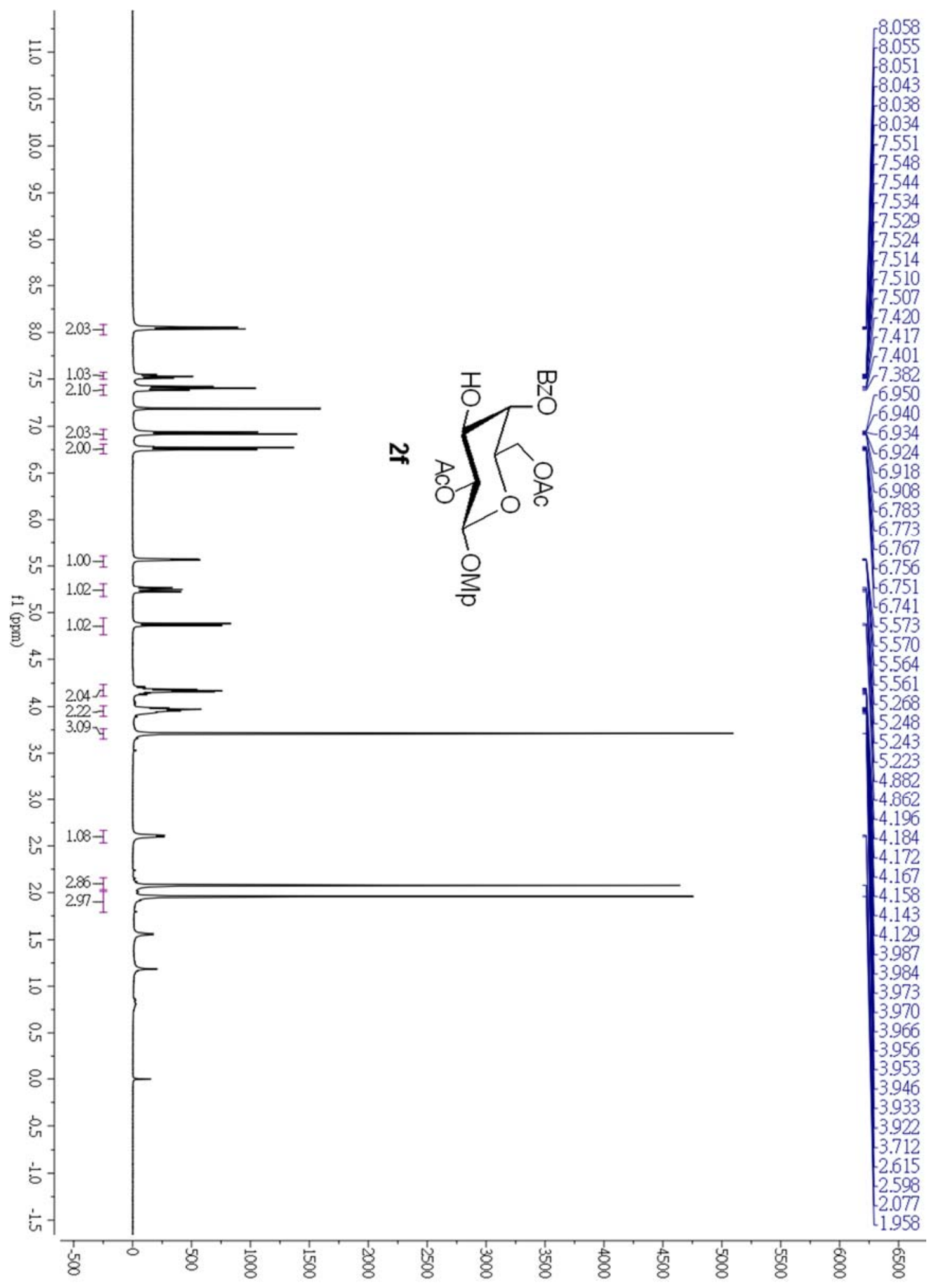


${ }^{1} \mathrm{H}-{ }^{1} \mathrm{H}$ COSY of compound $\mathbf{2 f}$

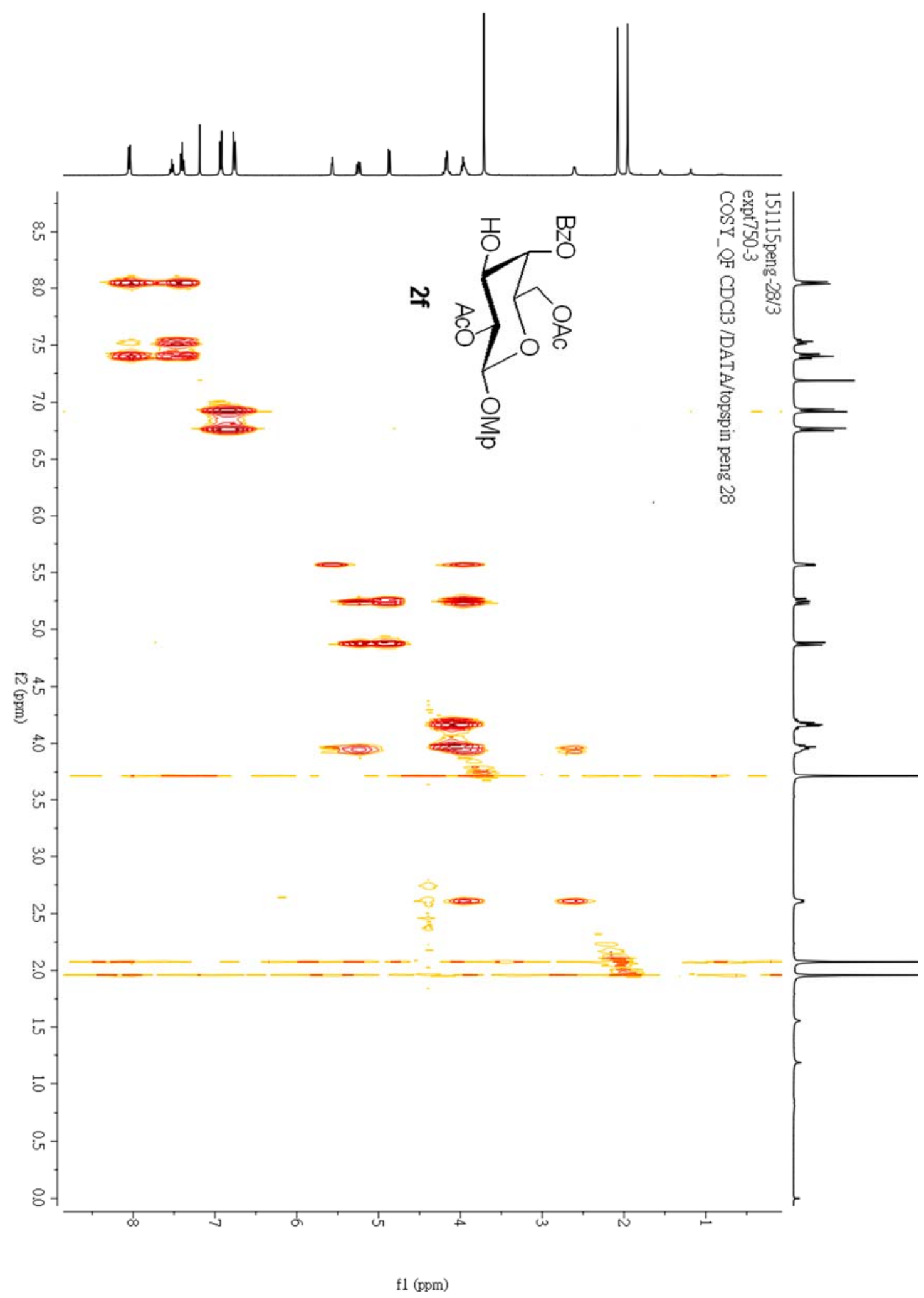




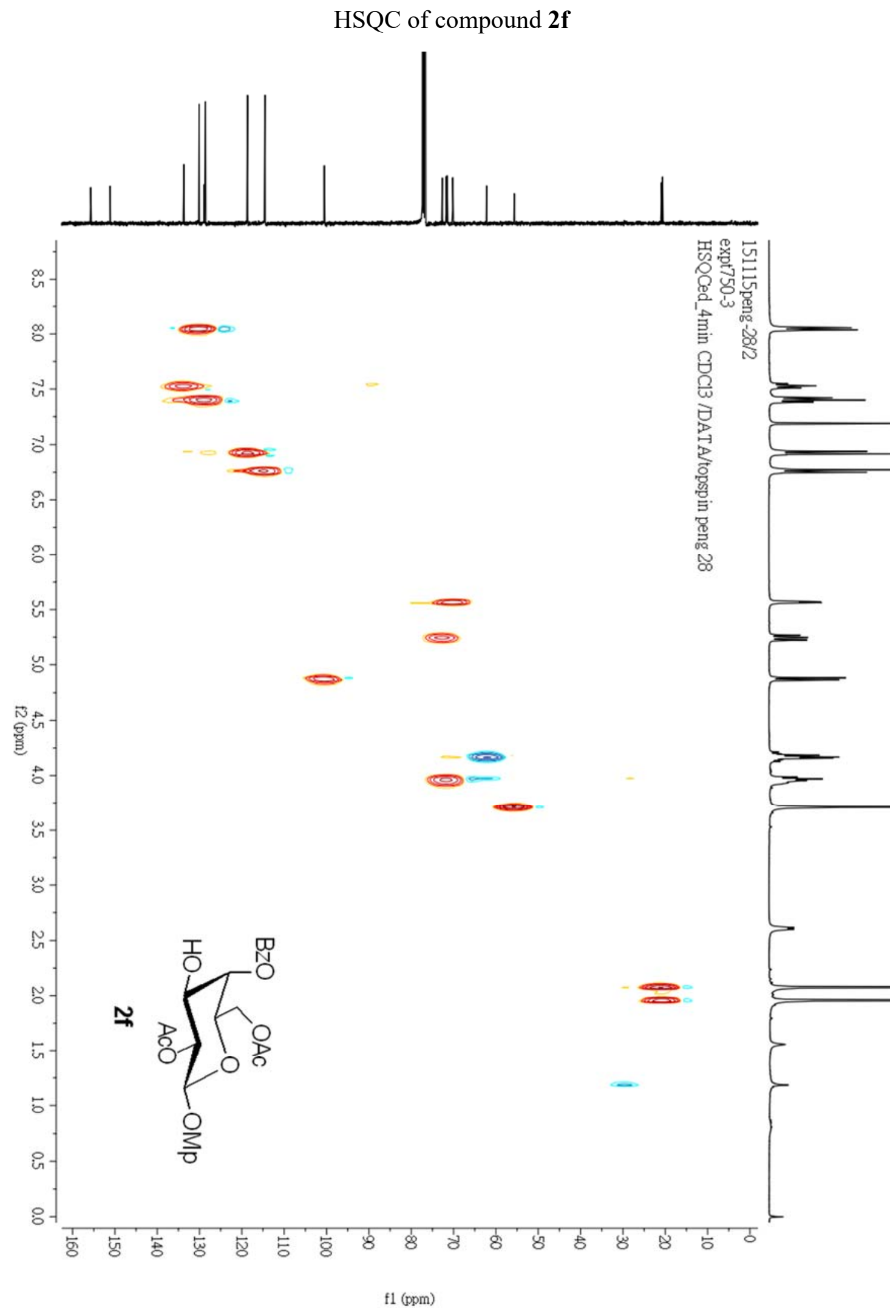


${ }^{13} \mathrm{C}$ spectrum of compound $2 \mathbf{f}\left(100 \mathrm{MHz}, \mathrm{CDCl}_{3}\right)$

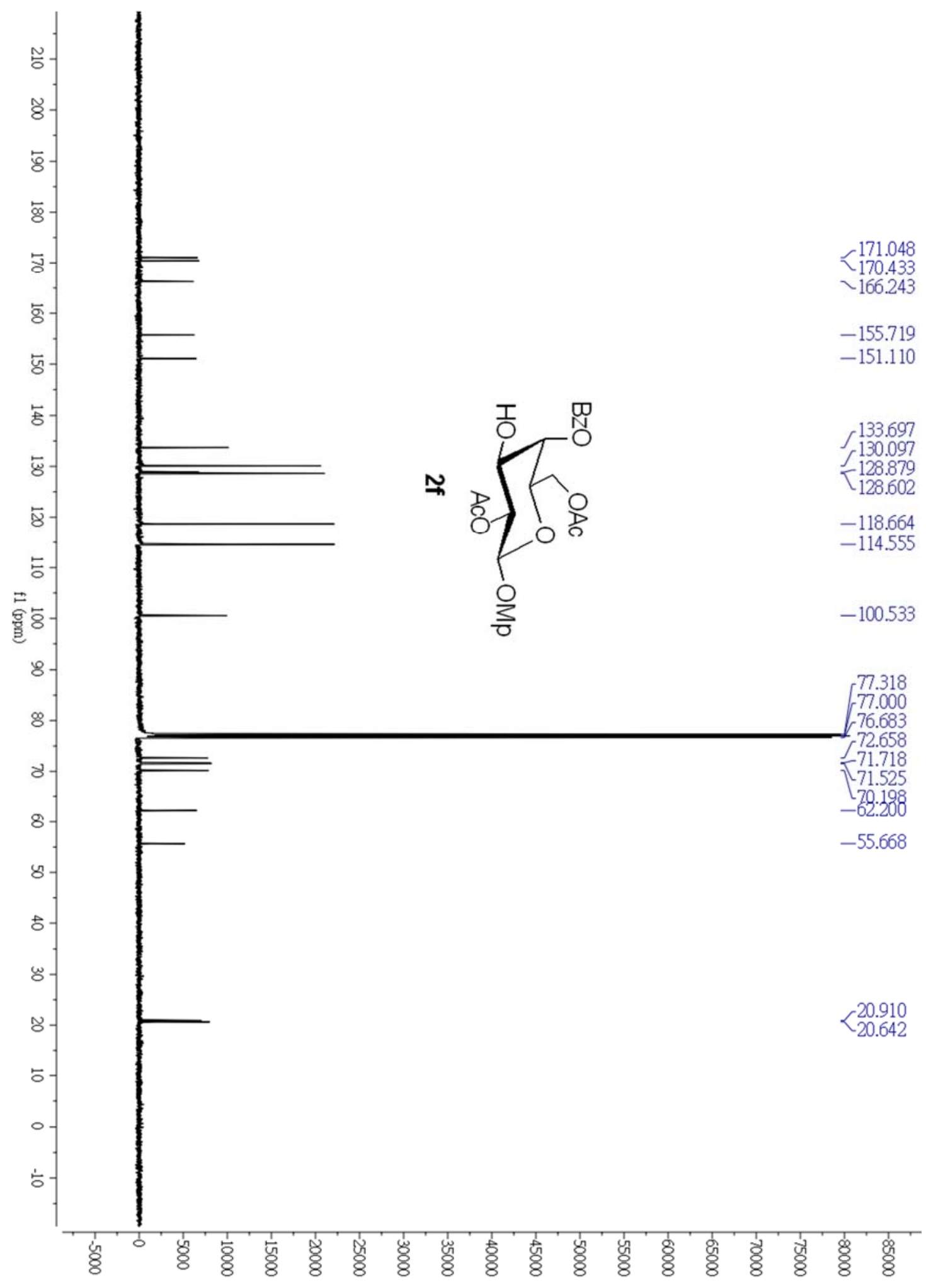


${ }^{1} \mathrm{H}$ spectrum of compound $\mathbf{2 g}\left(400 \mathrm{MHz}, \mathrm{CDCl}_{3}\right)$

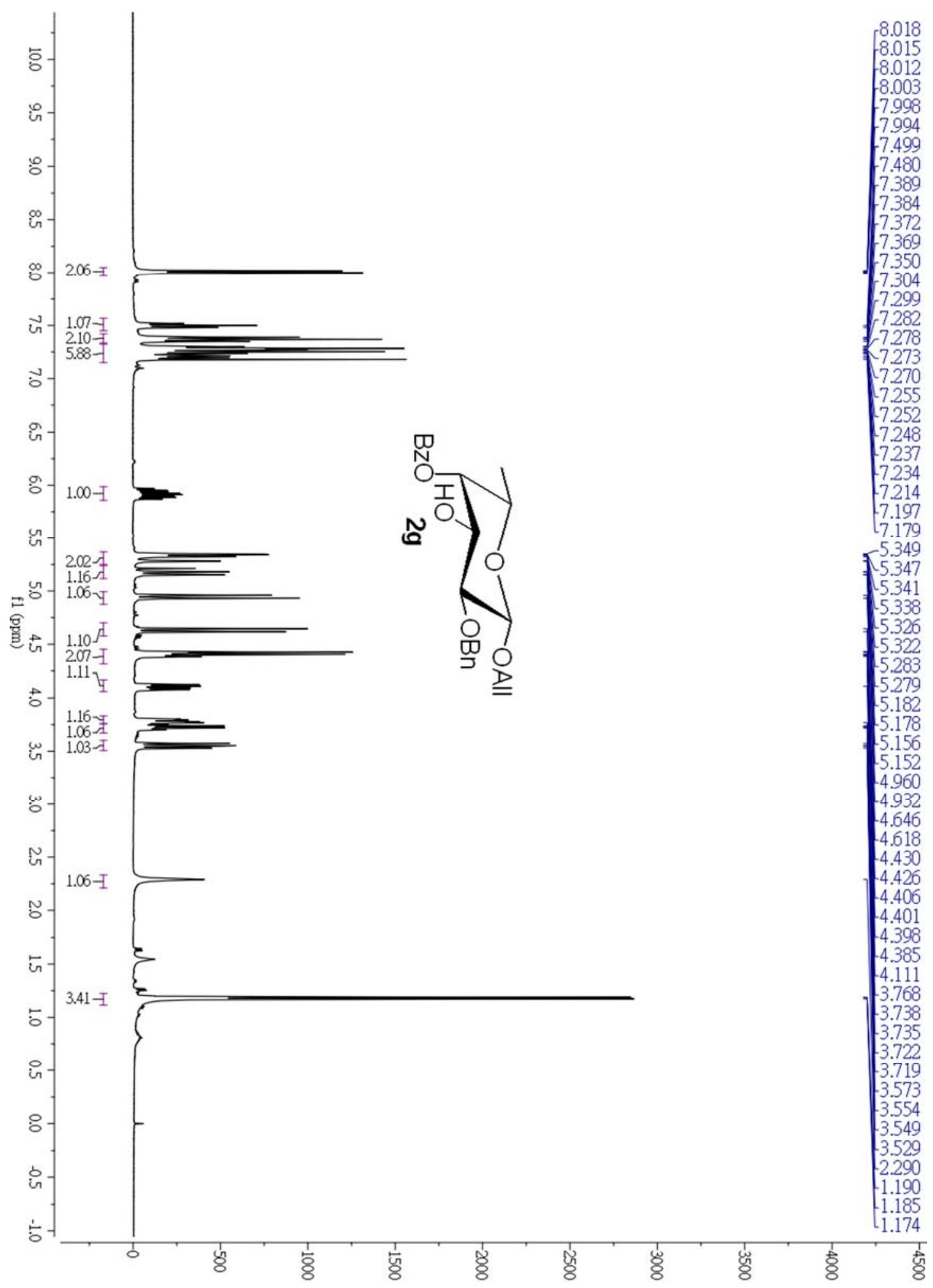


${ }^{1} \mathrm{H}-{ }^{1} \mathrm{H}$ COSY of compound $\mathbf{2 g}$

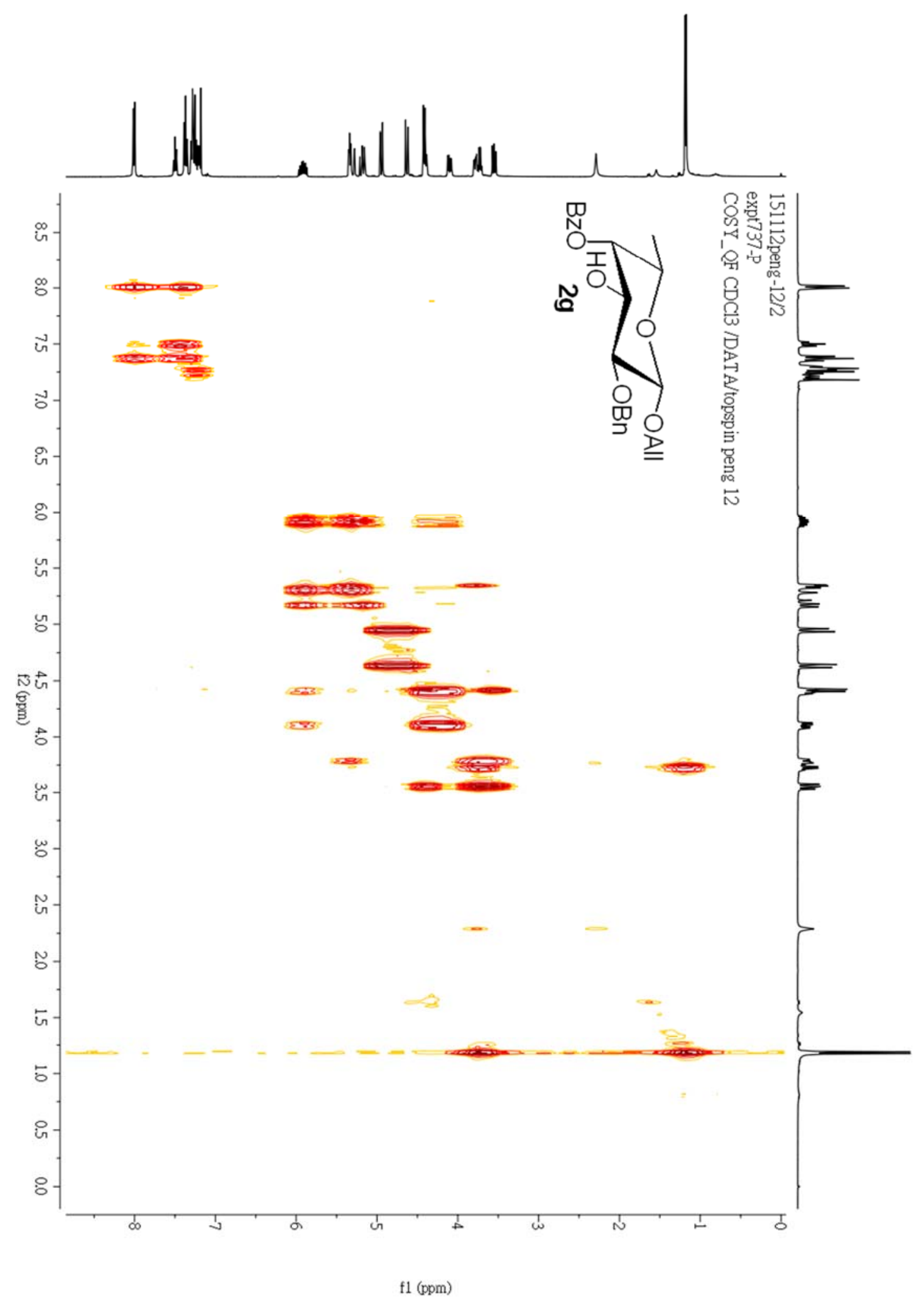




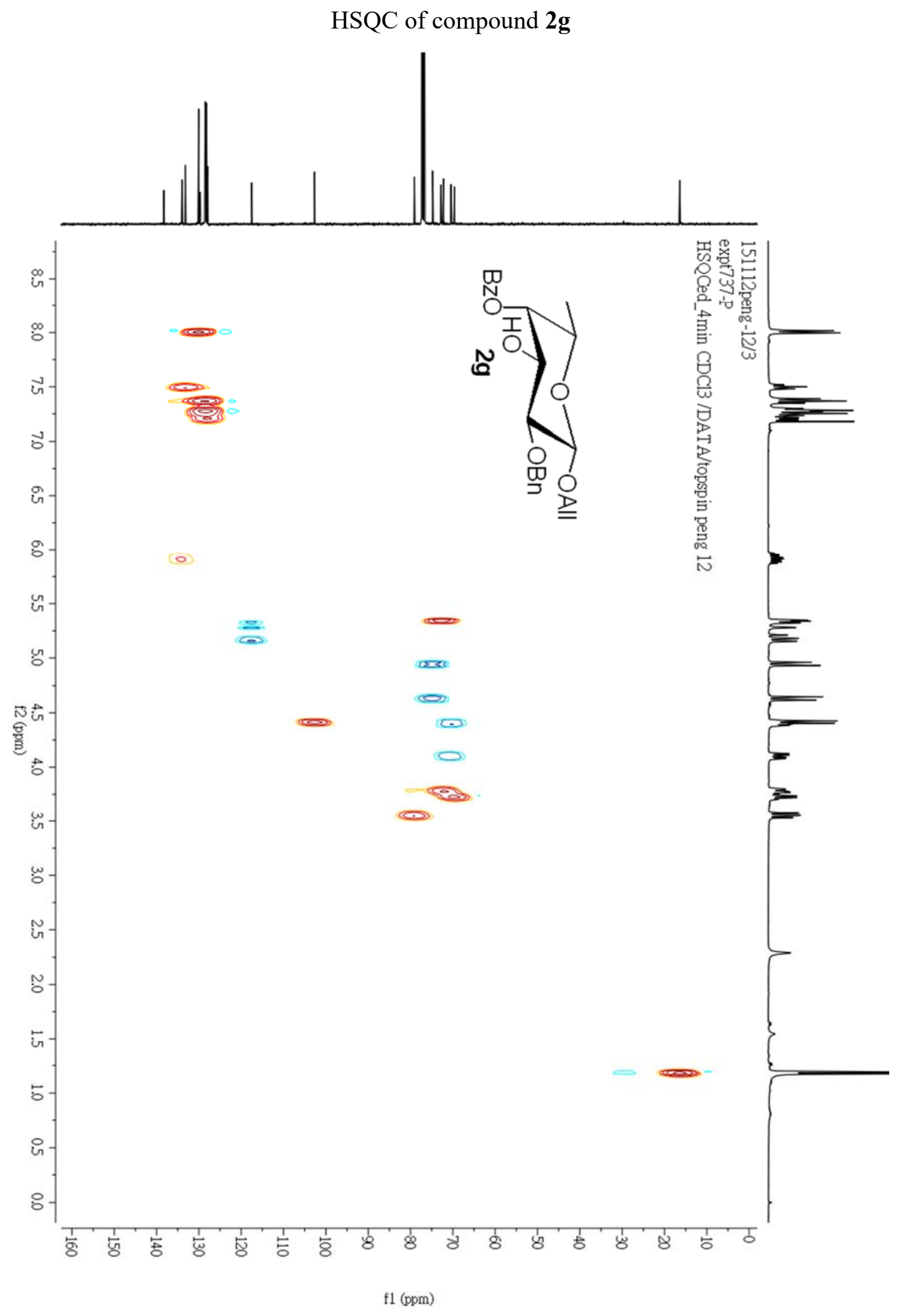







${ }^{1} \mathrm{H}$ spectrum of compound $\mathbf{2 h}\left(400 \mathrm{MHz}, \mathrm{CDCl}_{3}\right)$

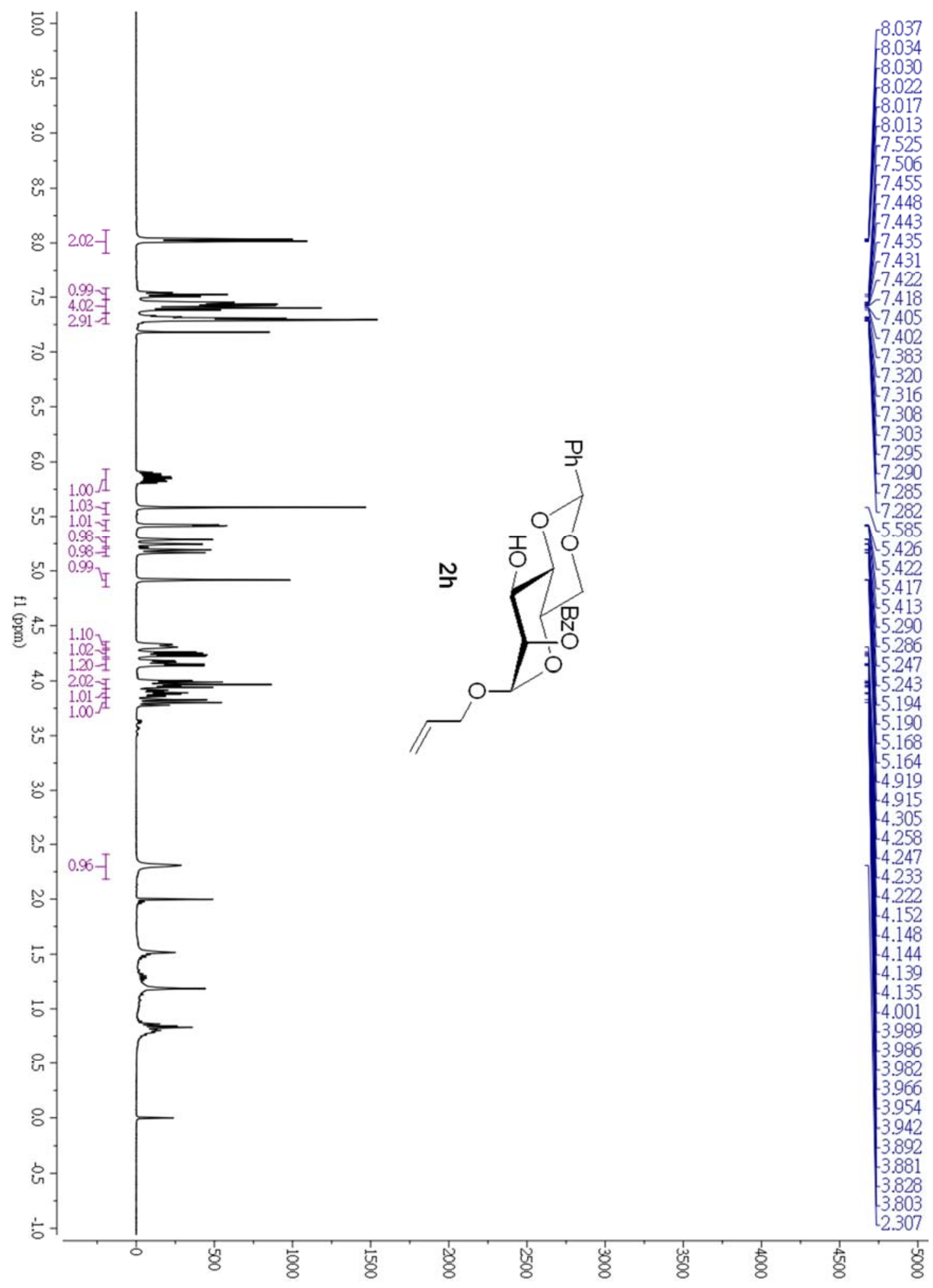


${ }^{1} \mathrm{H}-{ }^{1} \mathrm{H}$ COSY of compound $\mathbf{2 h}$

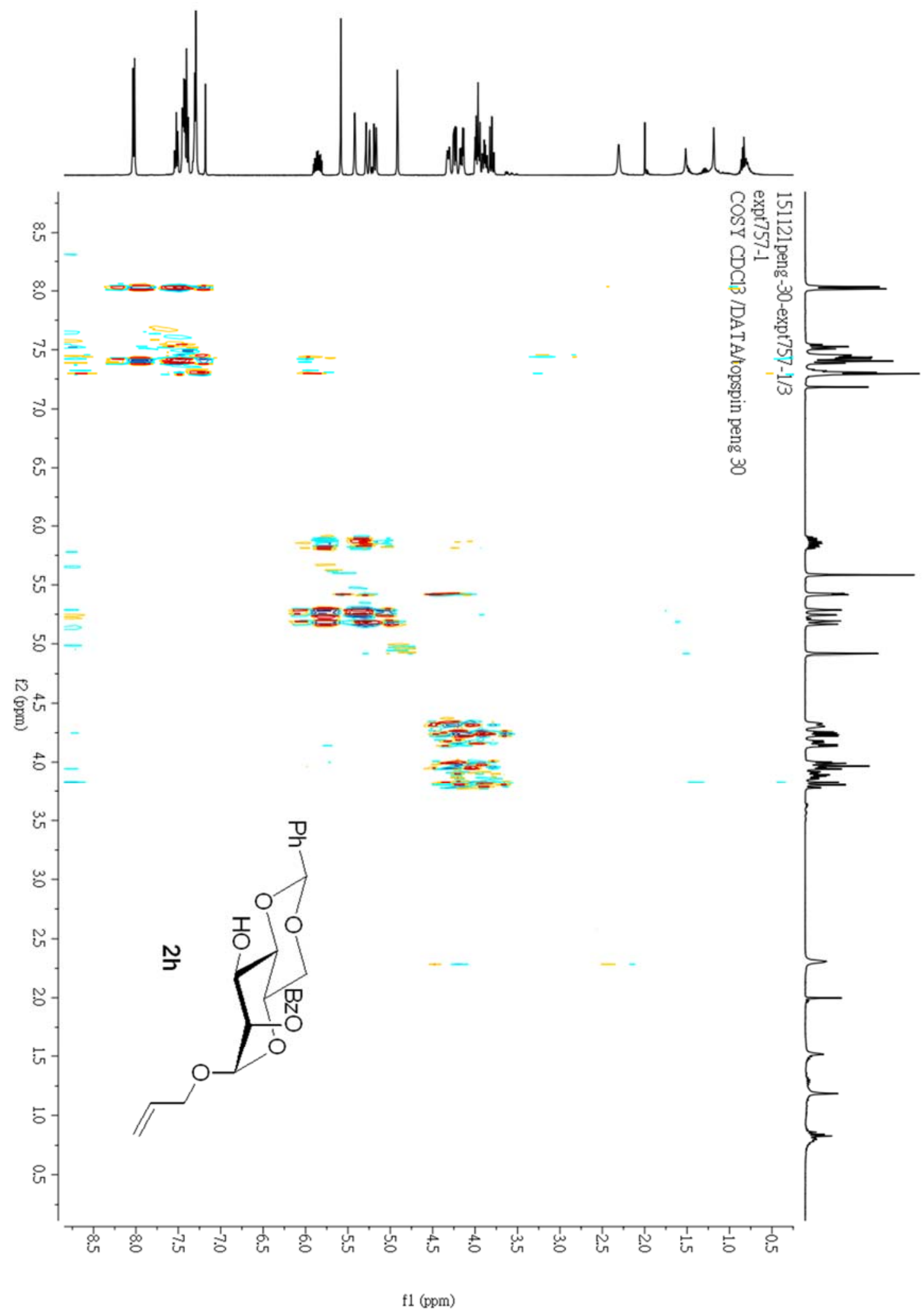


HSQC of compound $\mathbf{2 h}$

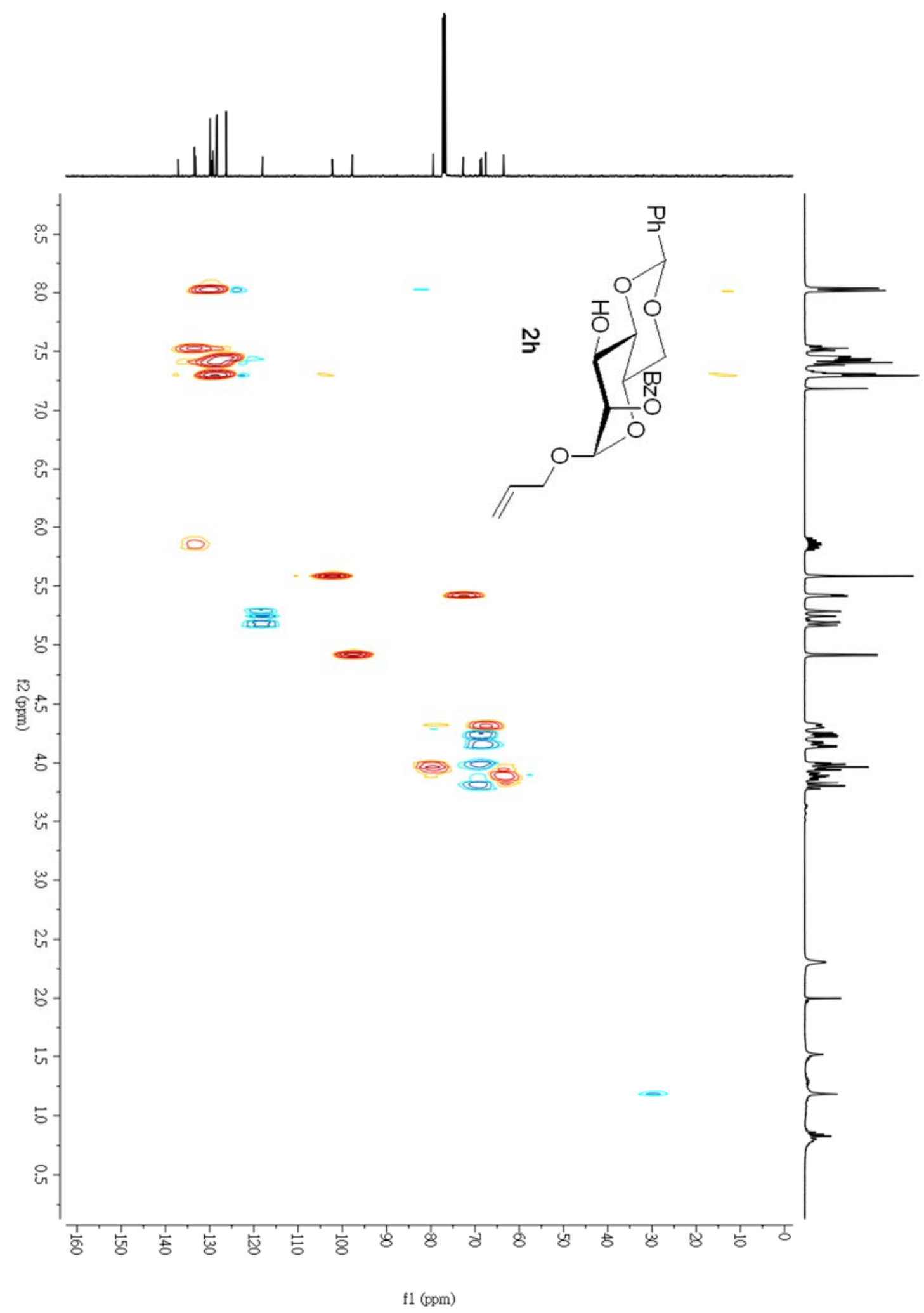




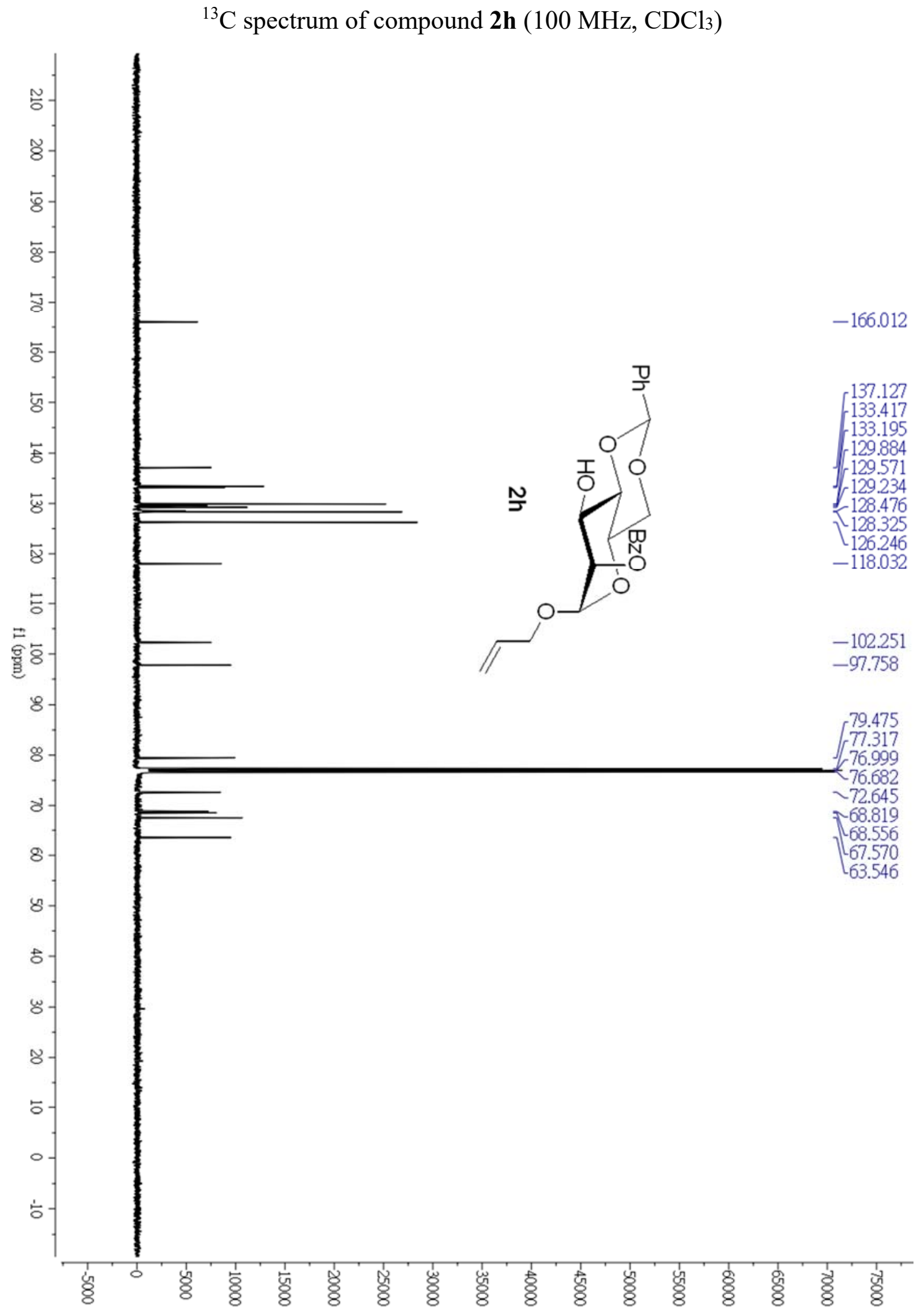


${ }^{1} \mathrm{H}$ spectrum of compound $2 \mathbf{i}\left(400 \mathrm{MHz}, \mathrm{CDCl}_{3}\right)$

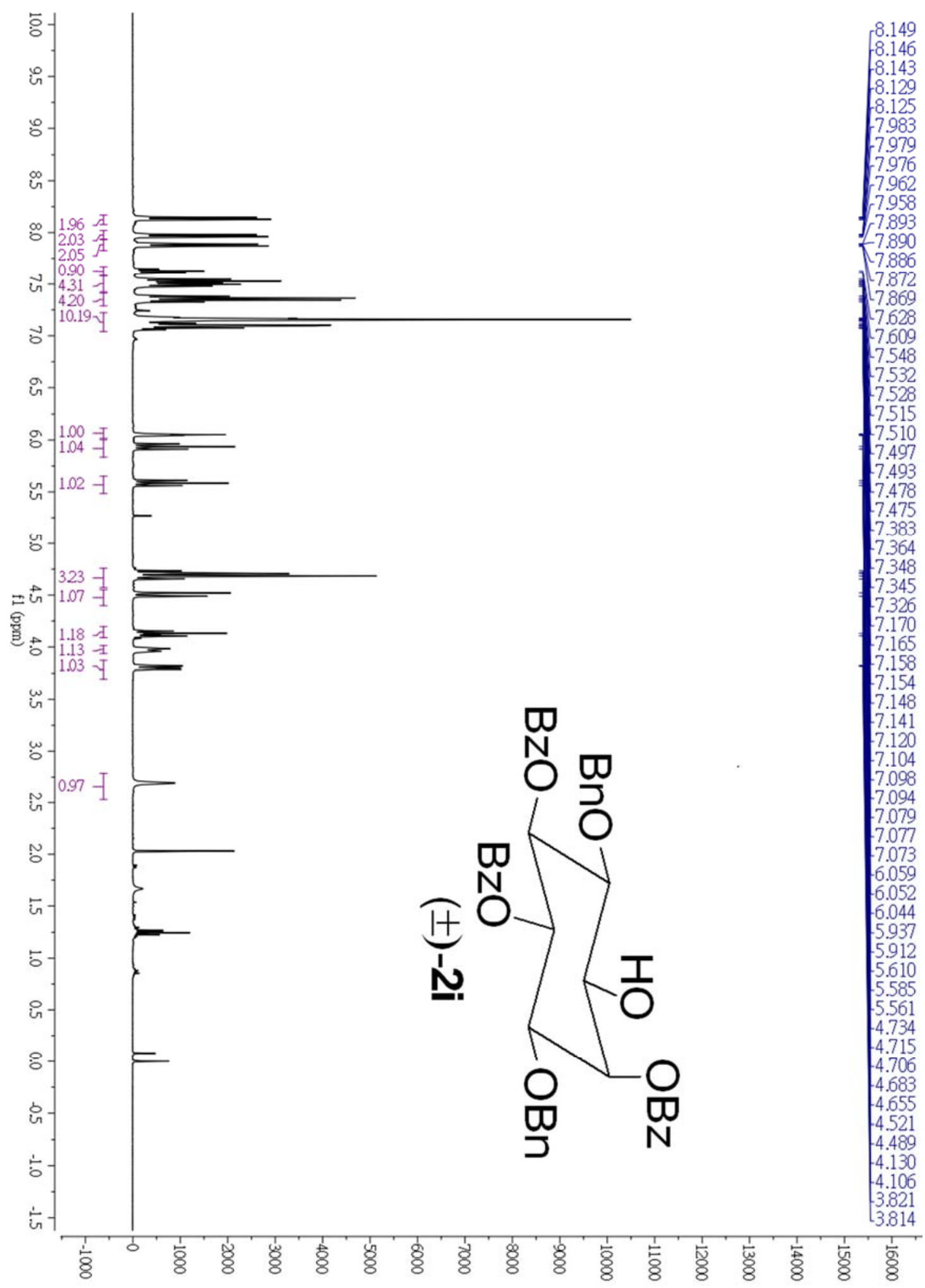


${ }^{1} \mathrm{H}-{ }^{1} \mathrm{H}$ COSY of compound $\mathbf{2 i}$

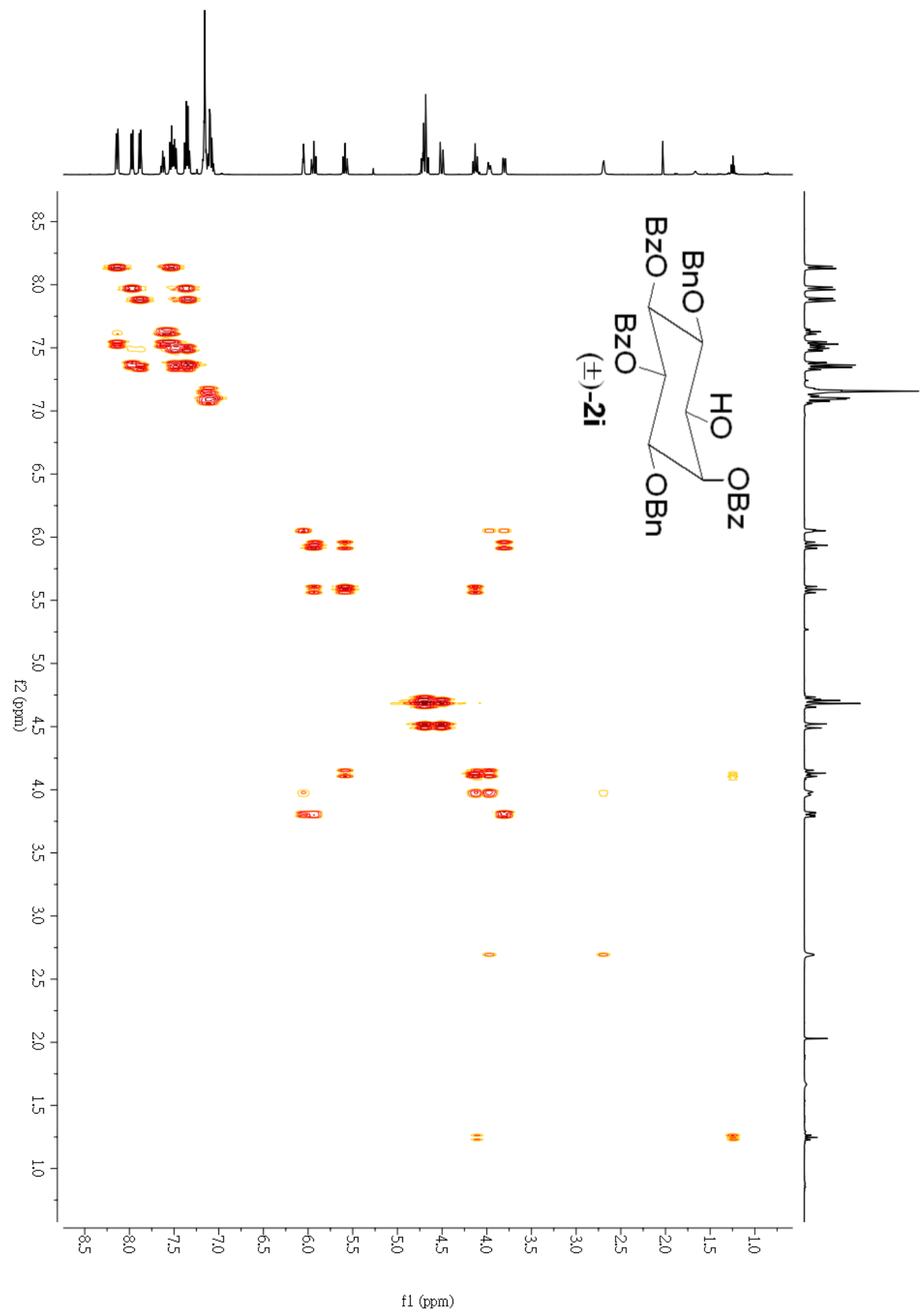


HSQC of compound $\mathbf{2 i}$

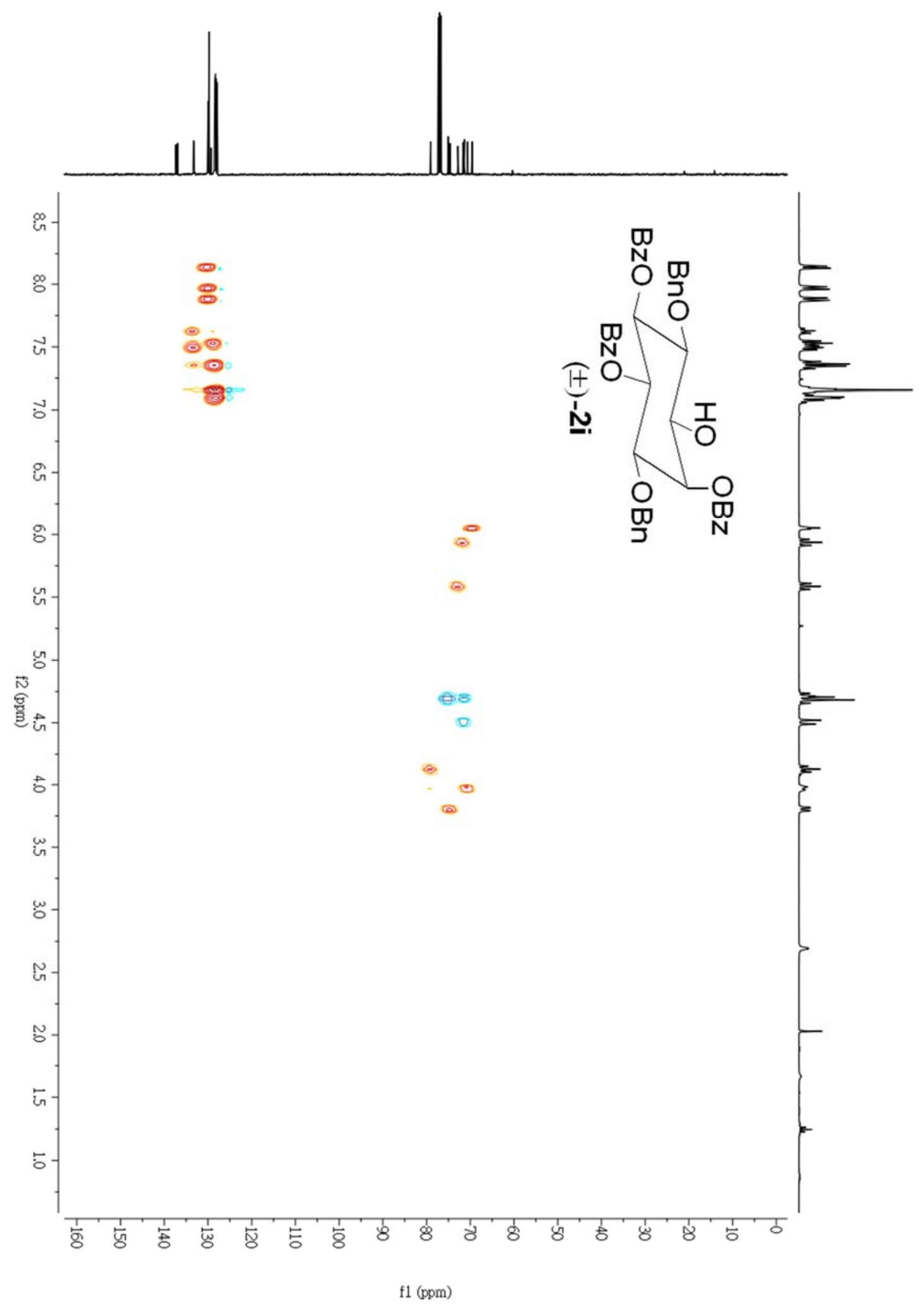


${ }^{13} \mathrm{C}$ spectrum of compound $2 \mathbf{i}\left(100 \mathrm{MHz}, \mathrm{CDCl}_{3}\right)$

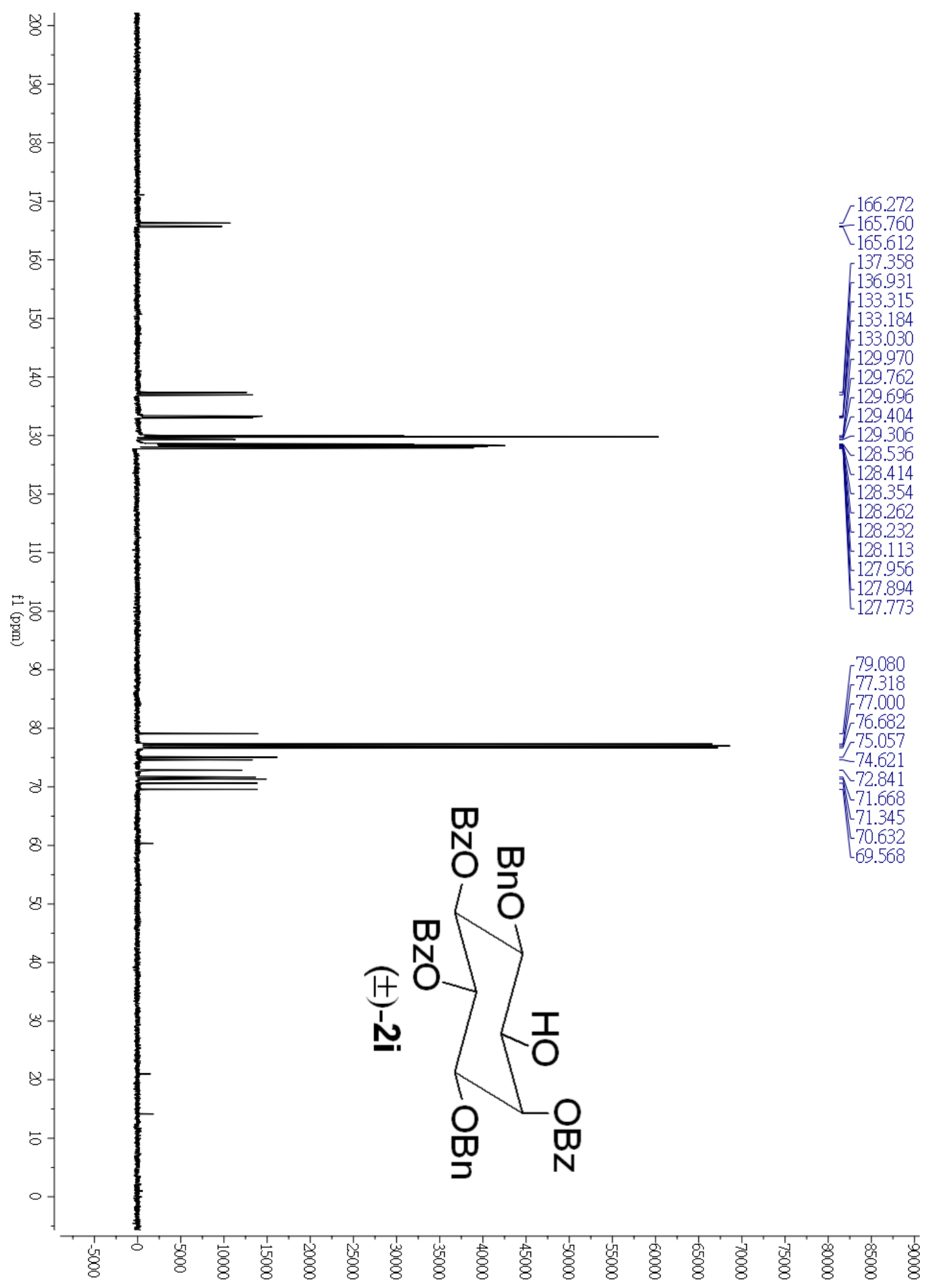


${ }^{1} \mathrm{H}$ spectrum of compound $\mathbf{6 a}\left(400 \mathrm{MHz}, \mathrm{CDCl}_{3}\right)$

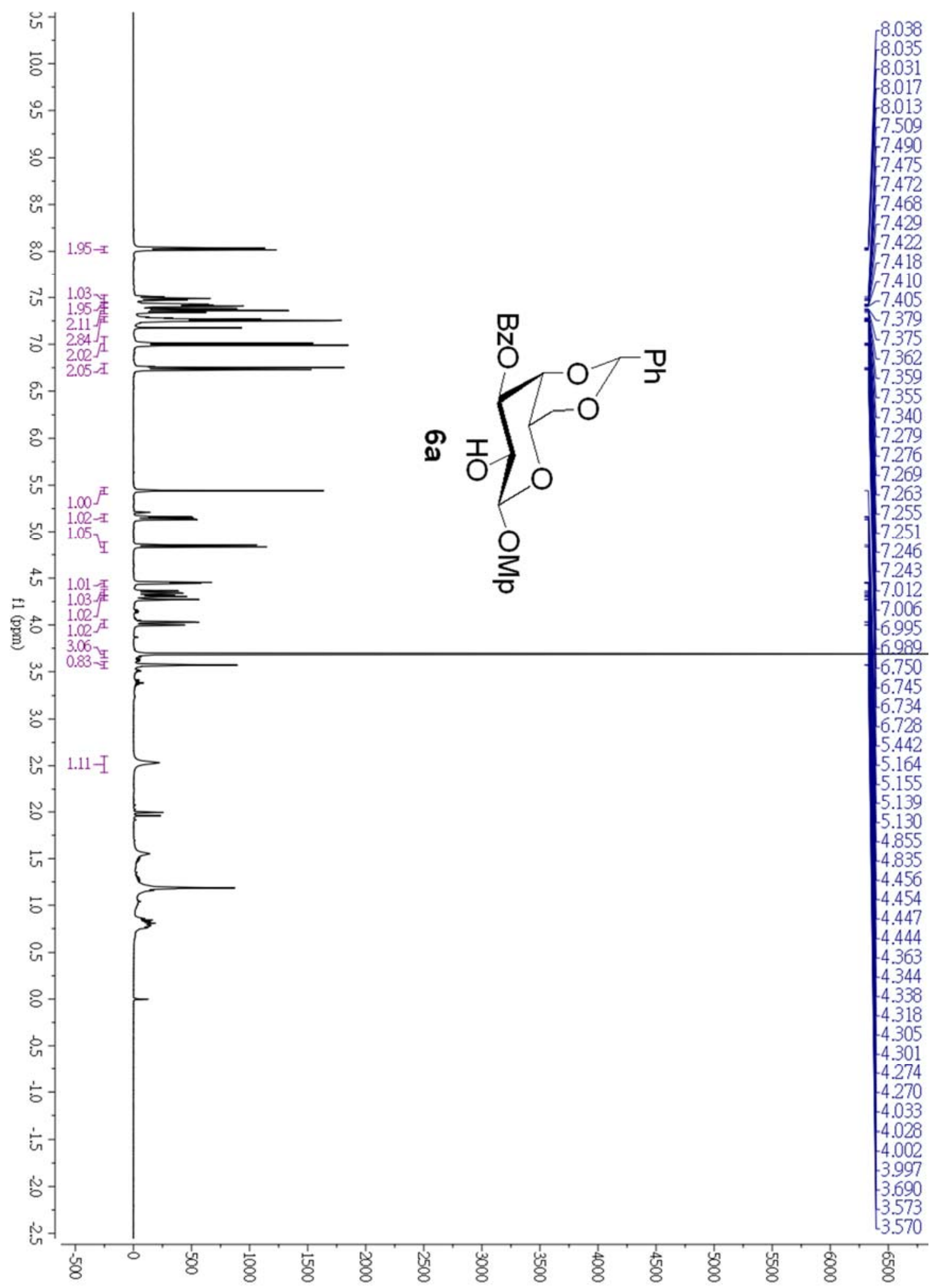


${ }^{1} \mathrm{H}$ spectrum of compound $\mathbf{8 b}\left(400 \mathrm{MHz}, \mathrm{CDCl}_{3}\right)$

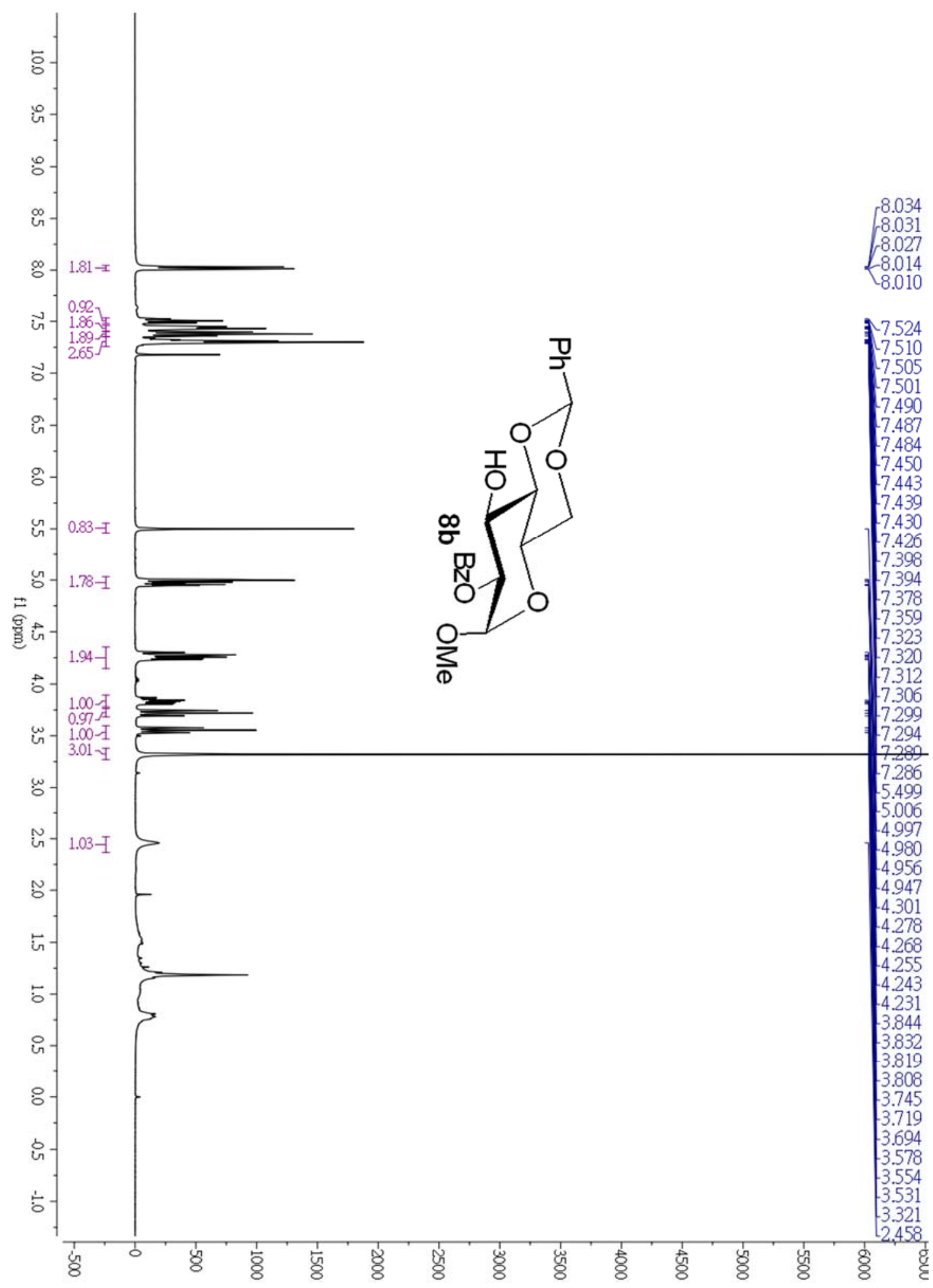


${ }^{1} \mathrm{H}$ spectrum of compound $\mathbf{1 0 a}\left(400 \mathrm{MHz}, \mathrm{CDCl}_{3}\right)$

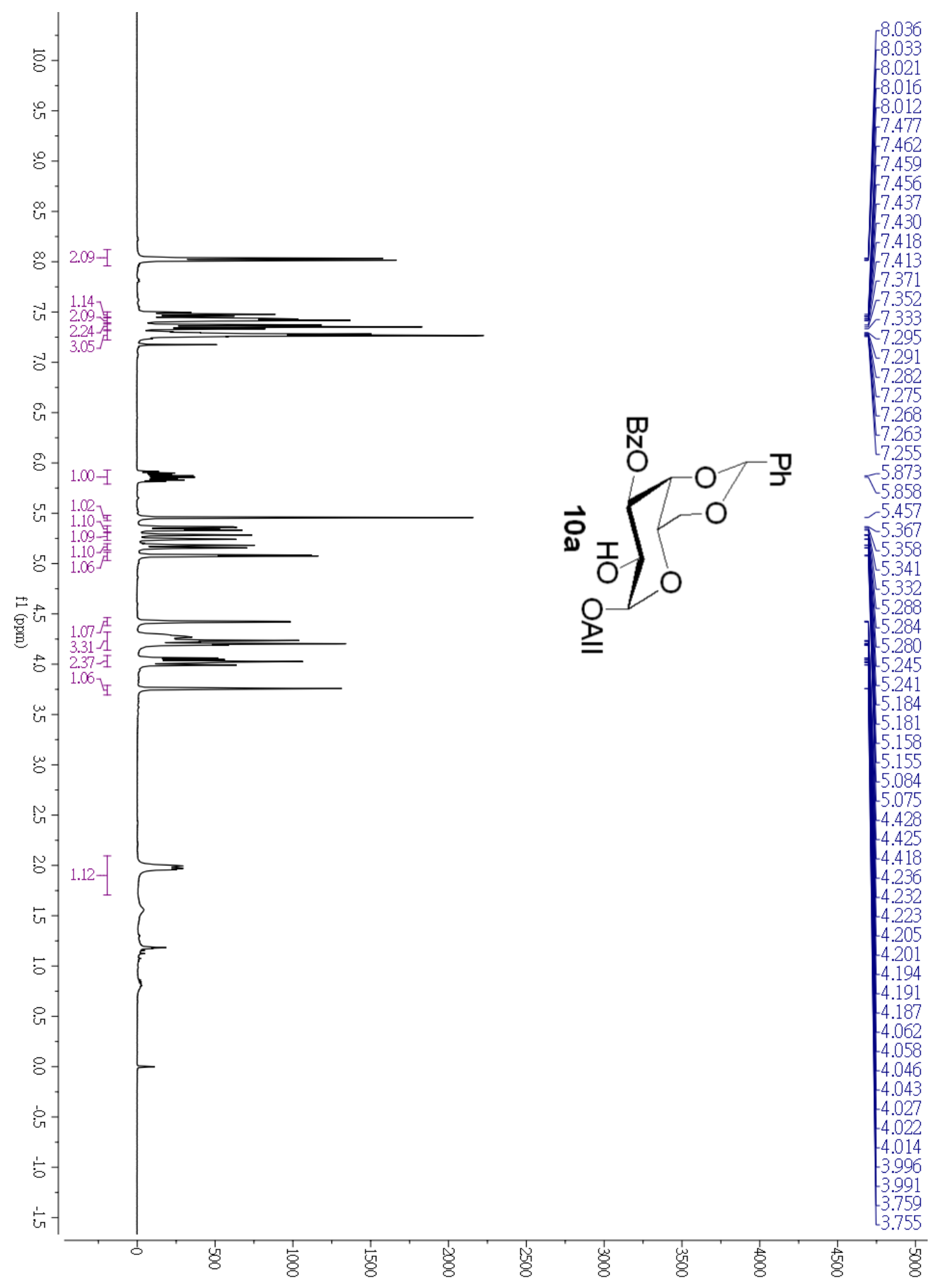


${ }^{1} \mathrm{H}$ spectrum of compound $\mathbf{1 0 b}\left(400 \mathrm{MHz}, \mathrm{CDCl}_{3}\right)$

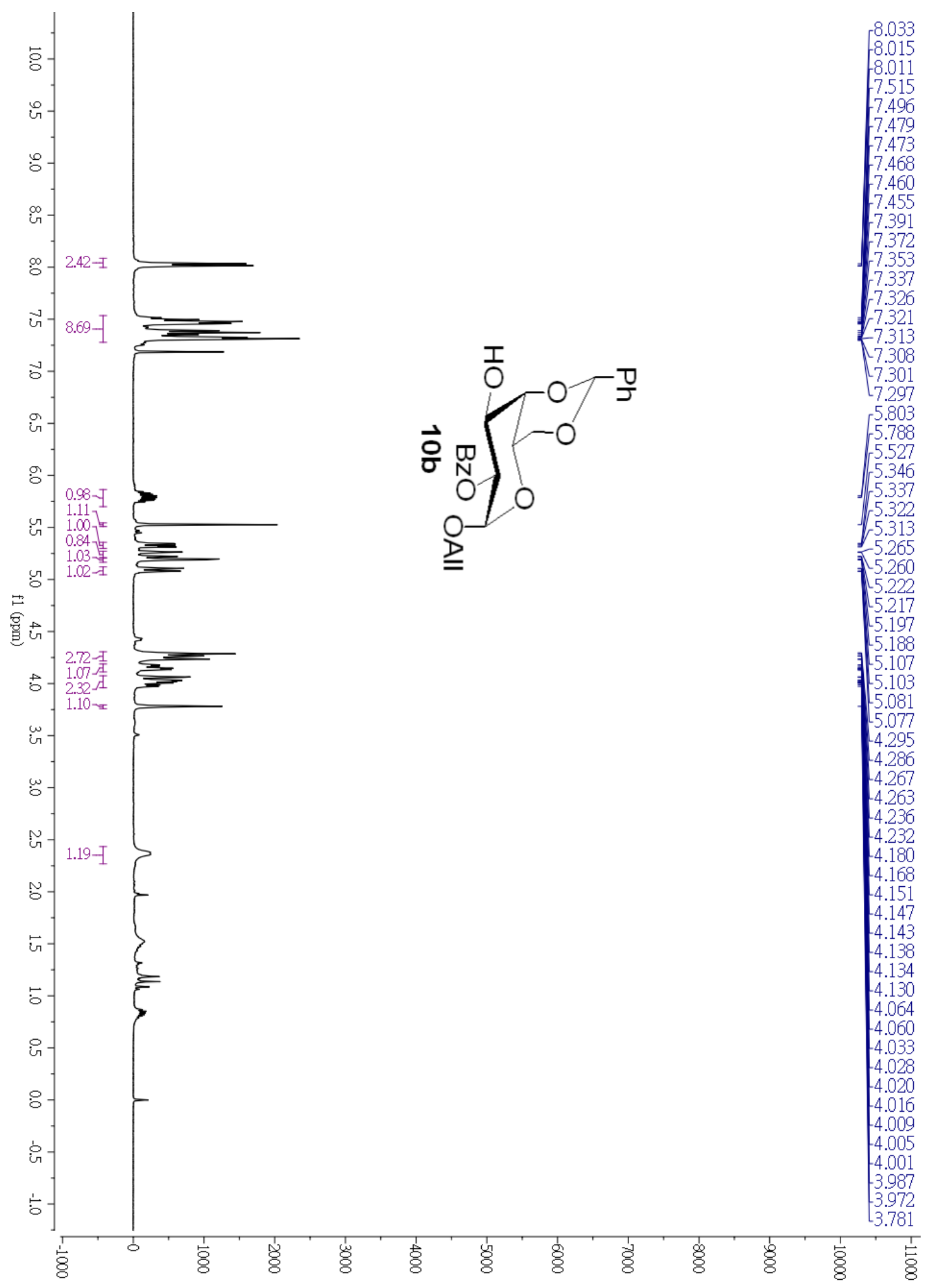


${ }^{1} \mathrm{H}$ spectrum of compound 11a $\left(400 \mathrm{MHz}, \mathrm{CDCl}_{3}\right)$

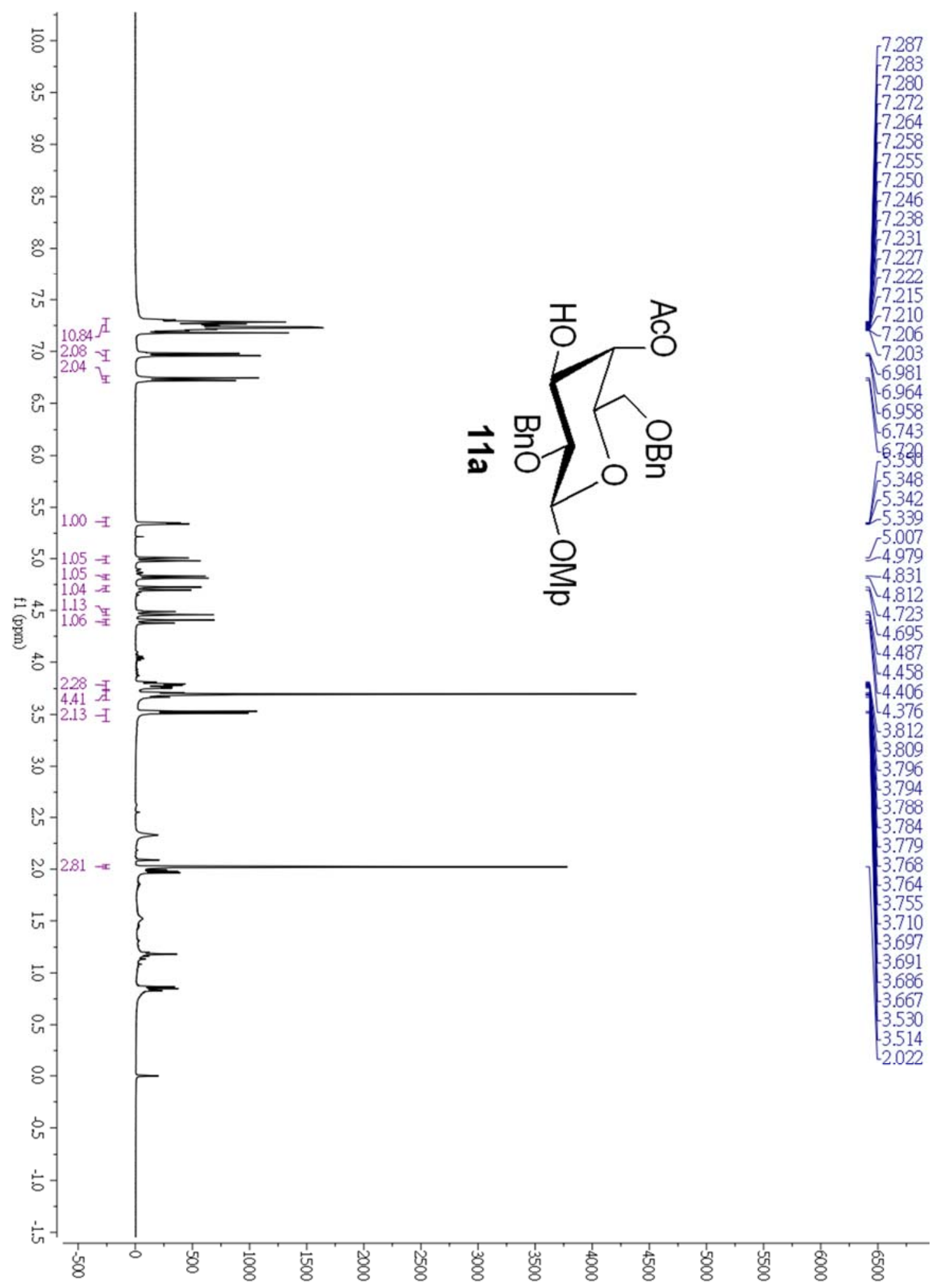


${ }^{1} \mathrm{H}$ spectrum of compound $\mathbf{1 1 b}\left(400 \mathrm{MHz}, \mathrm{CDCl}_{3}\right)$




${ }^{1} \mathrm{H}$ spectrum of compound $11 \mathrm{c}\left(400 \mathrm{MHz}, \mathrm{CDCl}_{3}\right)$

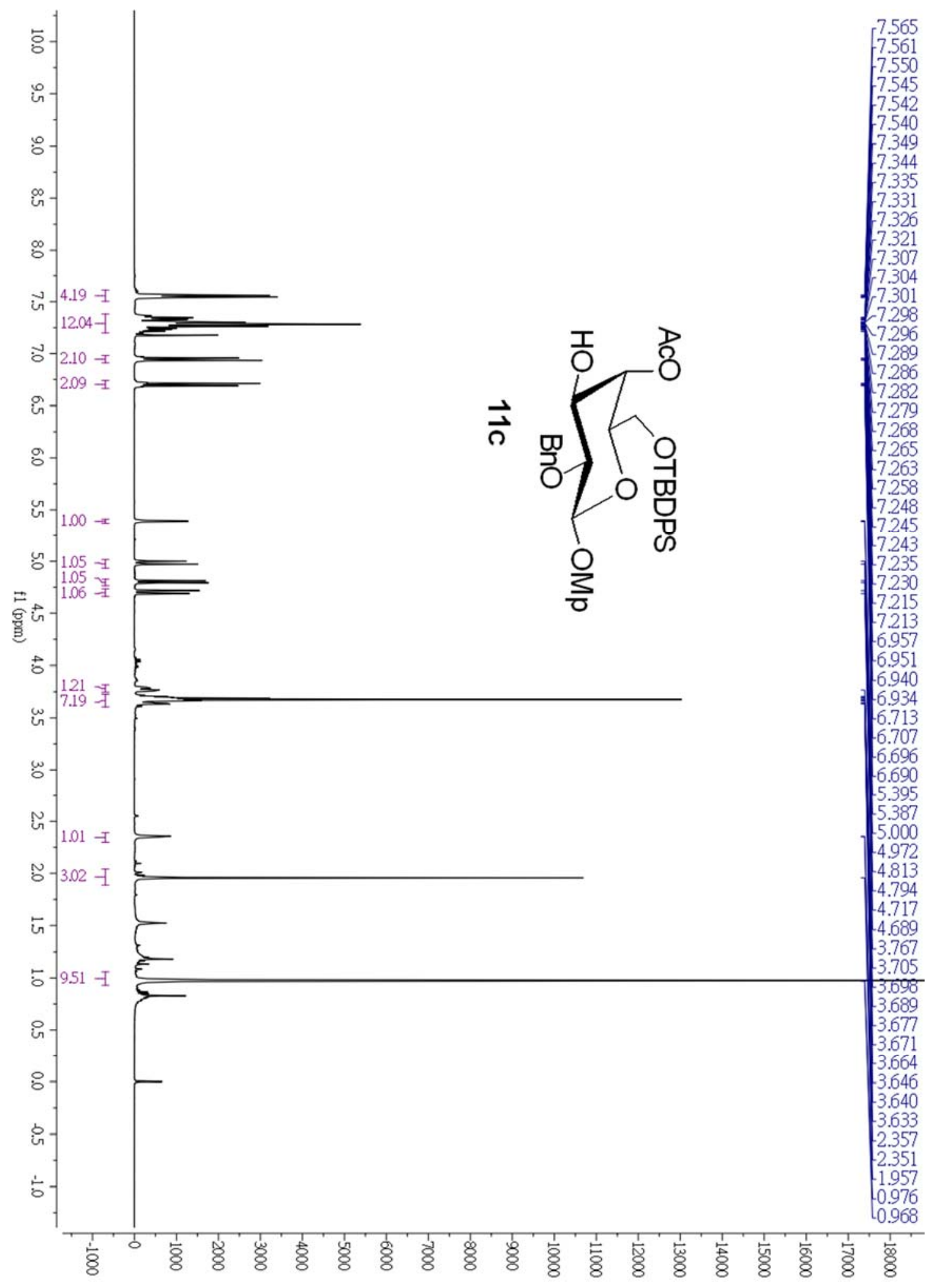


${ }^{1} \mathrm{H}-{ }^{1} \mathrm{H}$ COSY of compound 11c

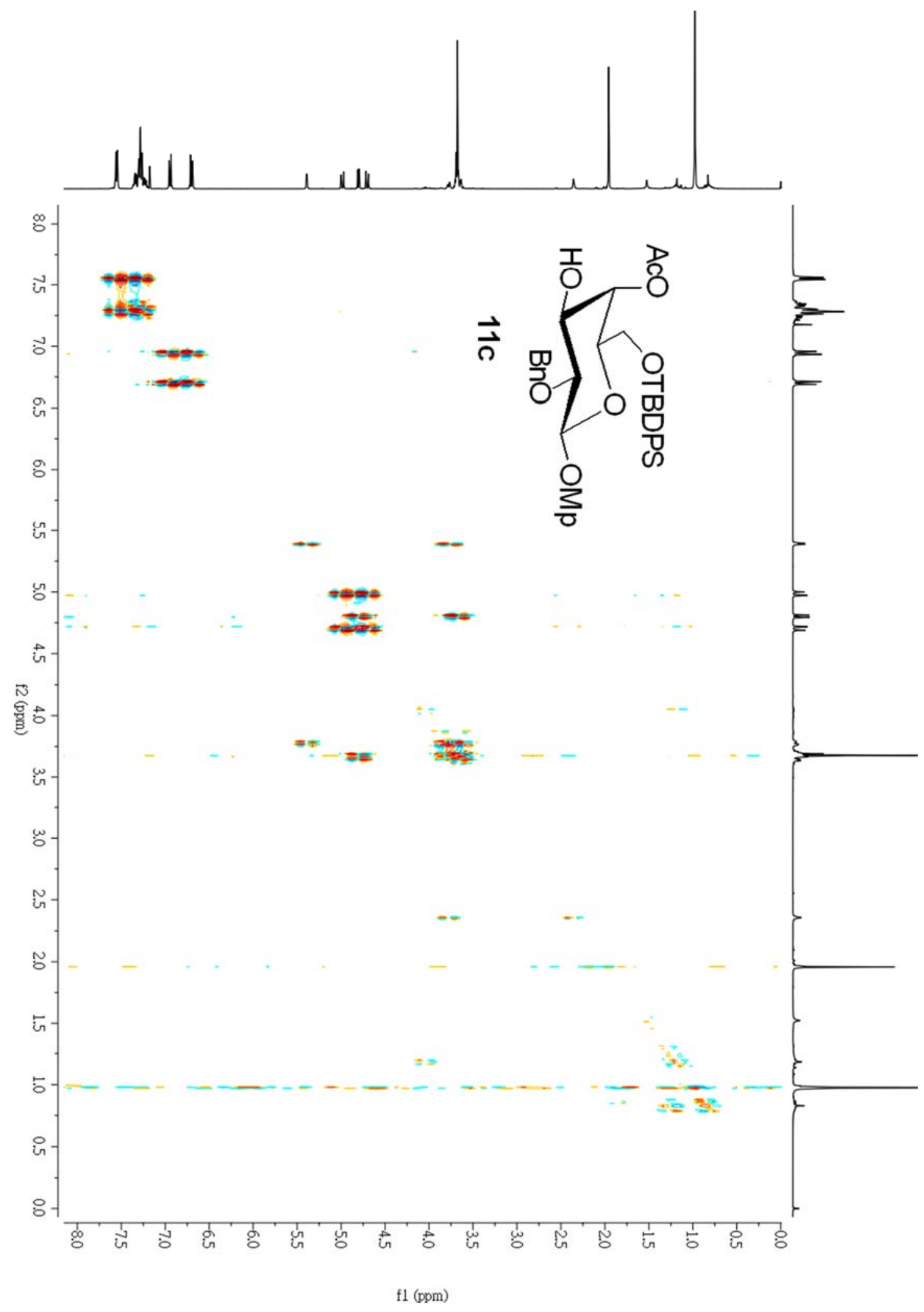


HSQC of compound 11c

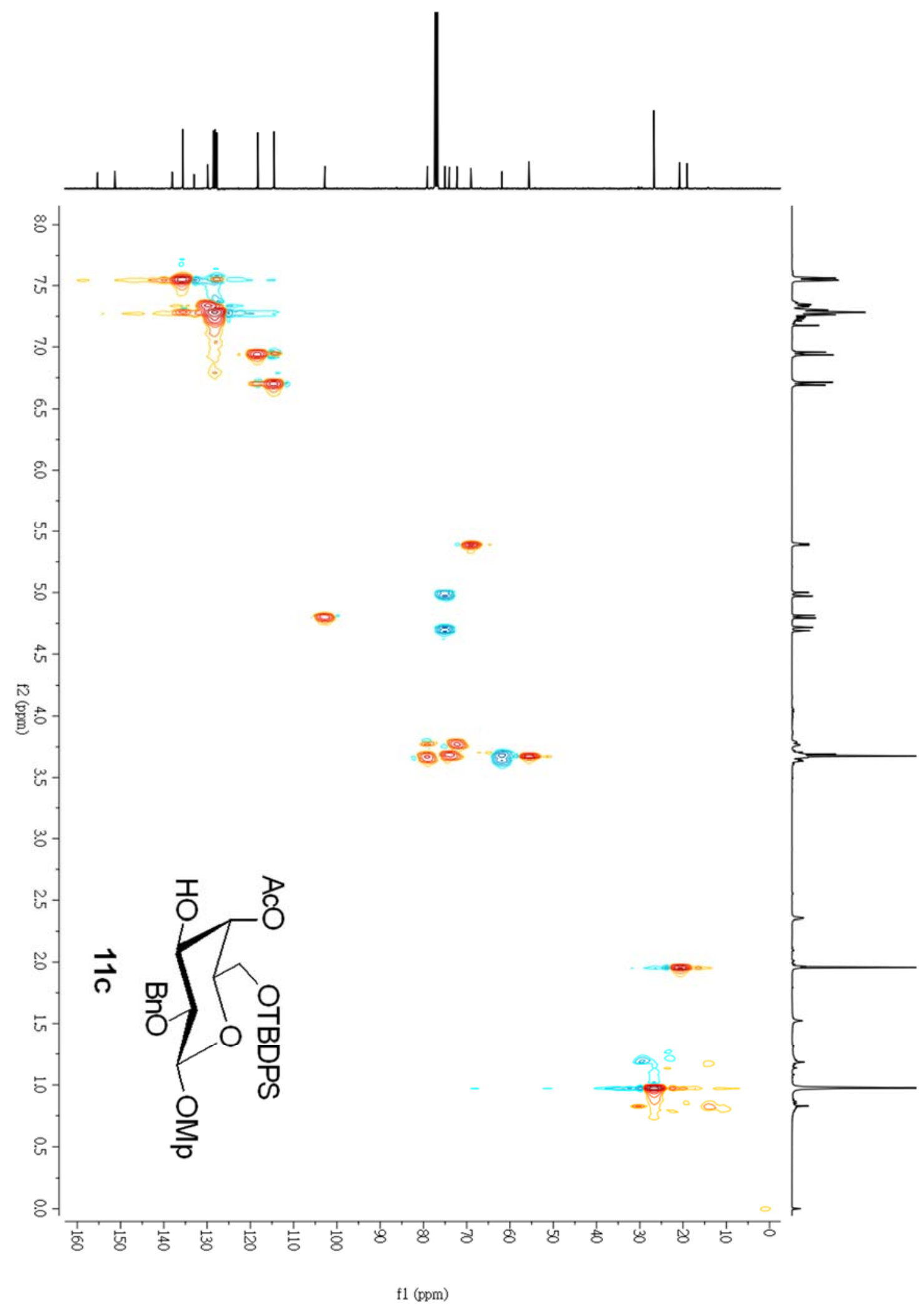


${ }^{13} \mathrm{C}$ spectrum of compound $11 \mathrm{c}\left(100 \mathrm{MHz}, \mathrm{CDCl}_{3}\right)$

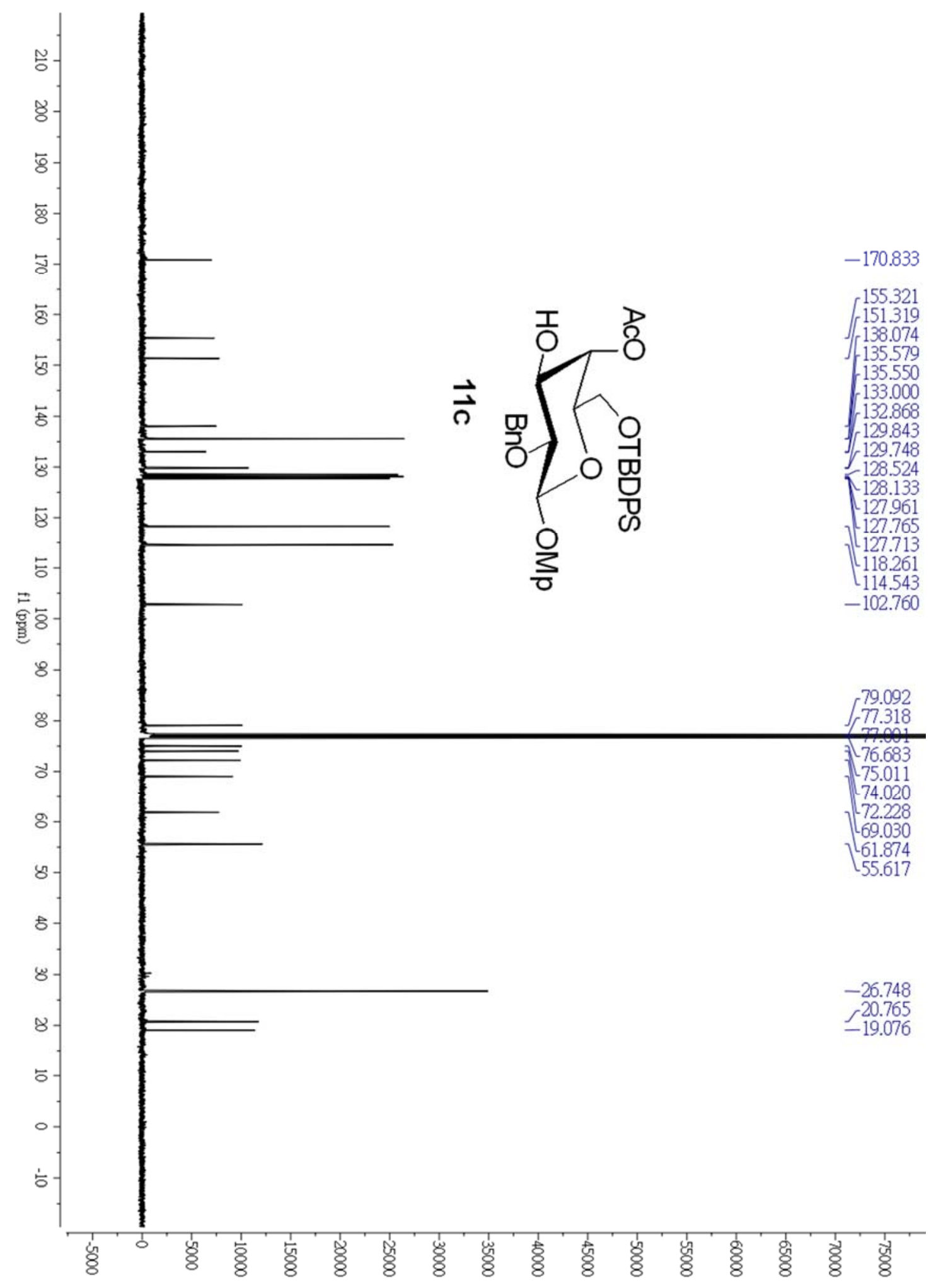


${ }^{1} \mathrm{H}$ spectrum of compound $11 \mathrm{e}\left(400 \mathrm{MHz}, \mathrm{CDCl}_{3}\right)$

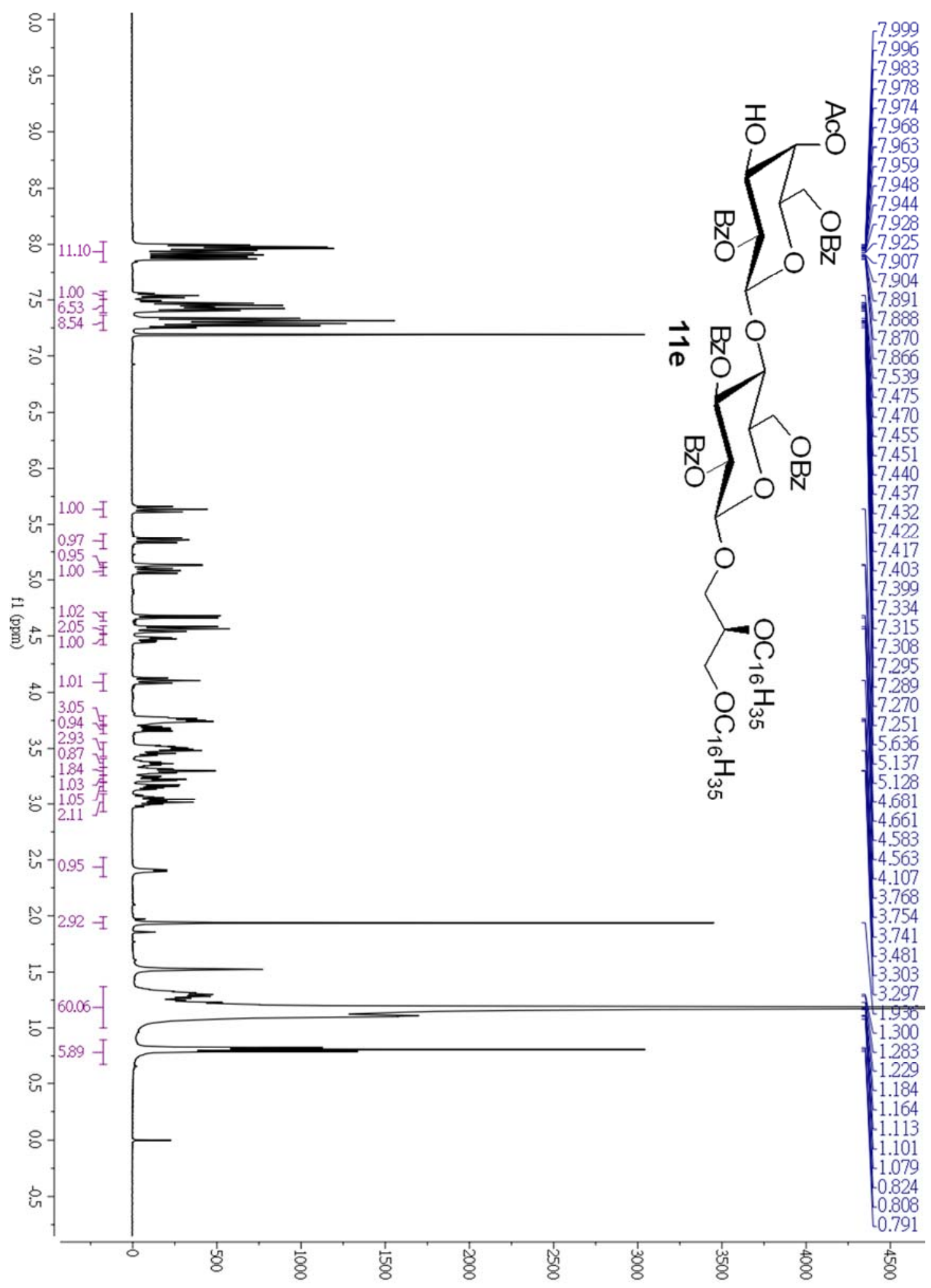


${ }^{1} \mathrm{H}-{ }^{1} \mathrm{H}$ COSY of compound 11e

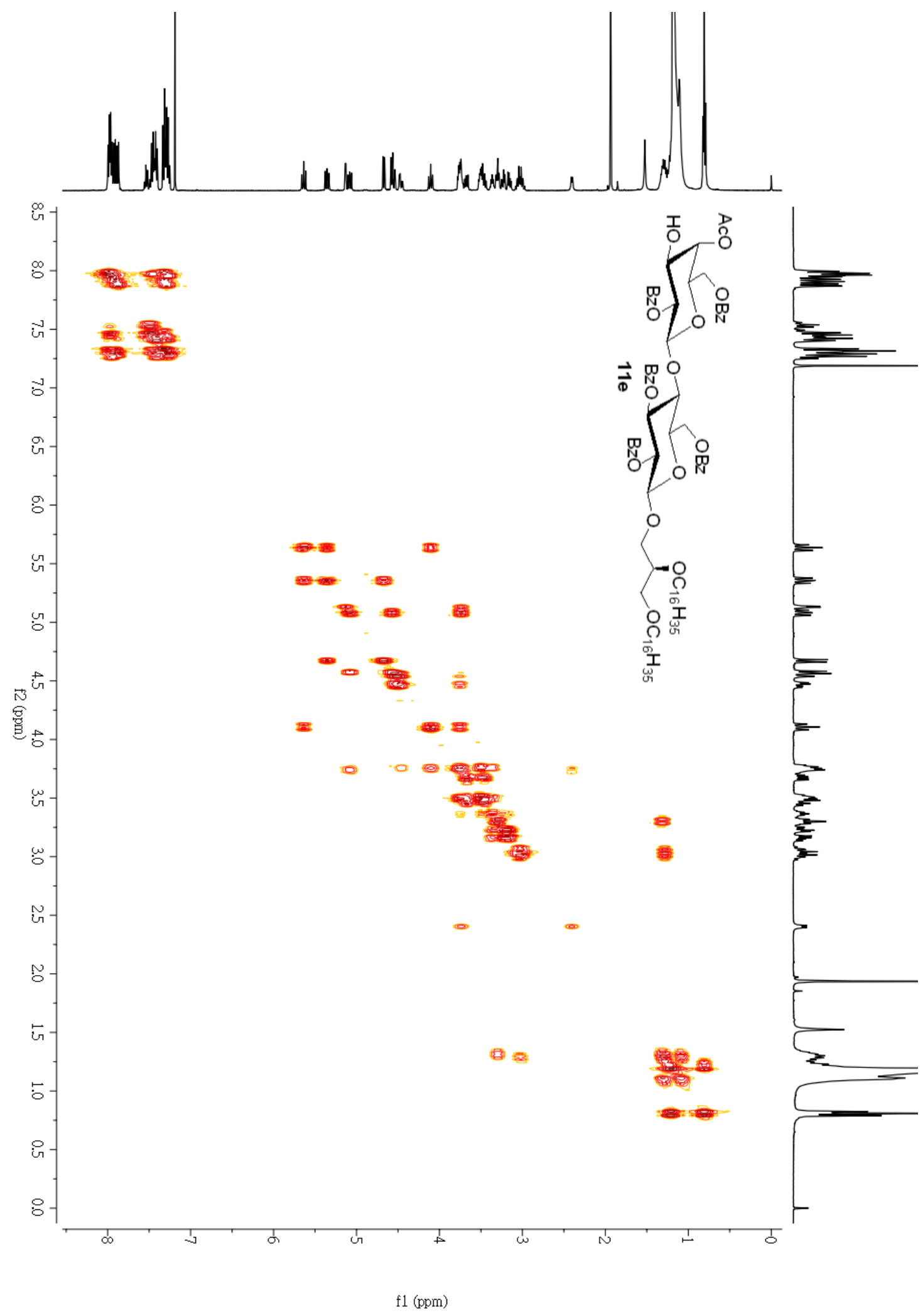




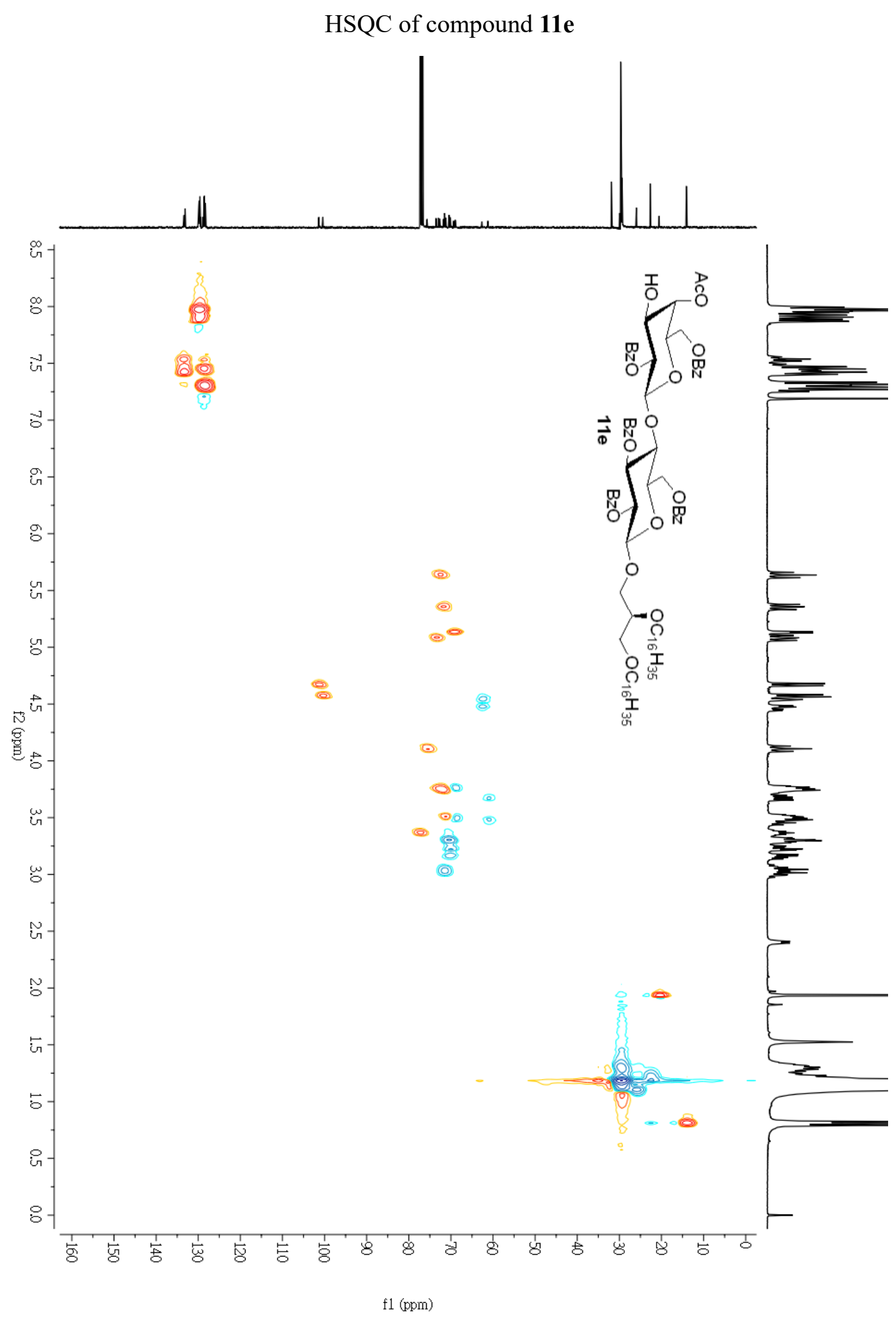


${ }^{13} \mathrm{C}$ spectrum of compound $11 \mathrm{e}\left(100 \mathrm{MHz}, \mathrm{CDCl}_{3}\right)$

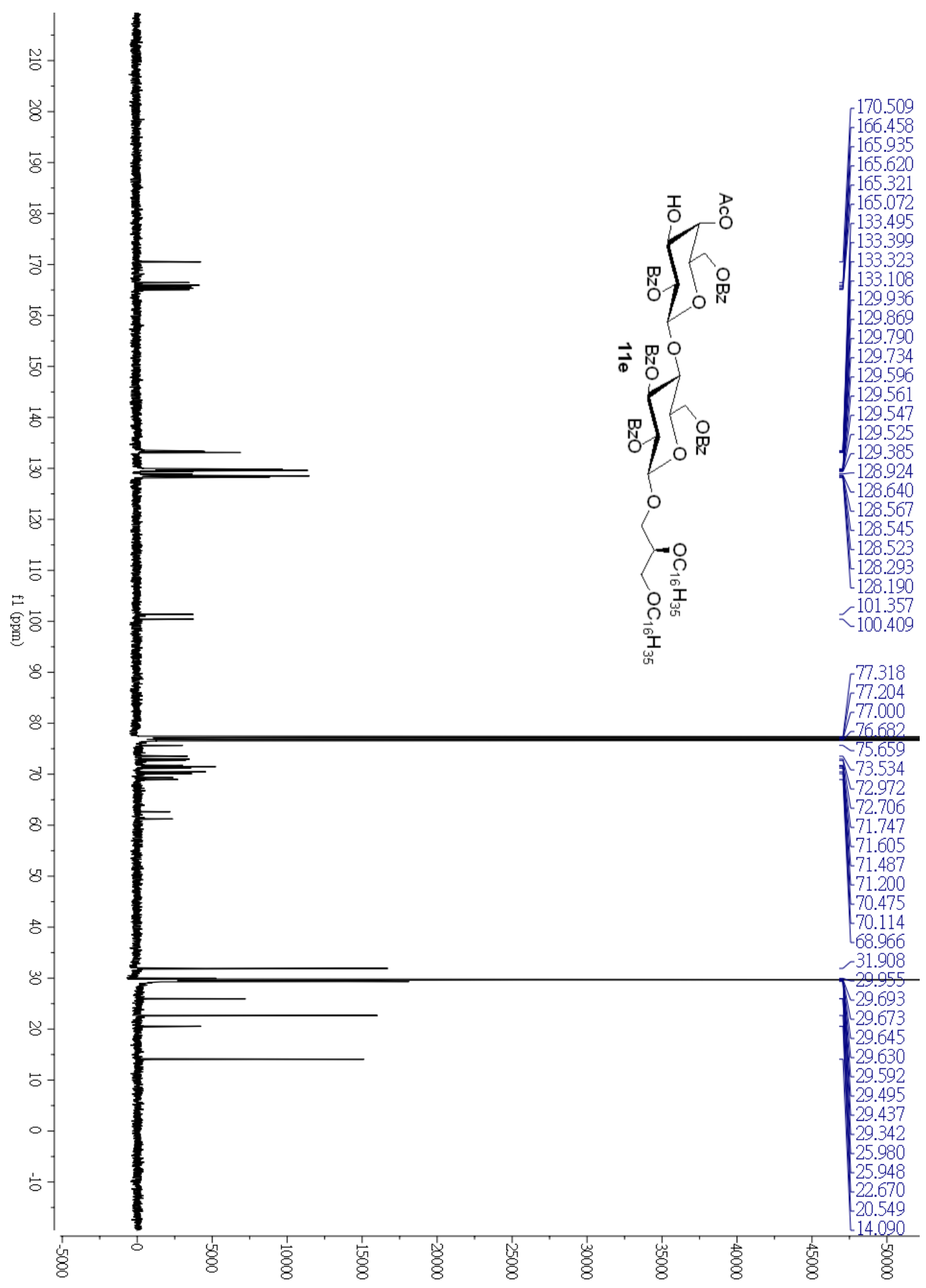


${ }^{1} \mathrm{H}$ spectrum of compound $\mathbf{1 1 g}\left(400 \mathrm{MHz}, \mathrm{CDCl}_{3}\right)$

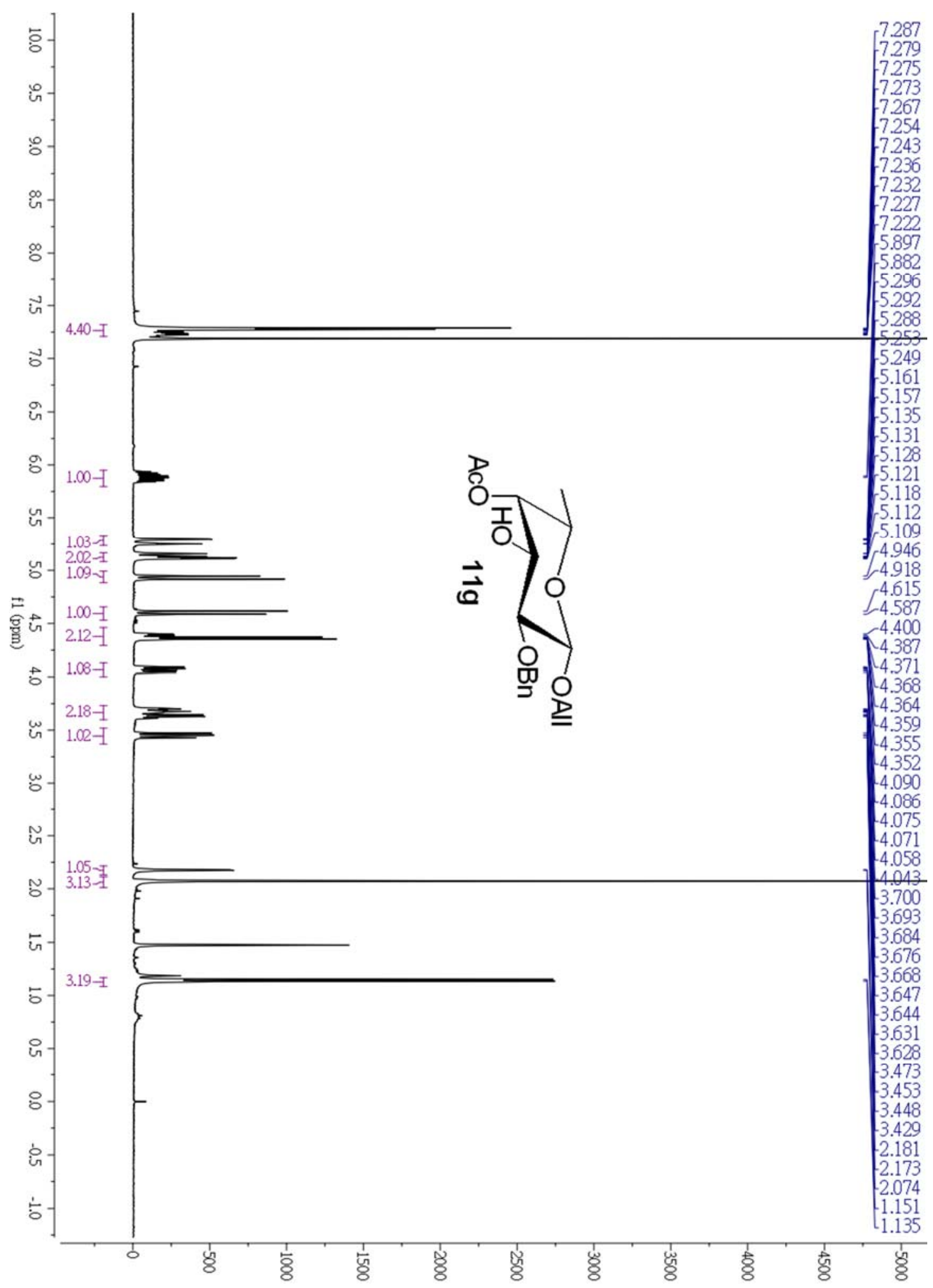


${ }^{1} \mathrm{H}-{ }^{1} \mathrm{H}$ COSY of compound $\mathbf{1 1 g}$

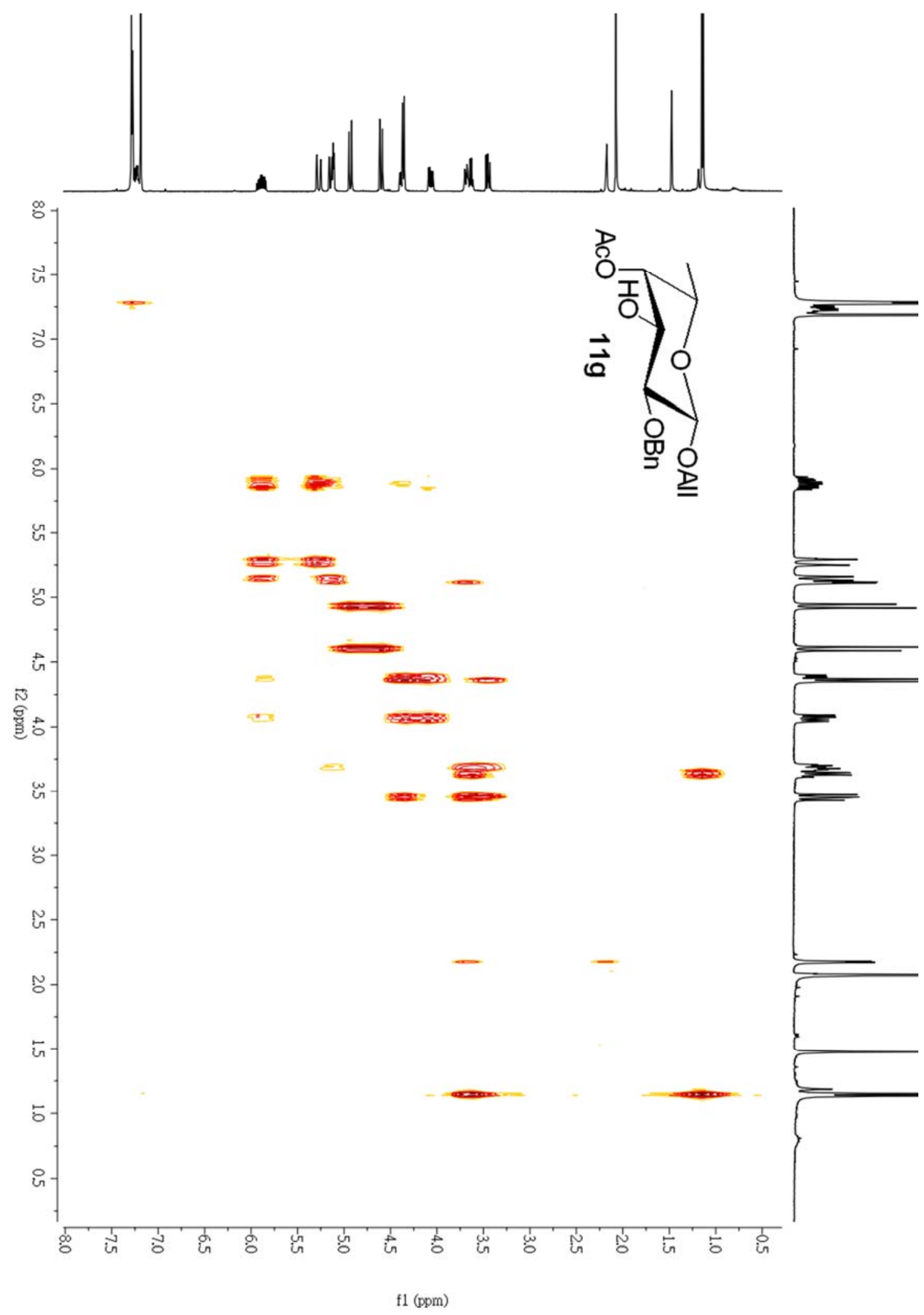


HSQC of compound $\mathbf{1 1 g}$






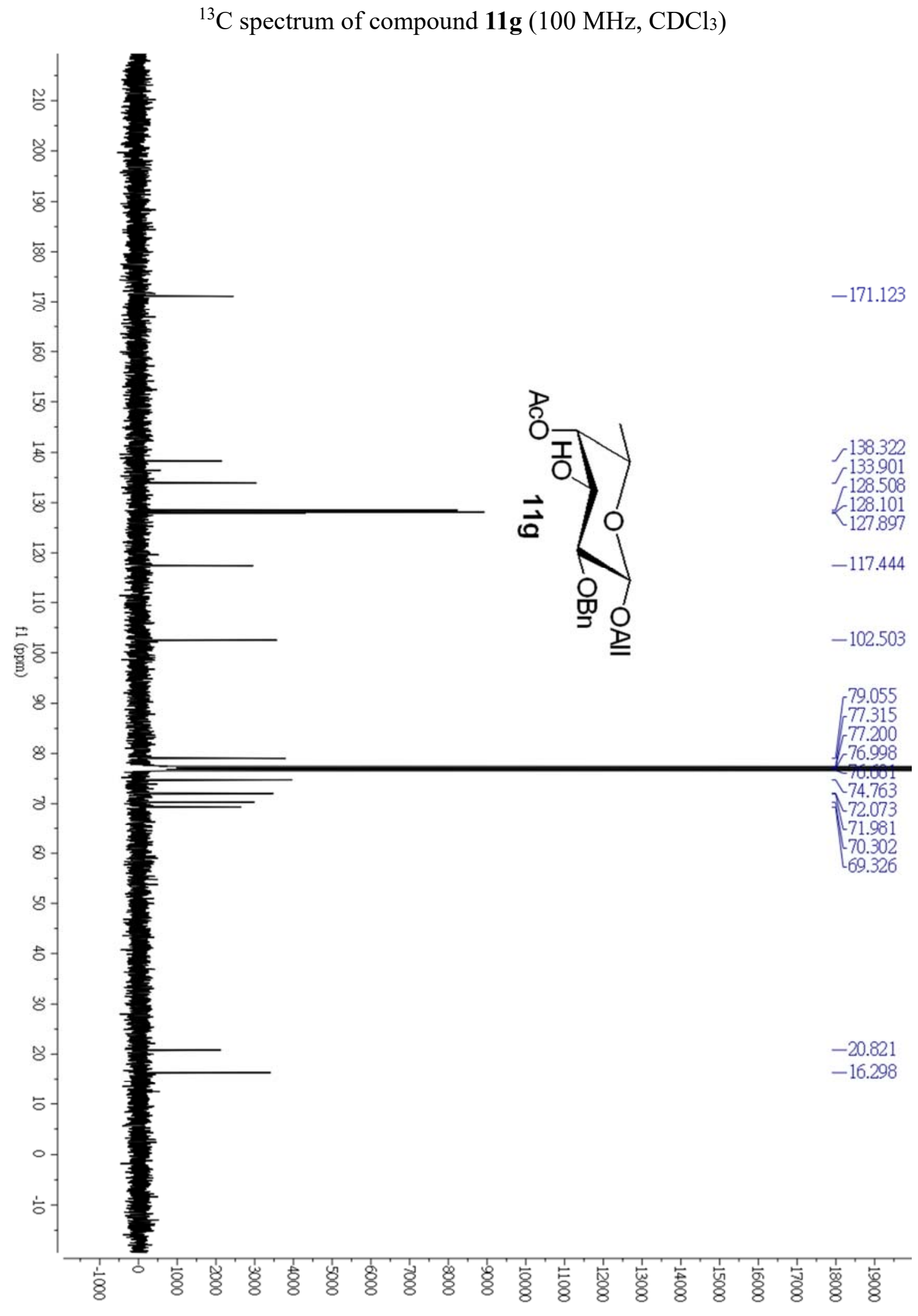


${ }^{1} \mathrm{H}$ spectrum of compound $\mathbf{1 1 h}\left(400 \mathrm{MHz}, \mathrm{CDCl}_{3}\right)$

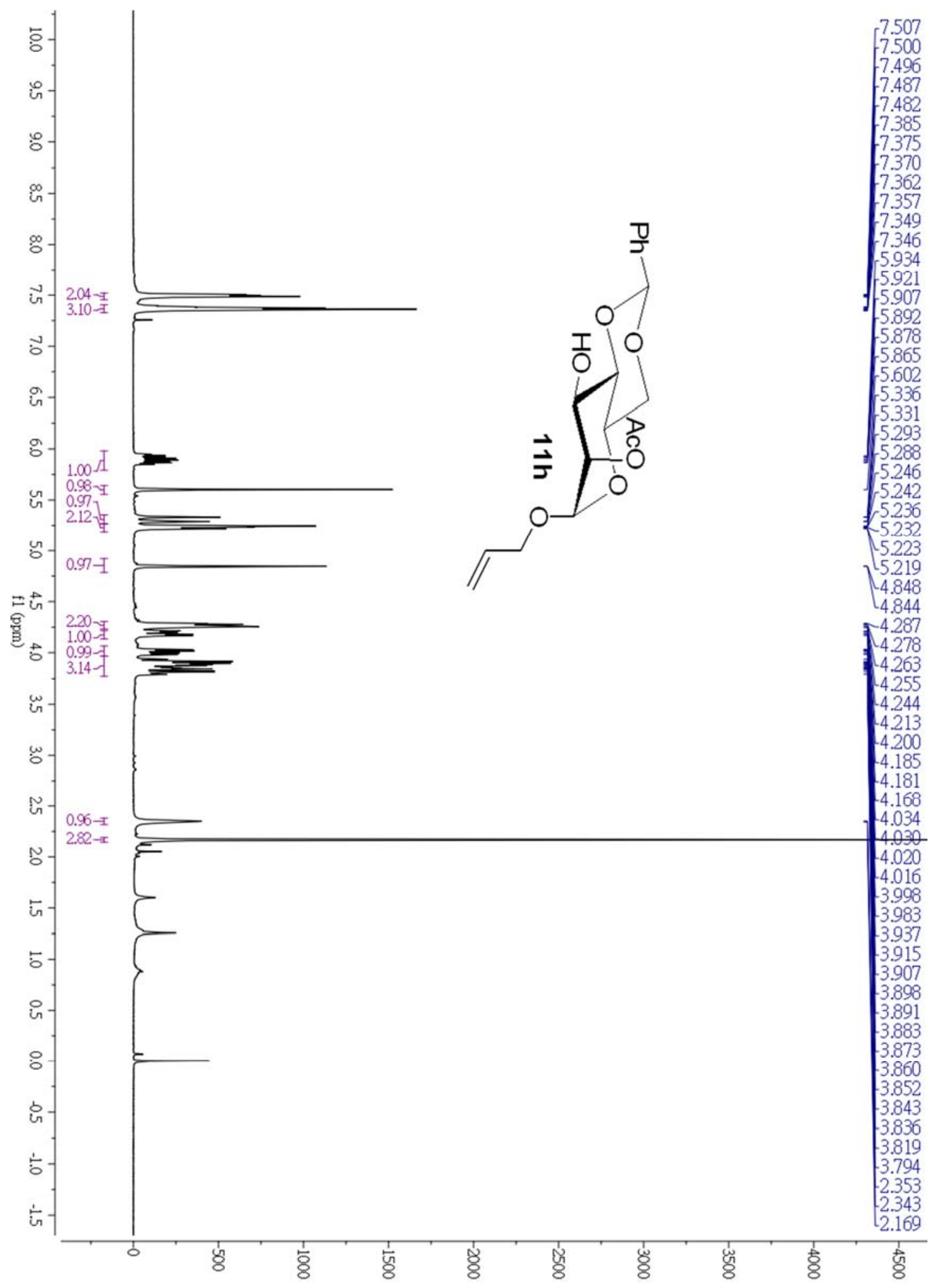


${ }^{1} \mathrm{H}$ spectrum of compound 13a $\left(400 \mathrm{MHz}, \mathrm{CDCl}_{3}\right)$

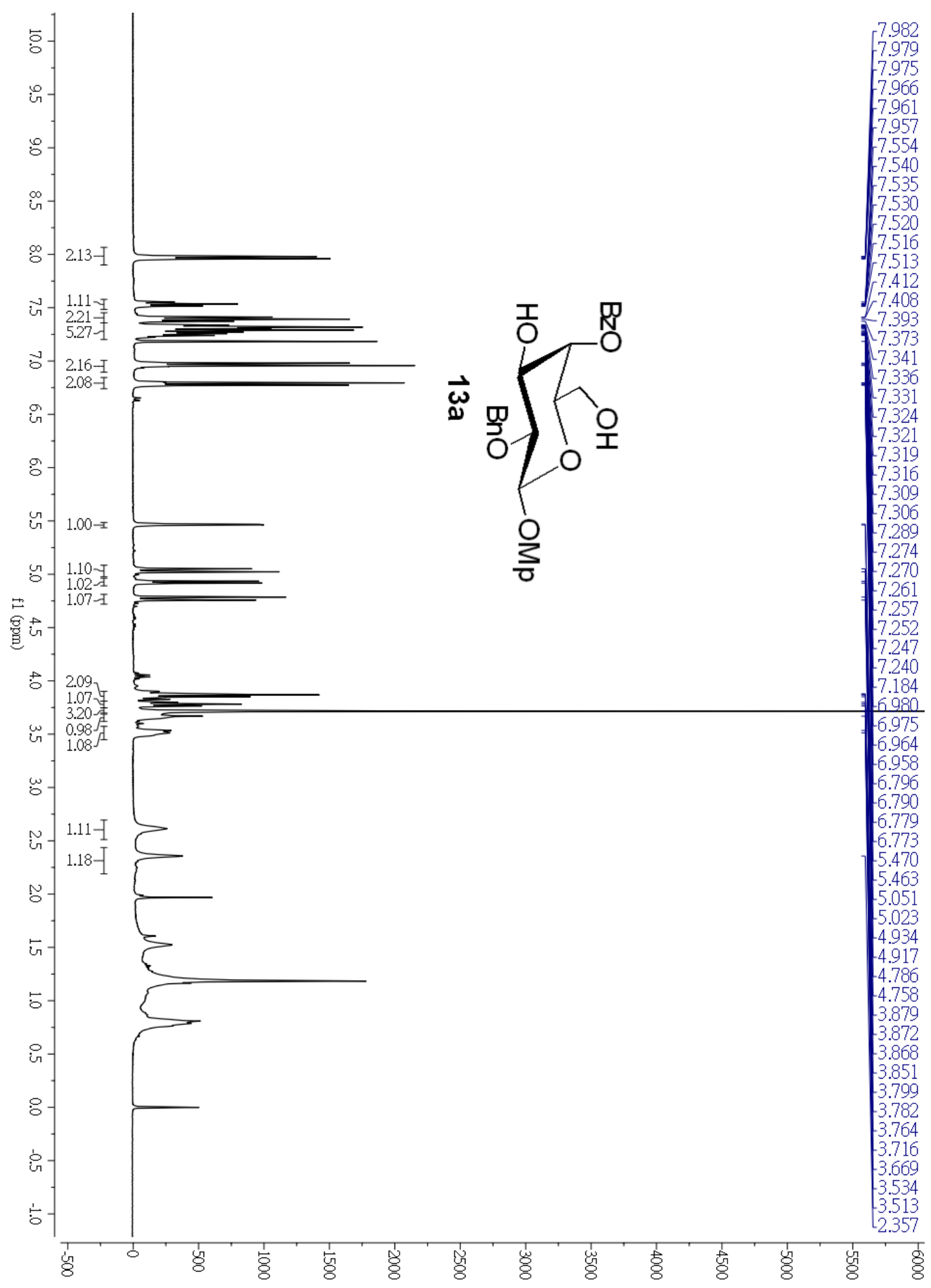

${ }^{1} \mathrm{H}-{ }^{1} \mathrm{H}$ COSY of compound $\mathbf{1 3 a}$ 


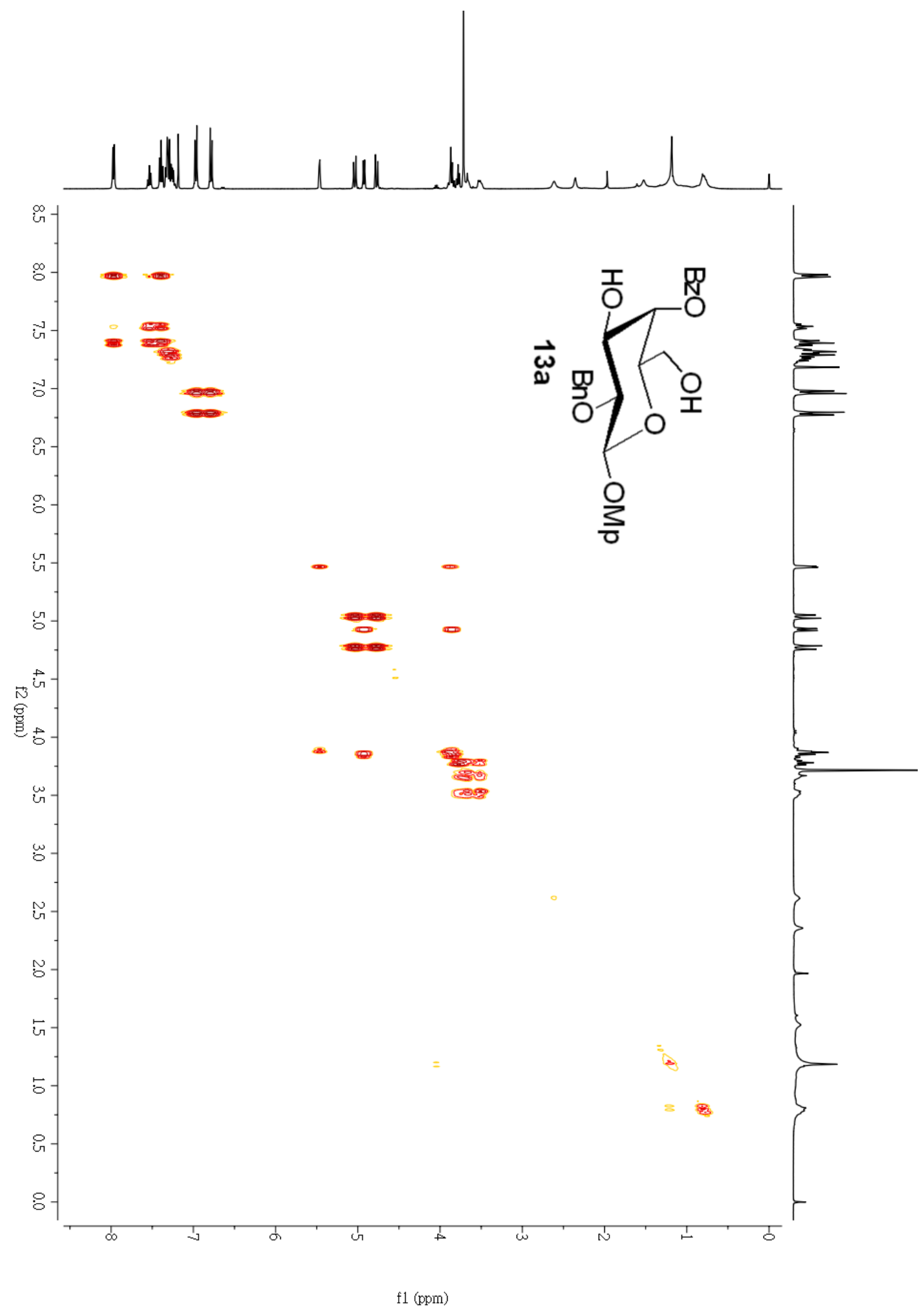

HSQC of compound 13a 


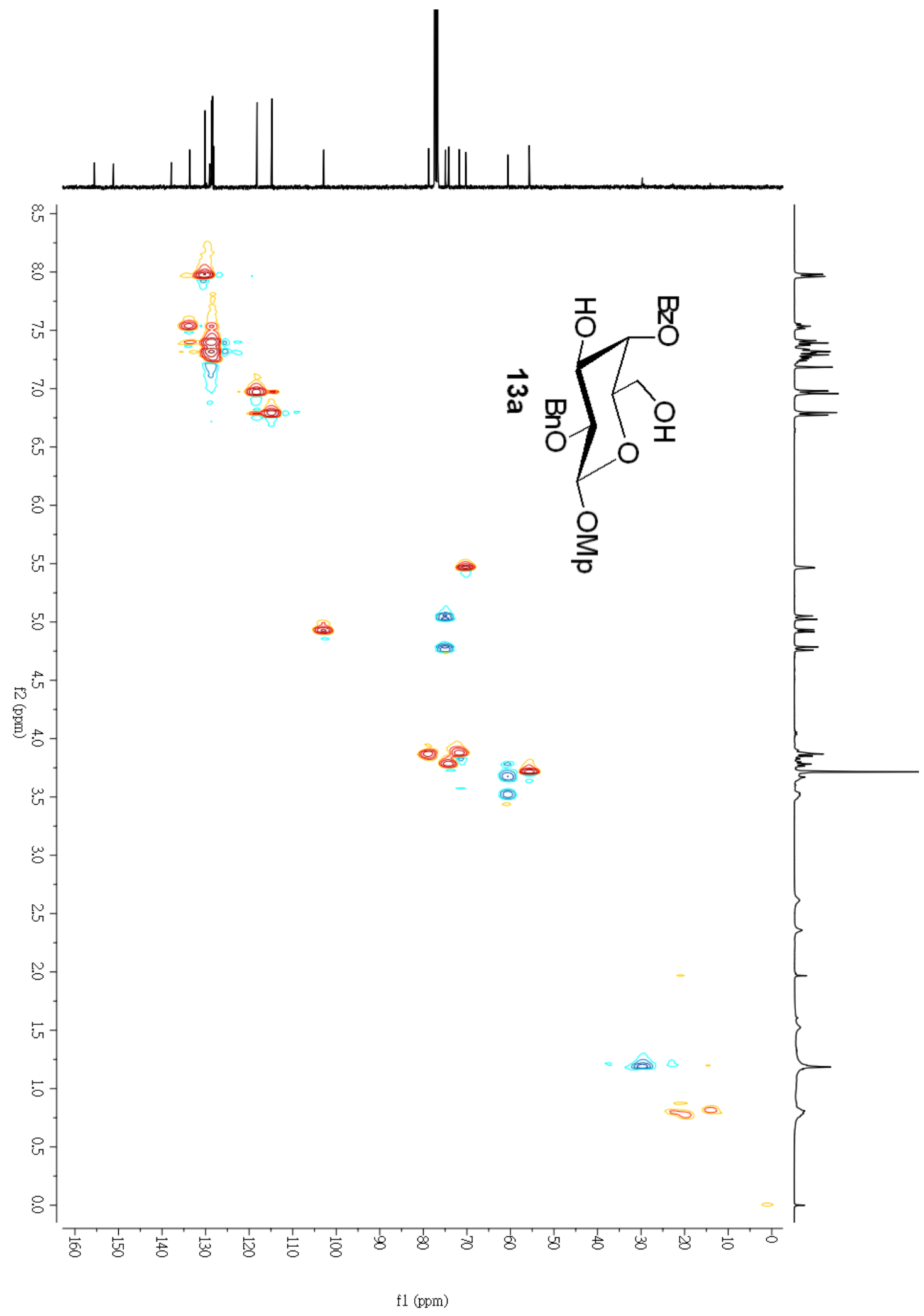

${ }^{13} \mathrm{C}$ spectrum of compound $\mathbf{1 3 a}\left(100 \mathrm{MHz}, \mathrm{CDCl}_{3}\right)$ 


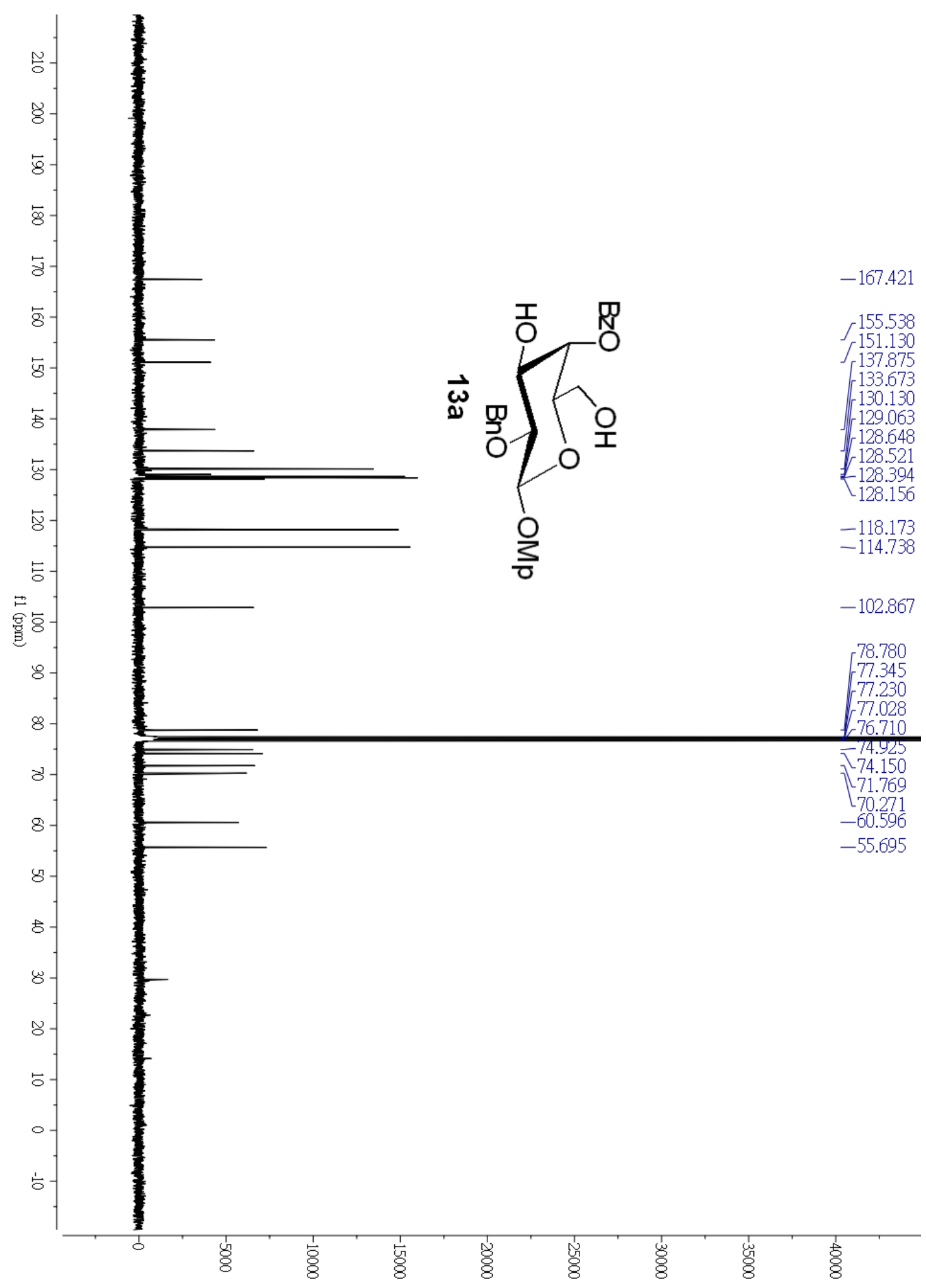

${ }^{1} \mathrm{H}$ spectrum of compound $\mathbf{1 4 a}\left(400 \mathrm{MHz}, \mathrm{CDCl}_{3}\right)$ 


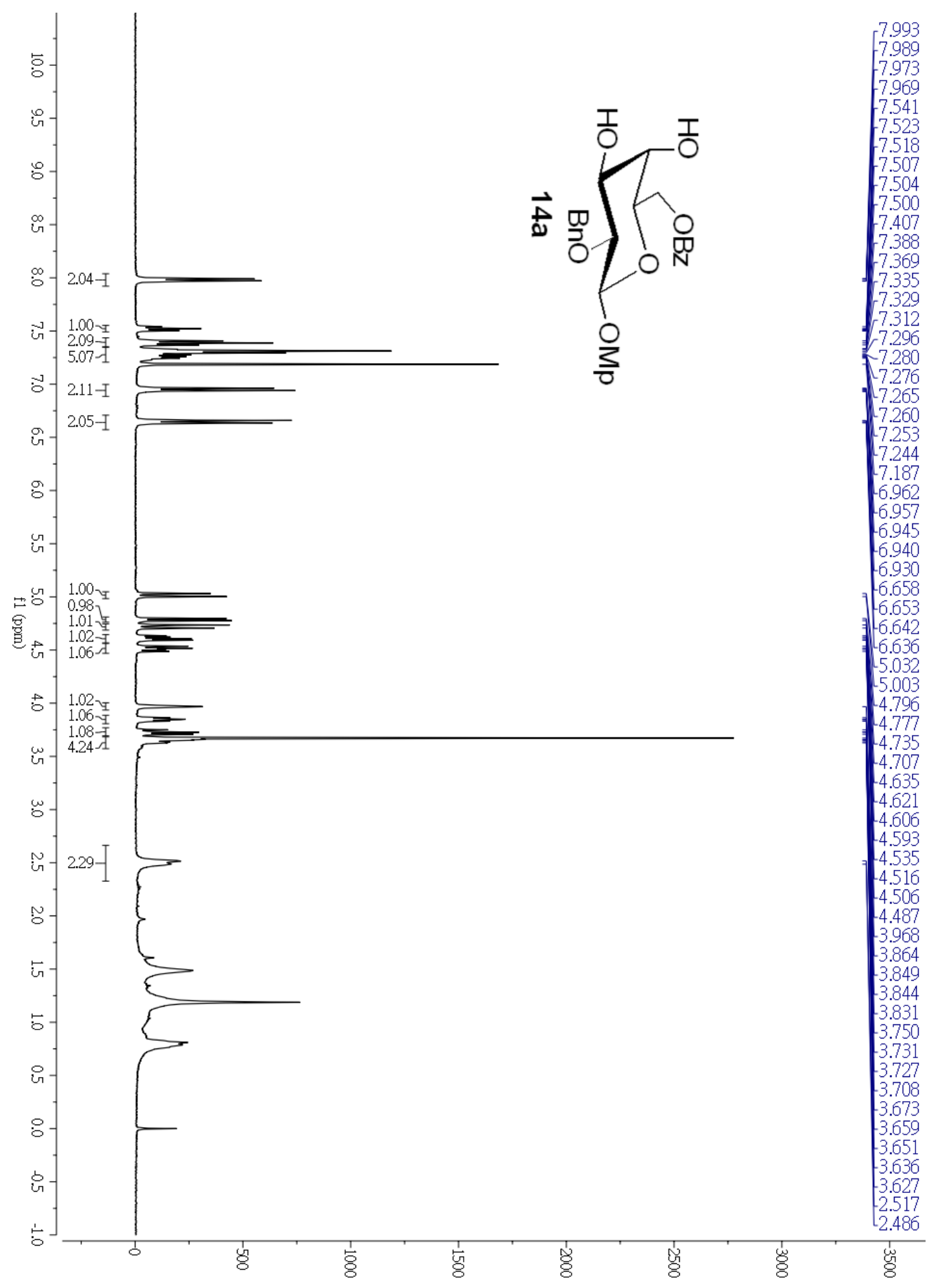

${ }^{1} \mathrm{H}-{ }^{1} \mathrm{H}$ COSY of compound $\mathbf{1 4 a}$ 


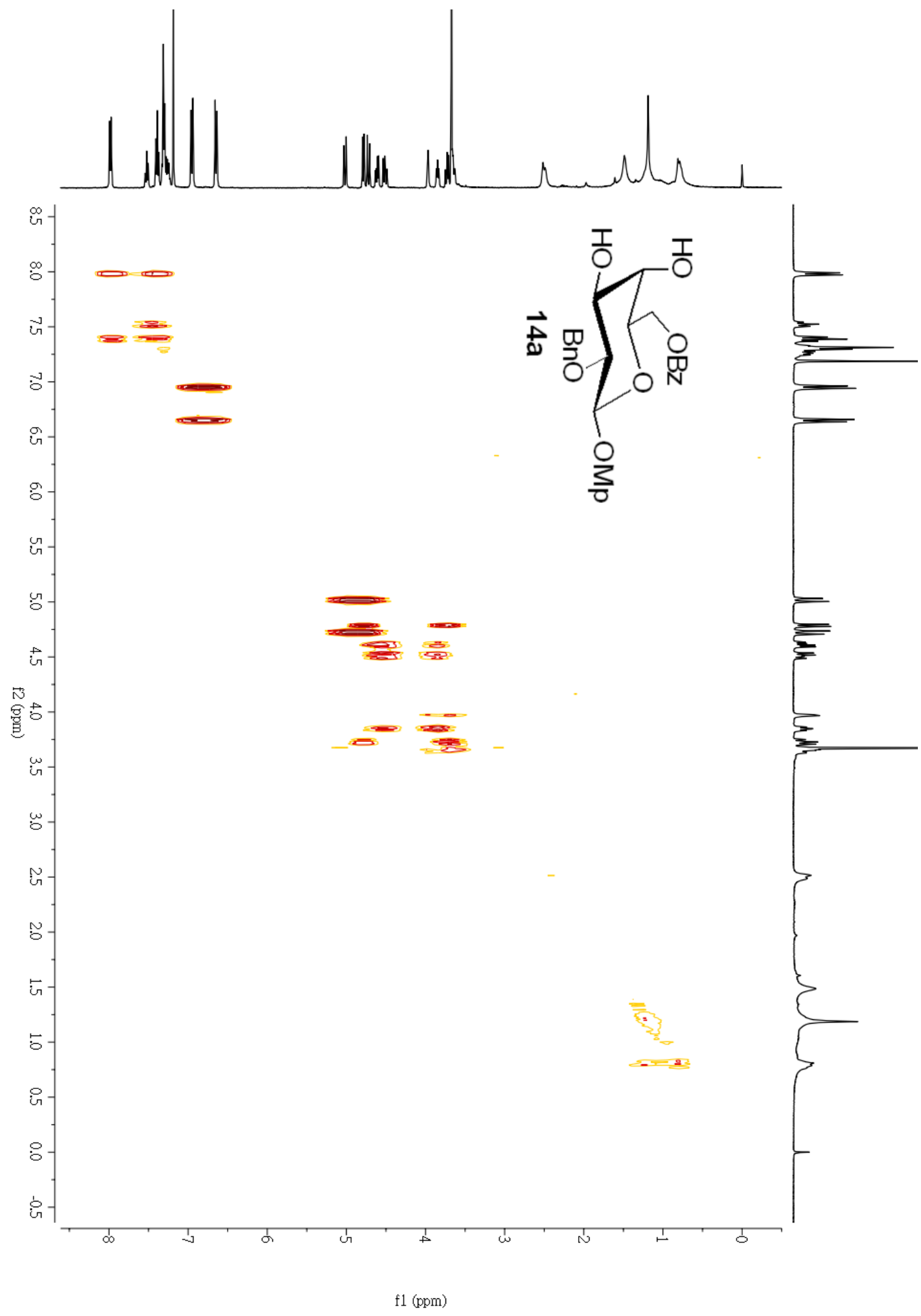

HSQC of compound $\mathbf{1 4 a}$ 


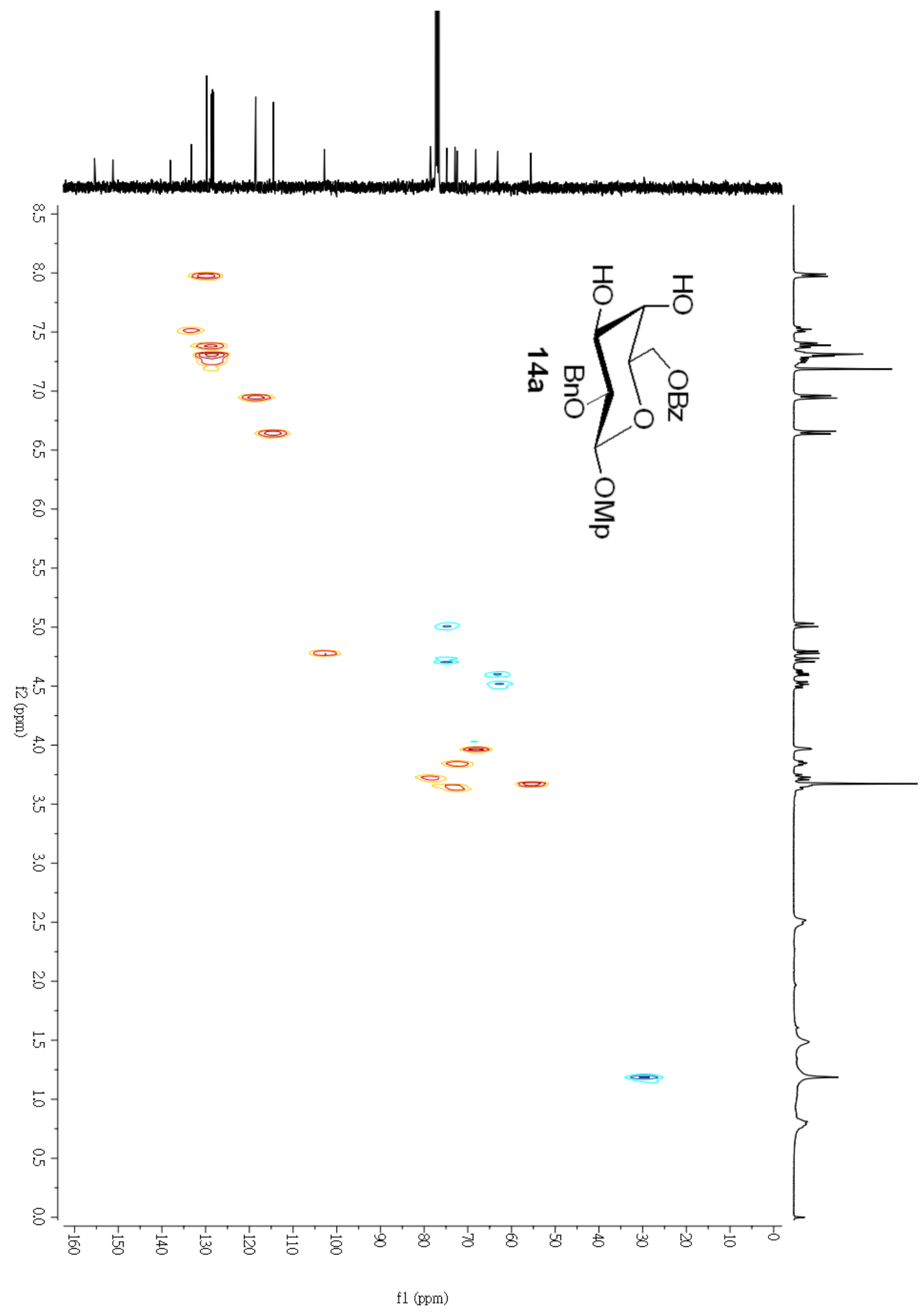

${ }^{13} \mathrm{C}$ spectrum of compound $\mathbf{1 4 a}\left(100 \mathrm{MHz}, \mathrm{CDCl}_{3}\right)$ 


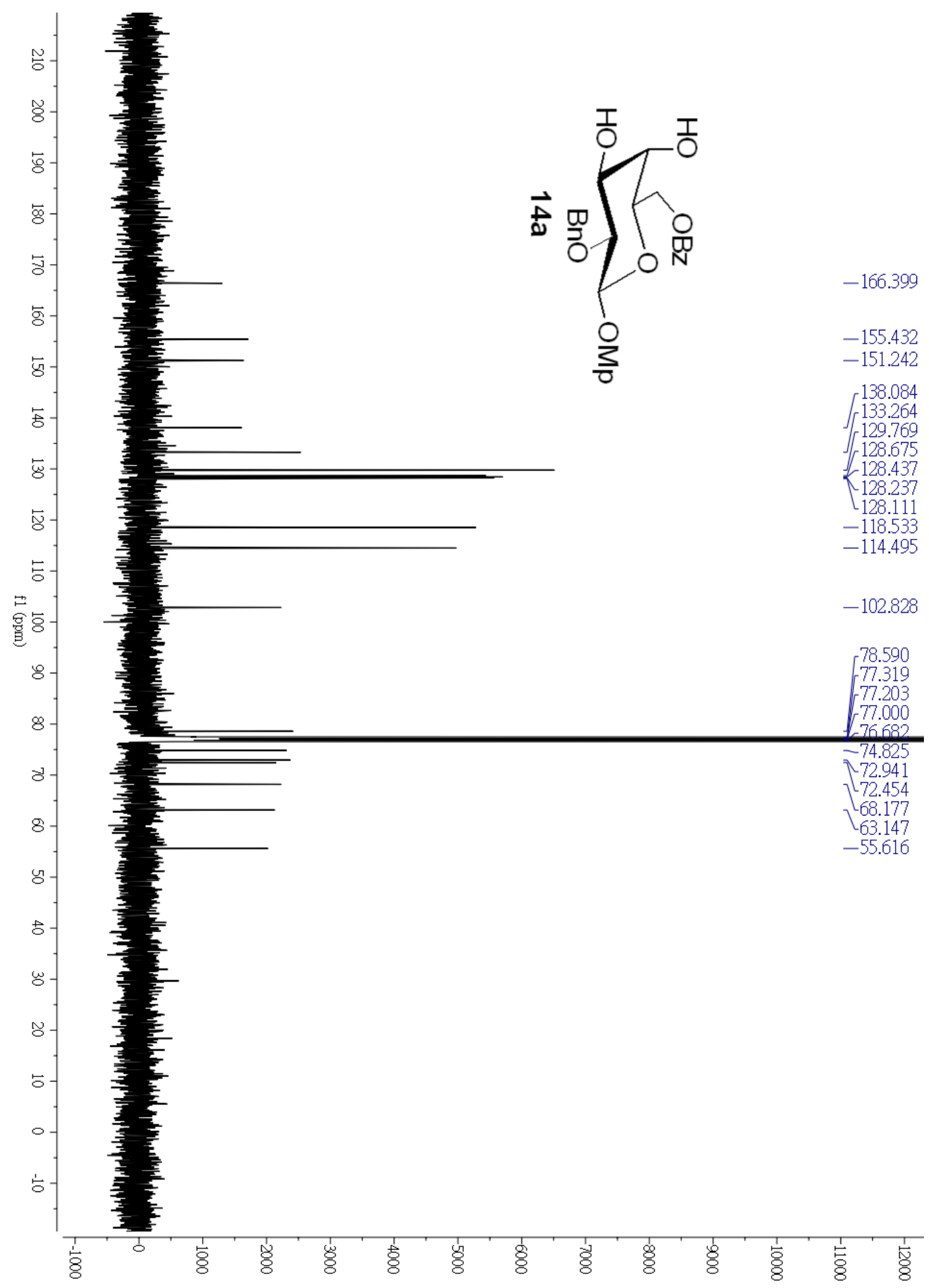

${ }^{1} \mathrm{H}$ spectrum of compound $\mathbf{1 5 a}\left(400 \mathrm{MHz}, \mathrm{CDCl}_{3}\right)$ 


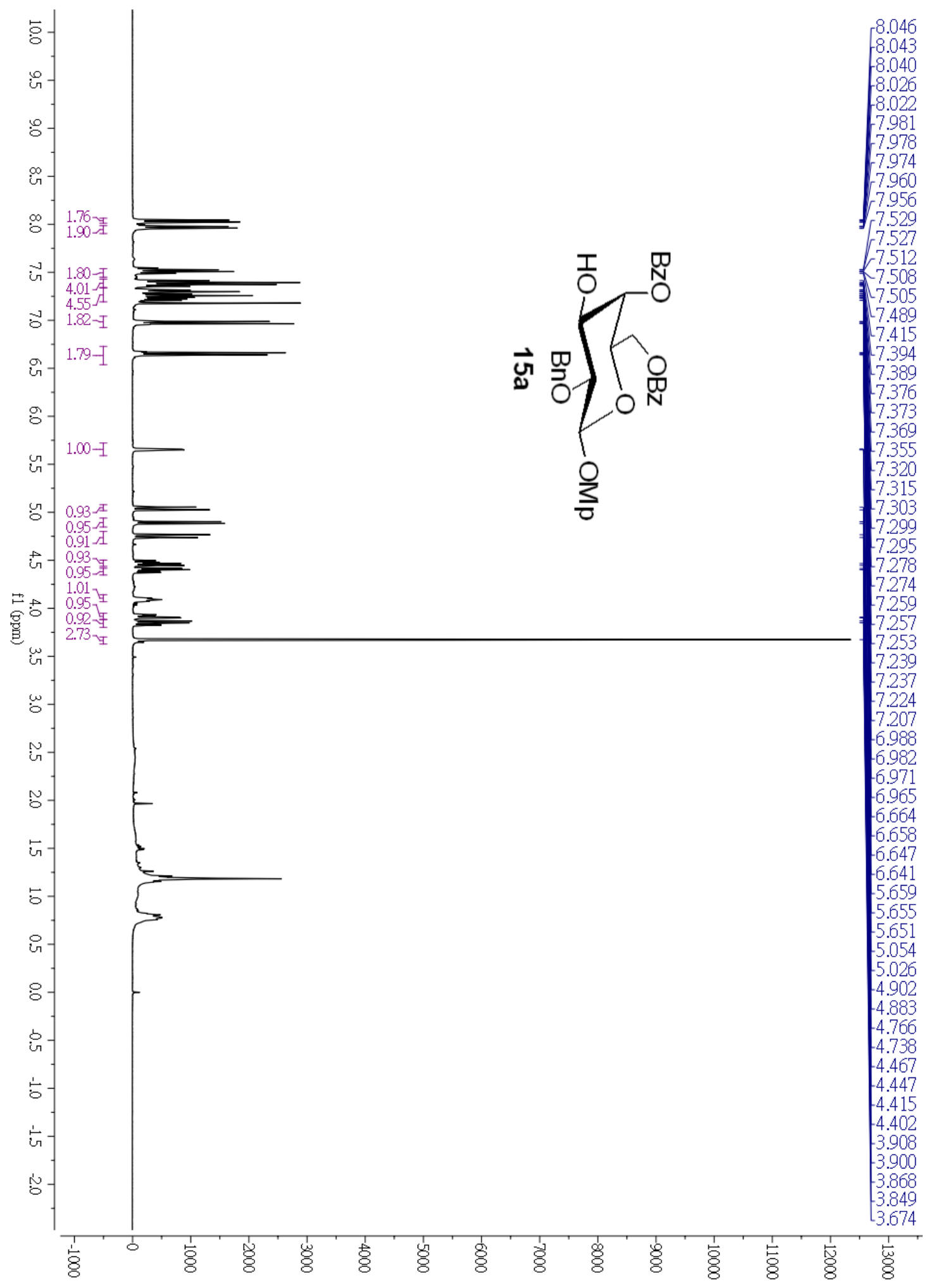


${ }^{1} \mathrm{H}-{ }^{1} \mathrm{H}$ COSY of compound $\mathbf{1 5 a}$

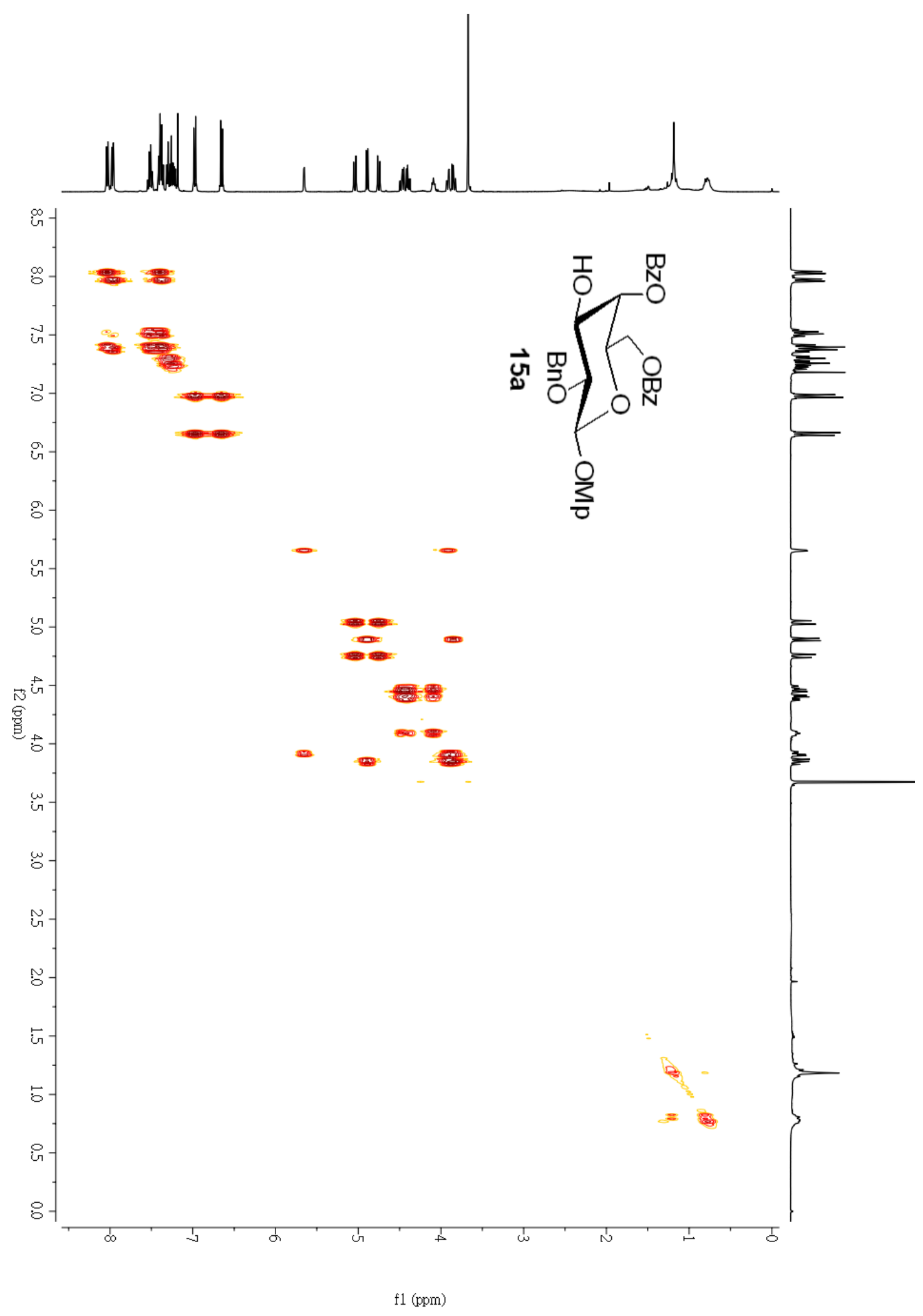


HSQC of compound 15a

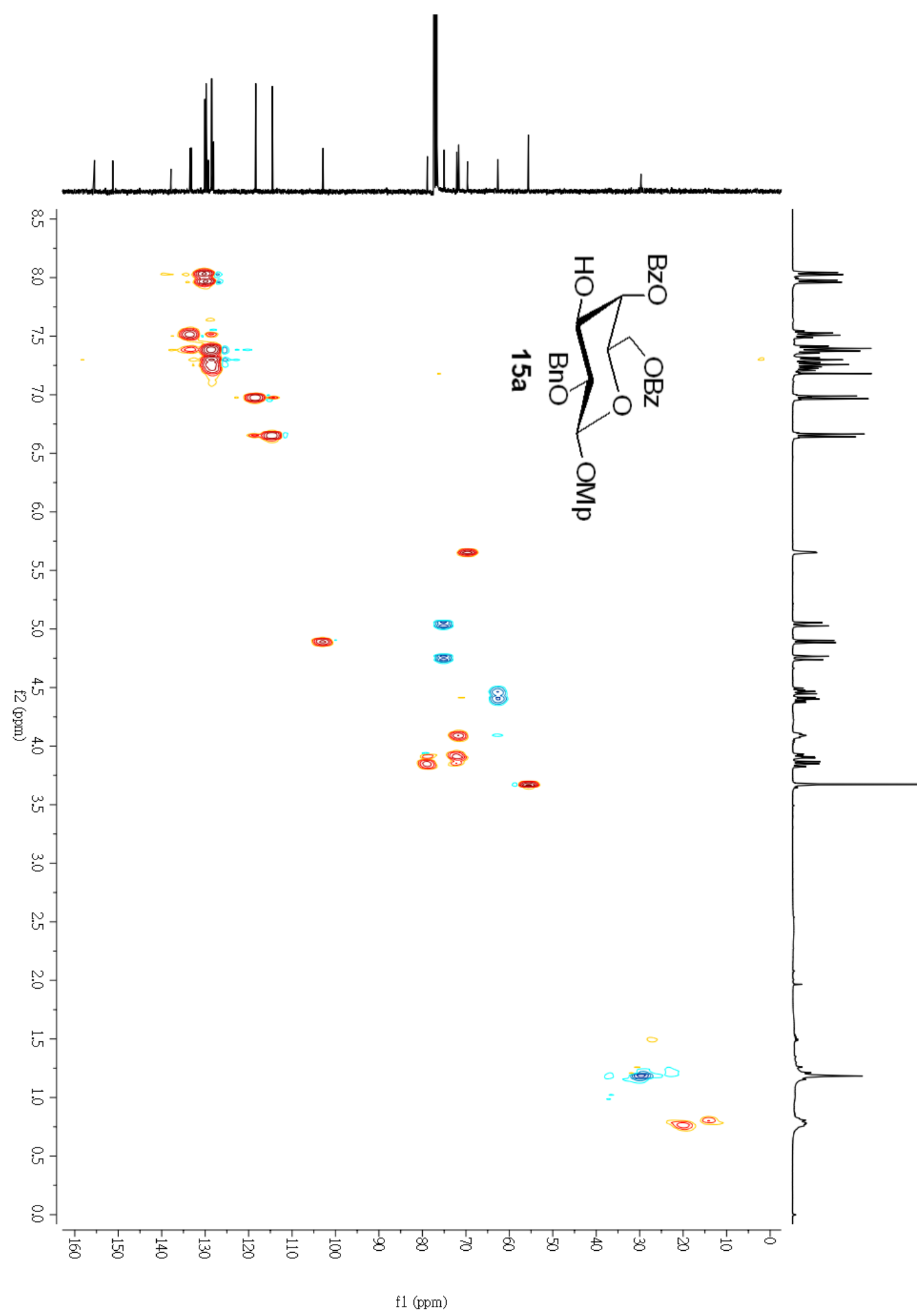


${ }^{13} \mathrm{C}$ spectrum of compound $15 \mathrm{a}\left(100 \mathrm{MHz}, \mathrm{CDCl}_{3}\right)$

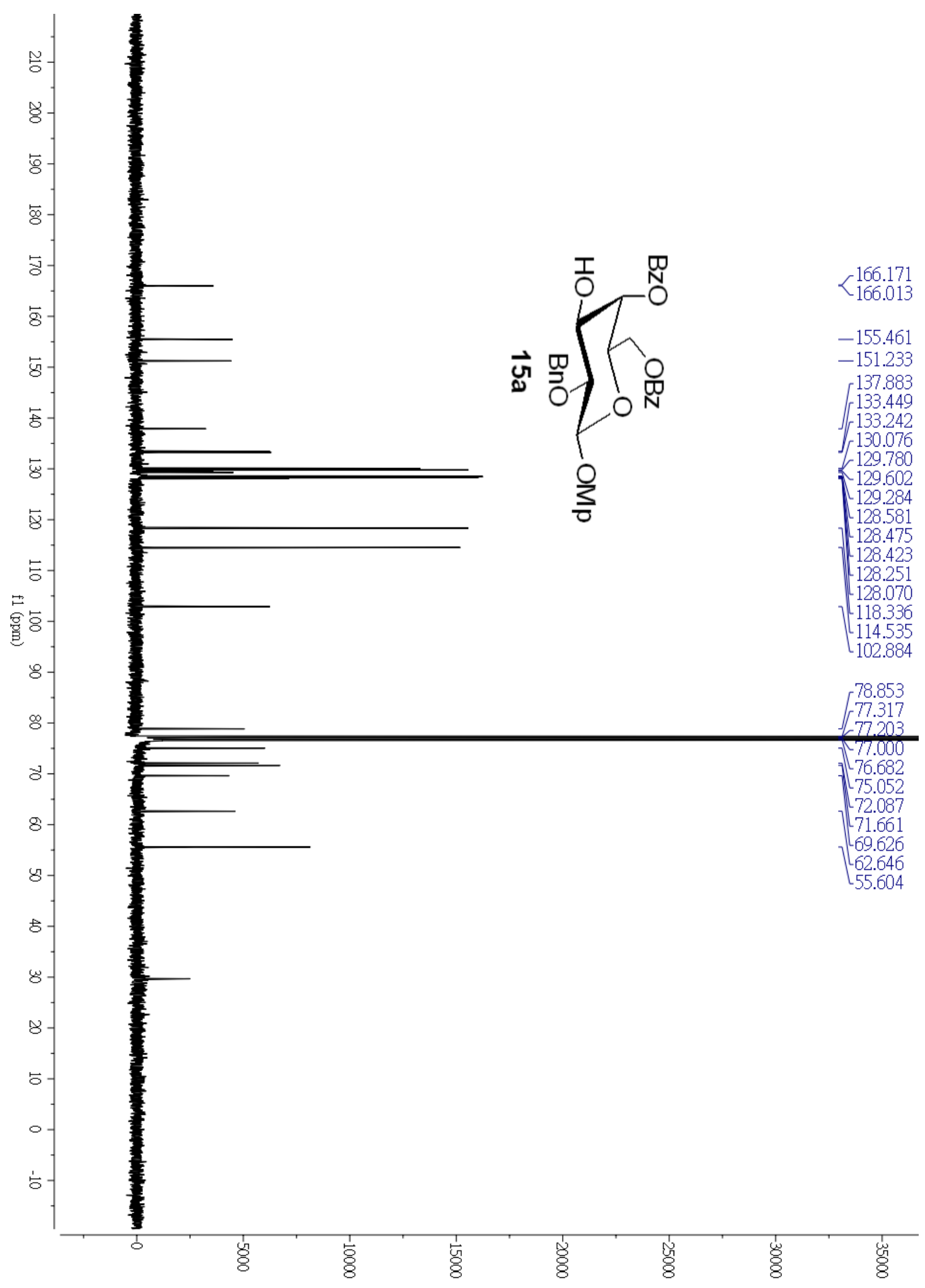


${ }^{1} \mathrm{H}$ spectrum of compound $13 \mathbf{b}\left(400 \mathrm{MHz}, \mathrm{CDCl}_{3}\right)$

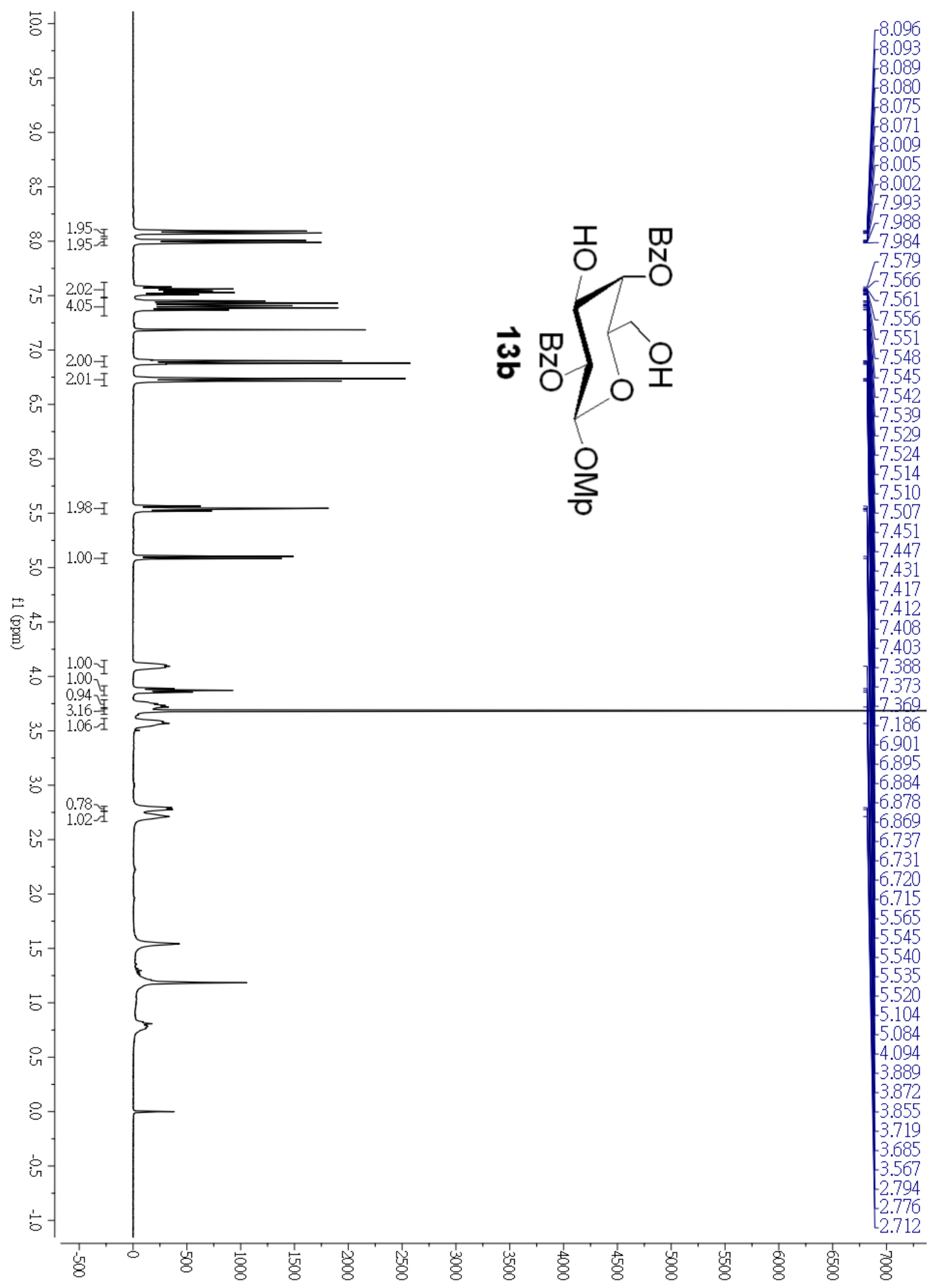







HSQC of compound $\mathbf{1 3 b}$




${ }^{13} \mathrm{C}$ spectrum of compound $\mathbf{1 3 b}\left(100 \mathrm{MHz}, \mathrm{CDCl}_{3}\right)$

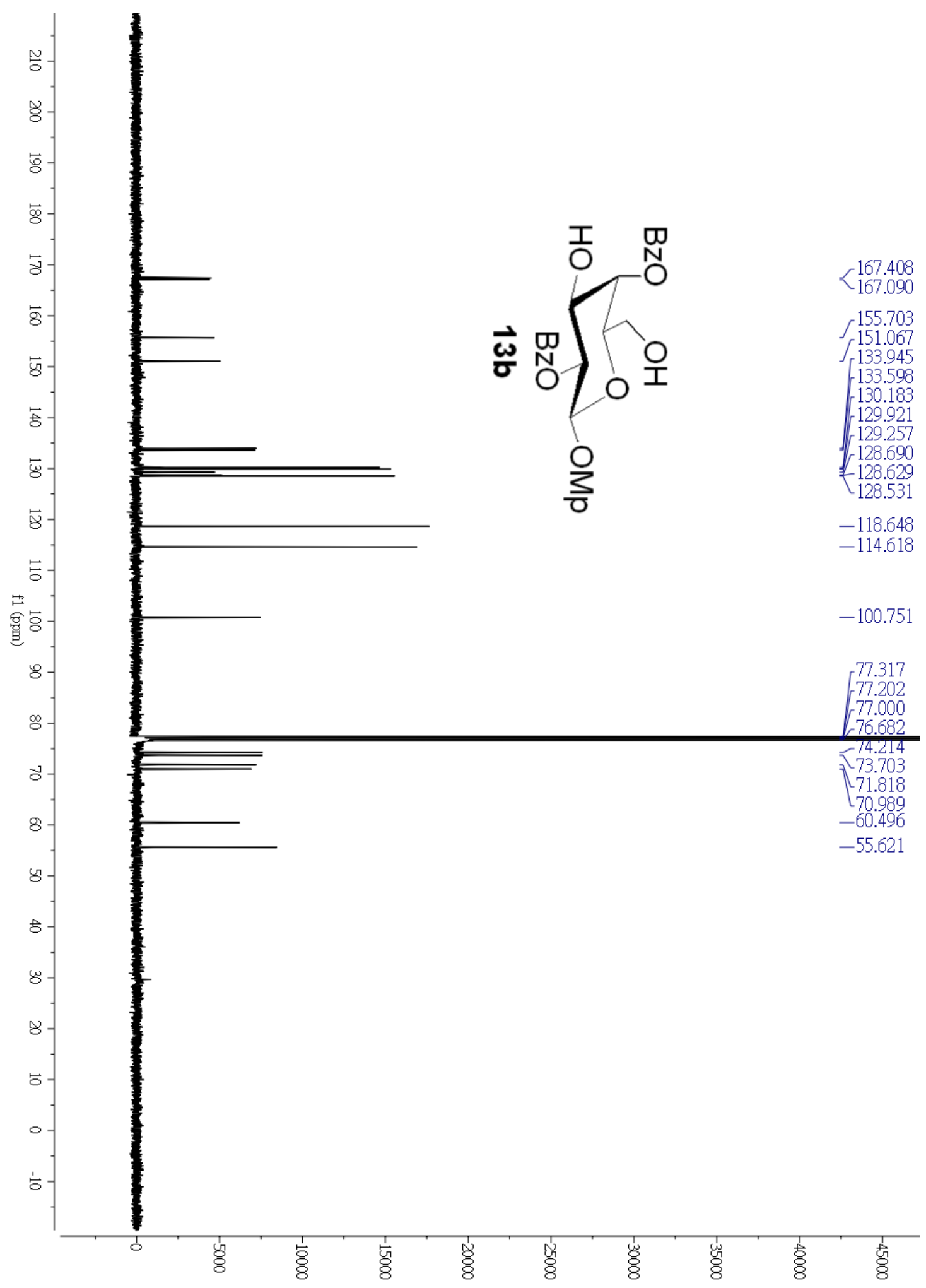

